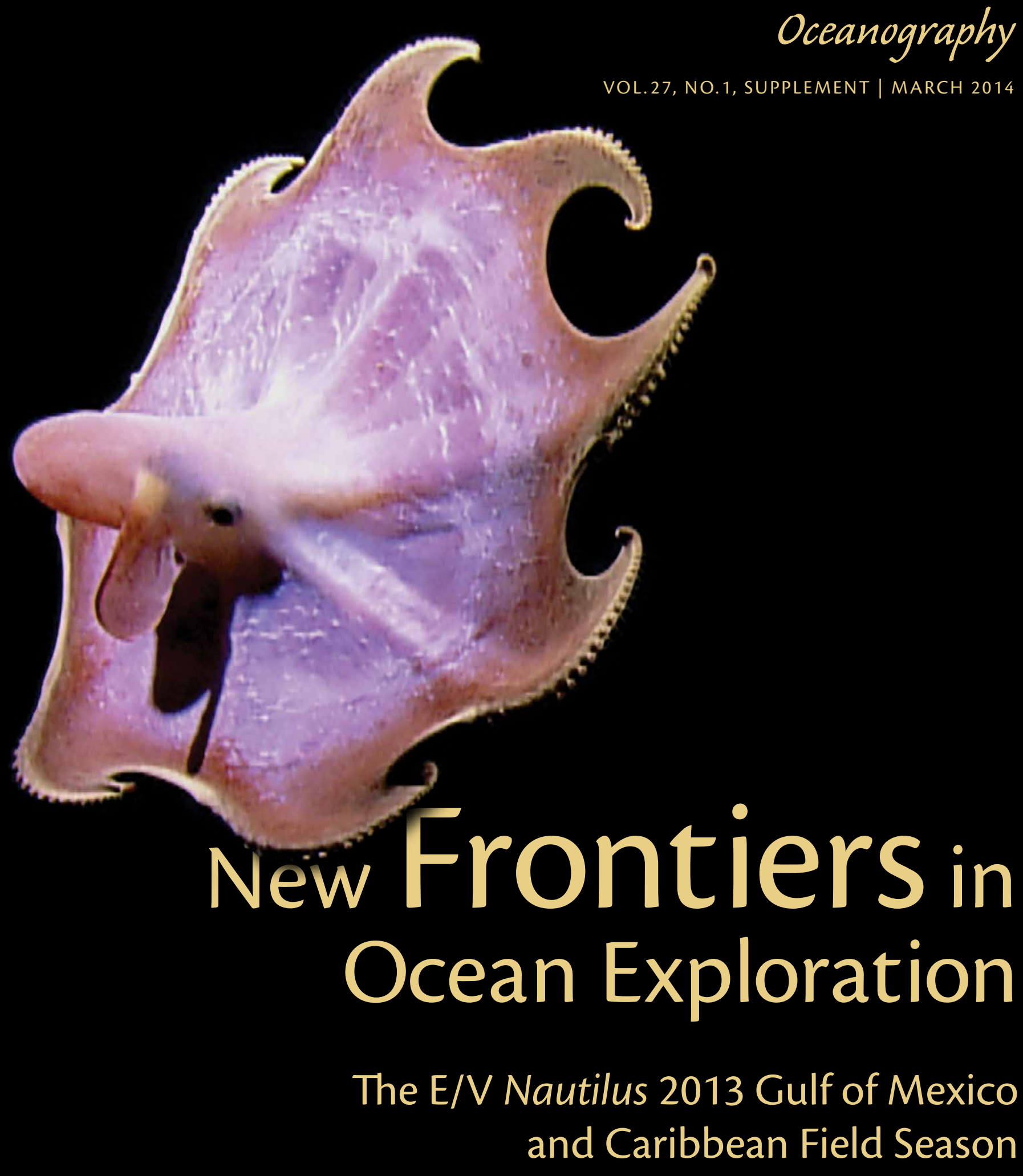

GUEST EDITORS | KATHERINE L.C. BELL, MICHAEL L. BRENNAN, AND NICOLE A. RAINEAULT 


\section{Contents}

FOREWORD 1

INTRODUCTION 2

TECHNOLOGY. 4

DATA MANAGEMENT 12

GEOLOGICAL AND BIOLOGICAL SAMPLE ARCHIVING .14

NAUTILUS EDUCATION PROGRAMS .16

THE NAUTILUS LIVE EXPERIENCE. .18

EXPLORATION NOW. .19

EXPANDING THE TELEPRESENCE PARADIGM

2013 FIELD SEASON SUMMARY.

.24

Sea Acceptance Trials of the Multibeam Echosounder and Subbottom Profiler.............................................................................26

Exploring Deep-Sea Coral Communities and the Effects of Oil and Gas Inputs to the Gulf of Mexico................................28

The Monterrey Wrecks: Characterization of Three Early $19^{\text {th }}$ Century Ships in the Gulf of Mexico......................................30

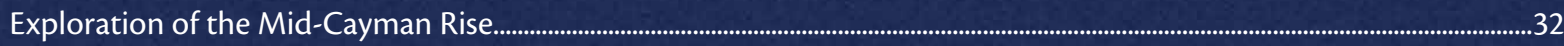

Earthquake, Landslide, and Tsunami Hazards and Benthic Biology in the Greater Antilles.......................................................34

Impact of Volcanic Eruptions on the Seafloor Around Montserrat, West Indies.........................................................................36

Fluid/Gas Venting and Biological Communities at Kick'em Jenny Submarine Volcano, Grenada (West Indies) ...............38

A Portable, Education-Focused Approach to Exploration in the Aegean Sea ............................................................................42

EPILOGUE . .44

AUTHORS .46

ACKNOWLEDGEMENTS

REFERENCES

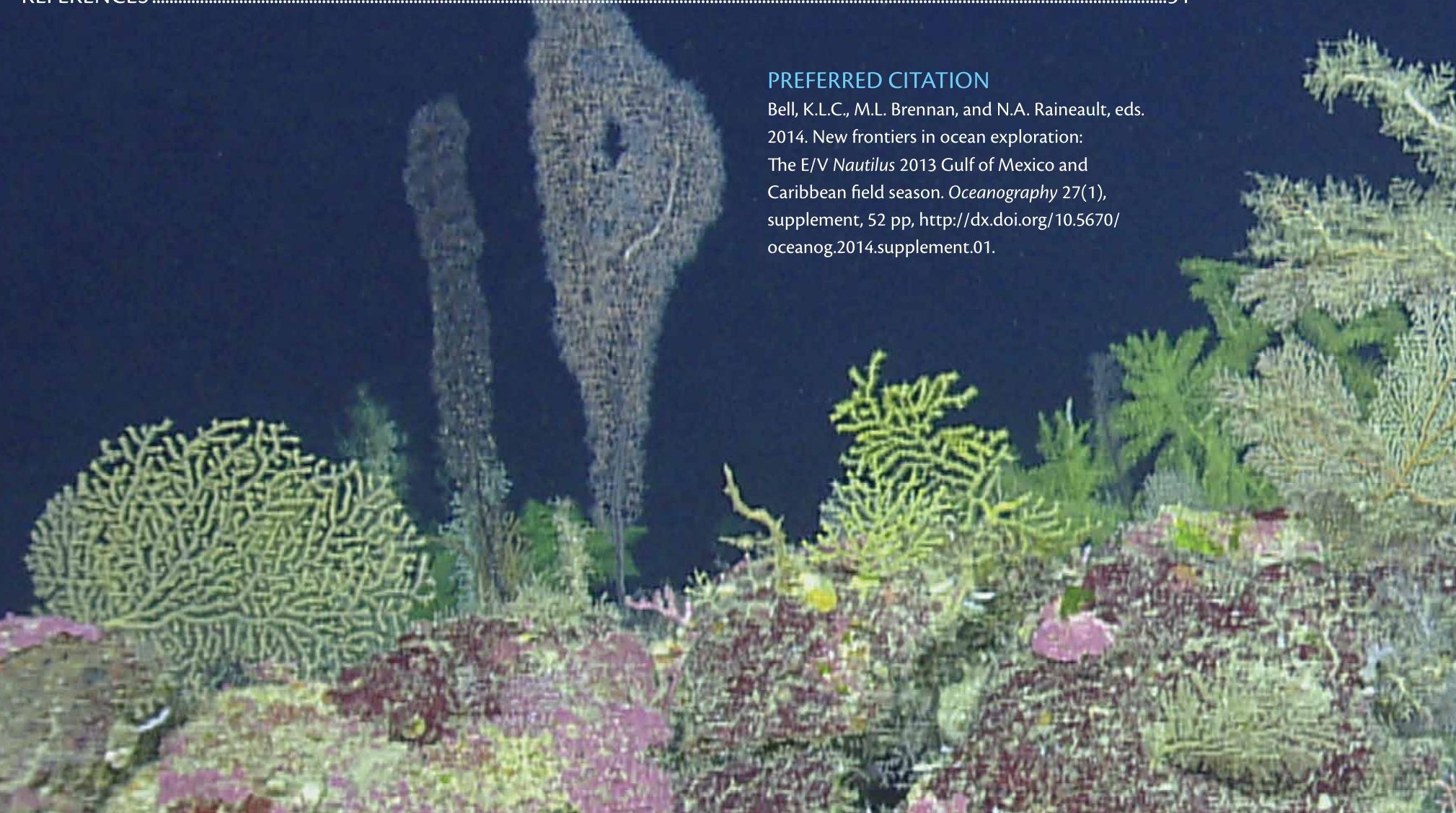




\section{FOREWORD Byrobert beallard}

Throughout the last five years of beaming real-time telepresence from Exploration Vessel (E/V) Nautilus, the Ocean Exploration Trust has had to rely upon other organizations to provide the bathymetric maps that are essential to locating promising sites for investigation with our remotely operated vehicle system. As a result, it has not been possible for the Nautilus Corps of Exploration to investigate remote regions of the world ocean where explorers have never before ventured.

That situation changed in the spring of 2013 when an international group of engineers from France, Canada, Turkey, and the United States teamed up with Kongsberg Maritime of Norway to install an EM302 $30 \mathrm{kHz}$ multibeam echosounder on the hull of Nautilus, along with other acoustic sensors. Nautilus returned to Çindemir Shipyard in Tuzla, Turkey, where its previous work had been done, for installation of these new systems. Next came a harbor acceptance test in the Sea of Marmara, followed by sea acceptance trials off Toulon, France. The results were better than expected: Gates Acoustic Services personnel, who evaluated the new systems, found the EM302 to be "an order of magnitude quieter" than similar sonars recently mounted on other research ships.

Following the acceptance trails in April, Nautilus crossed the North Atlantic Ocean, surveying Great Meteor Seamount along the way, to begin the 2013 field season in the Gulf of Mexico and the Caribbean Sea.

The major focus of the Nautilus 2013/2014 field program is to implement the recommendations of the Ocean Exploration Workshops conducted by the Trust with funding from the Richard Lounsbery Foundation, in collaboration with NOAA's Office of Ocean Exploration. We reported on the results of the Workshop on TelepresenceEnabled Exploration of the Caribbean Region in our last supplement to Oceanography (available at http://tos.org/ oceanography/archive/26-1_nautilus.pdf). The recommendations from this workshop were critical to the organization of our 2013 and 2014 field seasons, and it provided the engagement with the international oceanographic community needed to implement our programs. Participants' engagement in the process, from project planning to joining the exploratory expeditions and publishing results in peer-reviewed journals, has proven critical to our success.

This report summarizes our 2013 field season that began off Toulon in April and concluded at Kick'em Jenny submarine volcano, off Grenada, in November.

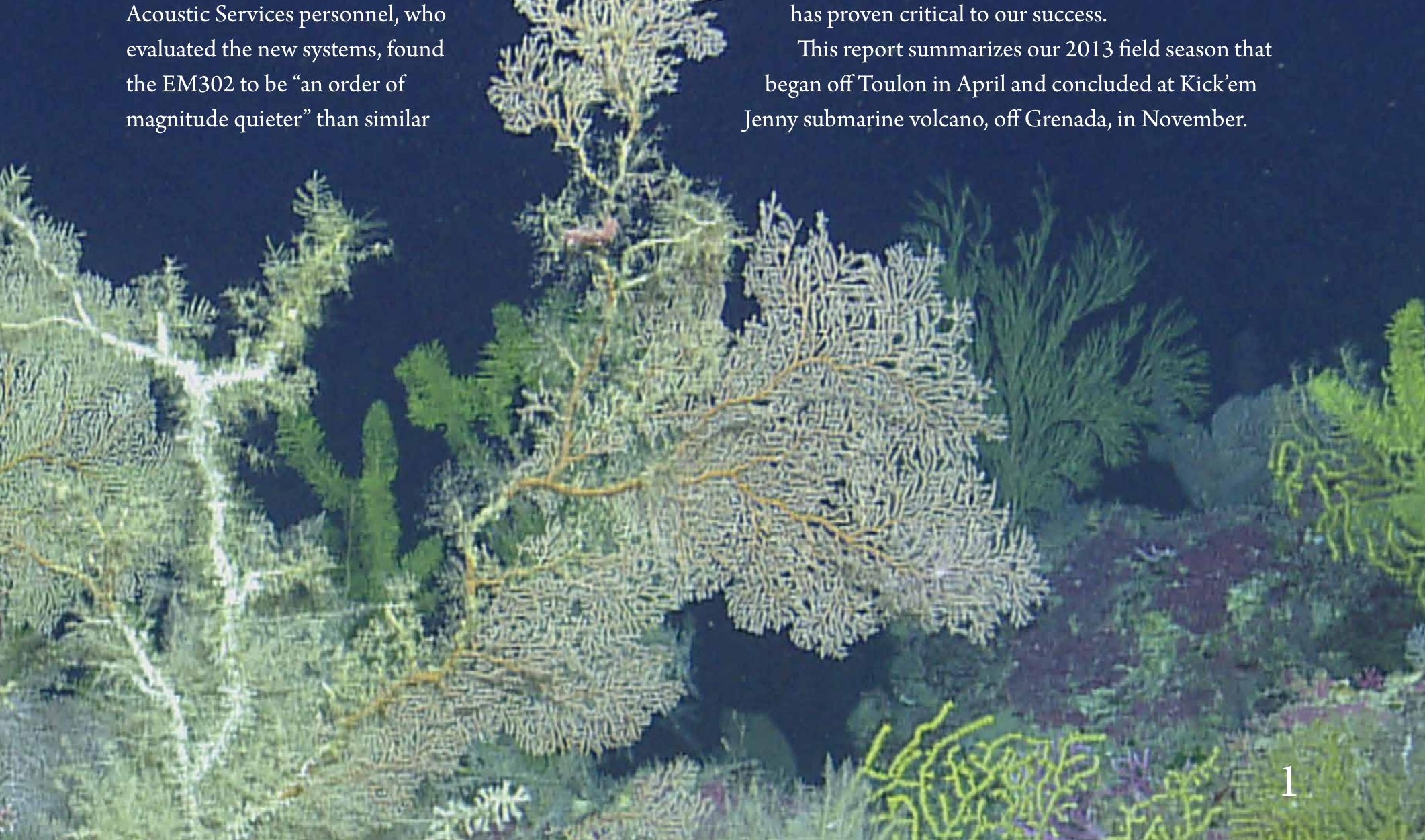




\section{INTRODUCTION}

The first E/V Nautilus season outside of the Mediterranean proved to be the most productive to date for the ship and its Corps of Exploration. This fourth Oceanography supplement chronicles the 2013 field season, from the installation of our new multibeam echosounder in Turkey to the $4 \frac{1}{2} 2$-month expedition in the Gulf of Mexico and the Caribbean Sea.

The first section of this supplement (pages 4-11) describes the ocean exploration technology on board Nautilus. Over the past five years, we have invested nearly $\$ 10$ million in improving the ship's capabilities and transforming Nautilus from an East German hydrographic vessel to a state-of-the-art ship of exploration. During 2013, we installed a Kongsberg EM302 multibeam echosounder that enables Nautilus to operate independently in unexplored regions of the global ocean. In 2014, we are completely renovating the Data Lab and Satellite Room to create a new Data Processing \& Visualization Laboratory in preparation for installation of a new Command Center in 2015-2016. Although we have several years and millions of dollars to go to finish the ship, Nautilus is rapidly becoming recognized by the oceanographic community as a valuable tool for research and exploration because of its combined capabilities - a new multibeam mapping system, remotely operated vehicles, and telepresence technology.
In the last year, the Nautilus data engineering and science teams have strengthened our ability to make both digital and physical data more widely available to the oceanographic community (pages 12-15). The second section focuses on these initiatives. It describes our emerging digital data systems and new partnerships with the Harvard Museum of Comparative Zoology and Northeastern University's Ocean Genome Legacy, which now allow us to make biological samples available to researchers all over the world. These new partnerships augment our relationship with the University of Rhode Island Marine Geological Samples Lab for archiving of and access to all of the Nautilus rock and core samples.

One of the main missions of the Ocean Exploration Trust (OET) is to use the excitement of exploration to inspire students to study science, technology, engineering, and math. Over the past five years, we have developed a range of education and outreach programs to fulfill that goal. During the 2013 season, 21 high school students, 25 educators, 16 undergraduate and graduate interns, and numerous scientists from 19 countries sailed on Nautilus through our education and partner programs (pages 16-17). Our outreach efforts continued to include a live, online presence; interactions with museums, aquariums, and science centers; and videography for a television special (pages 18-19). The Nautilus Live website (http://www.nautiluslive.org) streamed live from the seafloor, provided virtual explorers opportunities to participate in the expedition along with the shipboard team, as they answered thousands of questions that came in from viewers all over the globe. Nautilus Live was augmented by a new initiative, Exploration Now, that allows us to share not only Nautilus expeditions but also those of other telepresence-enabled vessels with museum audiences and online viewers. Finally, we also worked with the National Geographic Society to film four of our cruises in the Caribbean Sea for a one-hour television special scheduled to air on the National Geographic Channel in spring 2014.

In 2013, for the first time we equipped R/V Atlantis and 


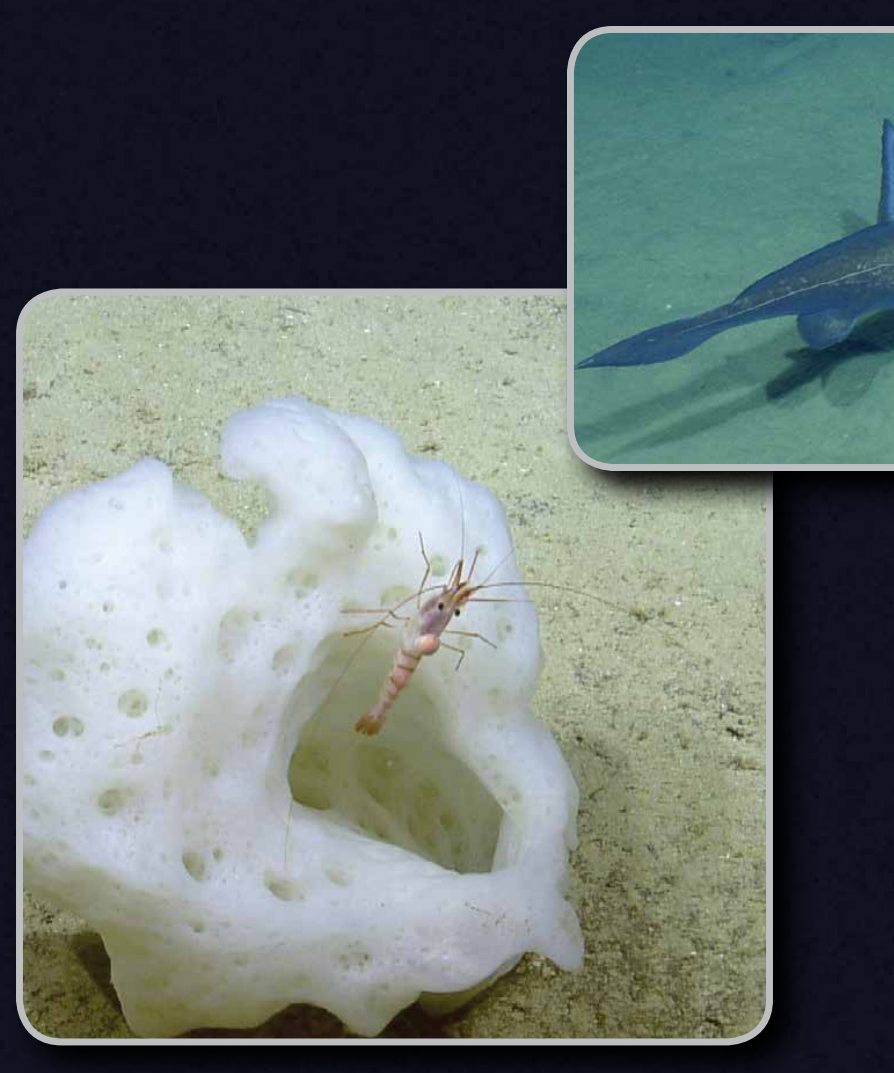

the Jason remotely operated vehicle (ROV) system with OET's "fly-away" telepresence system. Inner Space Center Director Dwight Coleman and scientists from two Atlantis cruises describe using telepresence primarily for education and outreach programs and the potential to support remote science from shore (pages 20-23). We look forward to working with ships in the US academic research fleet on the continued development and utilization of telepresence for remote science and education.

During 180 days at sea in 2013, the Nautilus Corps of Exploration collected nearly $25,000 \mathrm{~km}$ of new multibeam bathymetry data using new acoustic systems (pages 26-27). The ROV made 72 dives and spent over 890 hours in the water, including 728 hours ( $80 \%$ ) on the bottom making observations and physical measurements and collecting 656 rock, water, and biological samples that were sent to various repositories across the country and are now available to the oceanographic community. In addition to Nautilus data collection in the Caribbean region, in 2013 we mapped shipwrecks in the Aegean Sea with an AUV from STS Bodrum, continuing our long history of exploration in the region (pages 42-43).

This year was the first time Nautilus undertook a significant amount of "applied exploration," research funded and conducted by other organizations, with education and outreach conducted through OET's myriad programs. This supplement describes two of the applied exploration projects conducted in the Gulf

of Mexico. The first investigated the impacts of the 2010 Deepwater Horizon oil spill on the corals and other benthic organisms living in close proximity to the Macondo well (pages 28-29). The second began excavation of the Monterrey A shipwreck, an early nineteenth century vessel that sank nearly $200 \mathrm{~nm}$ off the coast of Galveston, TX, and discovered two nearby shipwrecks that date to around the same time period (pages 30-31).

Planning for the second, "basic exploration," half of the expedition was based on targets identified during our 2012 Workshop on Telepresence-Enabled Exploration of the Caribbean Region. In addition to the shipboard science parties, we had significant "Scientist Ashore" participation for the first time, with 162 shore-based scientists involved in our Caribbean exploration. We hope to see that number grow in 2014 and beyond. The first project took Nautilus to the Mid-Cayman Rise, where the team continued investigation of Mt. Dent, site of the discovery of a large hydrothermal vent system in 2010. The team also explored other "oceanic core complexes" along the Mid-Cayman Rise that had not previously been investigated (pages 32-33). In the fall, we explored the regional tectonics as well as benthic biological communities around Puerto Rico and the Virgin Islands (pages 34-35). We next headed south to the Lesser Antilles to examine the impacts of volcanic eruptions on the seafloor around Montserrat and Dominica (pages 36-37). The season ended off the coast of Grenada, where we studied the changes inside Kick'em Jenny submarine volcano since the last cruise there in 2003, and also discovered a series of cold seep communities located on the distal end of a massive underwater landslide deposit in the Grenada Basin, on the slope of Kick'em Jenny (pages 38-41). It was an unexpected and exciting end to a successful season, and we look forward to continuing our exploration of the Gulf of Mexico and Caribbean Sea in 2014. 


\section{TECHNOLOGY}

By Katherine L.C. Bell, Robert D. Ballard, Reuben Mills, Nicole Raineault, Ethan Gold, and Robert Knott

\section{History of Nautilus Improvements}

In 2008, the Ocean Exploration Trust acquired Exploration Vessel (E/V) Nautilus, formerly the East German hydrographic vessel Alexander von Humboldt. Since then, the Trust has made annual investments in upgrading the ship and its technology with a view toward transforming Nautilus into a state-of-the-art vessel of exploration.

So far, four phases of Nautilus improvements are complete. In 2009, the focus was to maintain the ship's certification as a research vessel. The second phase (2010-2011) outfitted the ship to operate our various undersea vehicles. Work included adding bow and stern thrusters coupled to a dynamic positioning system, a new A-frame, two generators, a launch and recovery crane, a new satellite system, and a new vehicle workshop. In 2011-2012, we completely renovated most of the social and living spaces aboard the ship to ensure that we could retain the amazing men and women who comprise our Corps of Exploration. Work included upgrading the galley, the mess deck, the lounge, and several exterior social spaces; securing a new waste management plant; installing new heads/showers; and increasing the capacity of the air conditioning system, among other improvements. In 2012-2013, we installed a nine-ton Kongsberg EM-302 multibeam echosounder system on the hull of the ship. The multibeam proved to be highly successful, making Nautilus a truly independent exploration platform, as we can now make our own bathymetric maps in unexplored regions of the world.
In 2013-2014, we began the fifth phase of Nautilus improvements, renovating more than 1,850 square feet of working space throughout the vessel. This phase is expected to take two to three years because of the expenses involved. So far, we have completely renovated the Data Processing \& Visualization Lab, Electronics Rack Room \& Workshop, and theater space, which will temporarily house the Production Studio. In late 2014 and beyond, we will replace the Command Center on the bridge deck, expanding it by $60 \%$ and incorporating the Production Studio, which until now has been located in temporary spaces on the ship. We also plan to enhance existing living spaces and construct new ones.

The sixth and final phase of improvements for Nautilus will focus on performance, safety, and redundancy, with emphasis on the engine room and the satellite link to shore-key elements to our program when we begin operating in some of the most remote regions of the world where we will be truly on our own. 


\section{Exploration Vessel Nautilus}

BUILT | 1967, Rostock, Germany

LENGTH | 64.23 meters (211 feet)

BEAM | 10.5 meters ( 34.5 feet)

DRAFT | 4.9 meters (14.75 feet)

TONNAGE | 1,249 gross, 374 net

RANGE | 24,000 kilometers (13,000 nautical miles)

ENDURANCE | 40 days at sea

SPEED | 10 knots service, 12 knots maximum

FUEL CAPACITY | 330 cubic meters

PROPULSION | Single 1,286 kilowatt (1,700 hp) controllable pitch main thruster; $250 \mathrm{~kW}$ bow thruster; $350 \mathrm{~kW}$ jet pump stern thruster
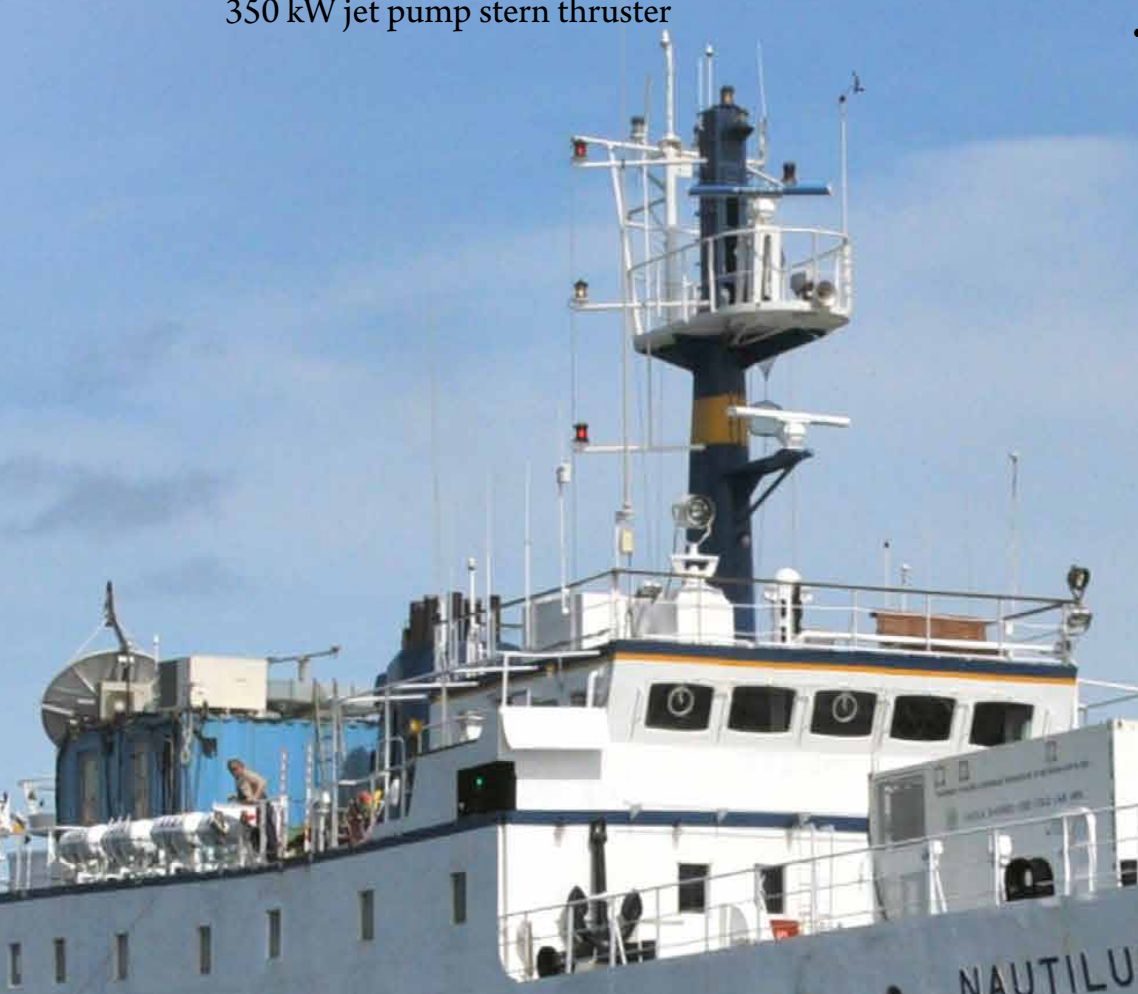

(1) 0

II
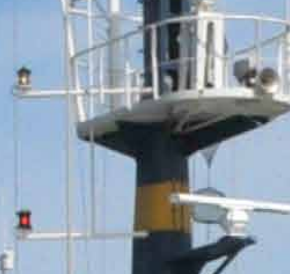

iin
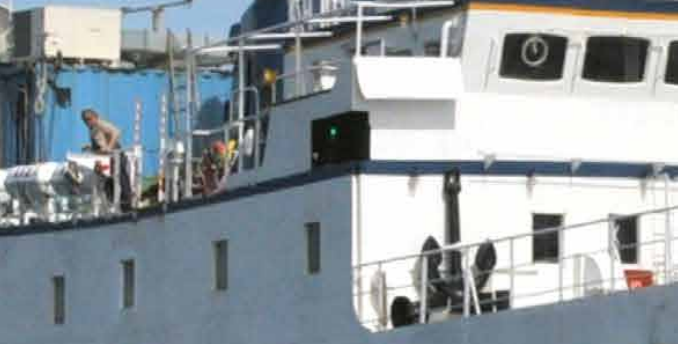

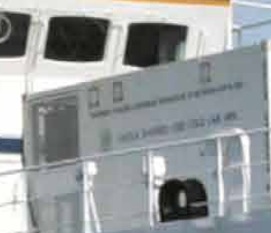

- NAUTILUS

1

1 one $350 \mathrm{kVa}$ generator, and one $450 \mathrm{kVa}$ shaft generator

PORTABLE VAN SPACE | One 20-foot van

COMPLEMENT | 17 crew; 31 science and operations

FLAG | St. Vincent and the Grenadines

HEAVY EQUIPMENT |

- Dynacon 421 ROV winch with 4,300 meter

(14,108 feet) Rochester A307573 1.73 centimeter (0.68 inch) diameter cable

- DT Marine 210 winch with $1,200 \mathrm{~m}$ Rochester A320327 0.82 centimeter ( 0.322 inch) diameter wire

- Hatlapa hydrographic winch

- Bonfiglioli knuckle-boom crane, 4.2 ton capacity, two extensions

- A-frame, 6 ton capacity

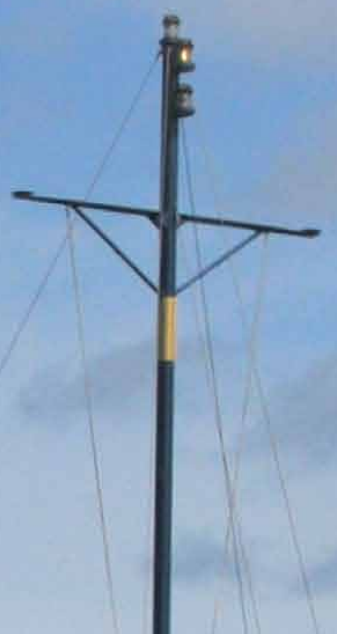




\section{TELEPRESENCE TECHNOLOGY}

VSAT | 2.4 meter tracking ELSP antenna capable of up to $20 \mathrm{Mbps}$ (C-band circular or linear)

\section{REAL-TIME VIDEO STREAMING |}

- Four Tandberg standard definition encoders with multiplex for encapsulating real-time video

- Harmonic Electra 7000 high definition encoder

CAMERAS | One Sony BZR-800 high definition pan/tilt/ zoom camera mounted in the Control Van and on the aft deck; one Marshall Electronics VS-570-HDSDI high definition camera with pan/tilt/zoom, and microphone for interaction with shore, mounted in Wet Lab and ROV hangar

\section{COMMUNICATIONS |}

- Ship-wide RTS Telex intercom system for real-time communications between ship and shore

- Handheld UHF radios are interfaced with the RTS intercom system for deck, bridge, and Control Room communications

\section{DATA PROCESSING \& VISUALIZATION LAB}

AREA | 44.5 square meters ( 480 square feet)

WORKSTATIONS | Seven workstations for data manager, data loggers, navigators, educators, data engineers, satellite engineer, video engineer; high-resolution map, multibeam, and side-scan sonar processing; flexible bench space

\section{CONTROL \& IMAGING VANS}

AREA | 28 square meters (301.4 square feet)

WORKSTATIONS | Nine; typical configuration for ROV operations: two to three scientists, data logger, Hercules pilot, Argus pilot, navigator, video engineer, educator

\section{RACK ROOM}

AREA | 17.3 square meters (185 square feet)

VIDEO STORAGE | Two Omneon Mediadecks

(MDM- 5321 and SMD-2200-BB) for video recording, playback, and storage

DATA STORAGE | 5 TB online storage for non-video data; $28 \mathrm{~TB}$ disk storage for video data

\section{EMERGENCY COMMUNICATIONS | Electronics} workbench

IONS | Iridium phone

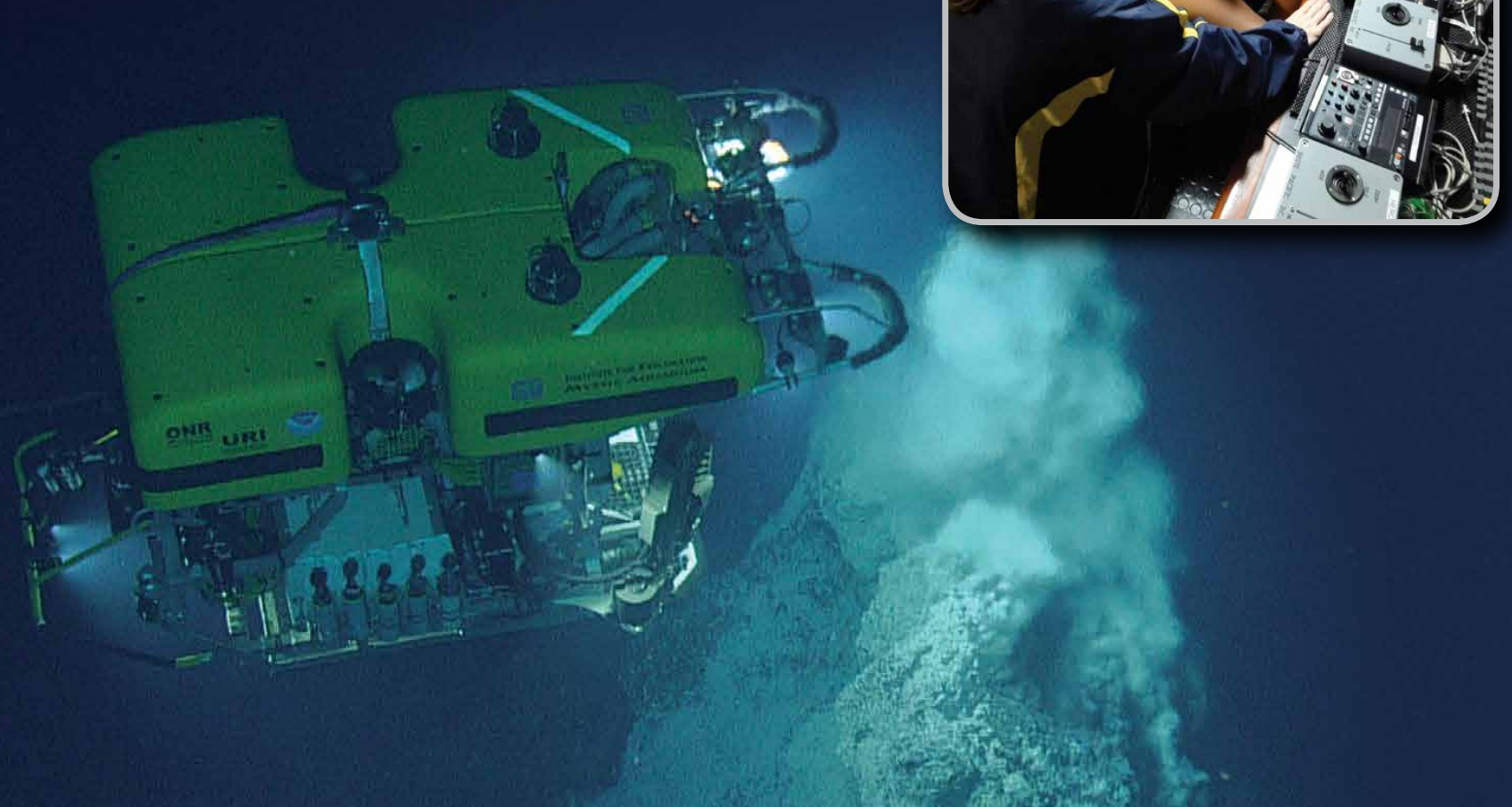




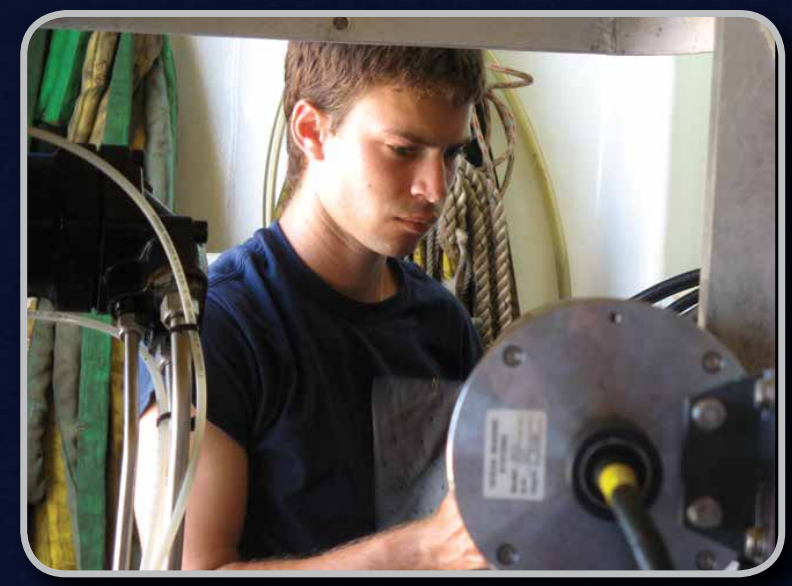

\section{WET LAB}

AREA | 19 square meters (204.5 square feet) with

5-meter-long (16-foot) stainless steel worktop

\section{REFRIGERATION |}

- Panasonic MDF-C8V1 ULT $-80 /-86^{\circ} \mathrm{C}$ scientific freezer, 0.085 cubic meters ( 3 cubic feet)

- Science refrigerator/freezer, approximately 0.57 cubic meters ( 20 cubic feet)

- ThermoSafe 560 dry ice machine

\section{MICROSCOPE |}

- Nikon SMZ800 trinocular microscope, $6.3 \times$ zoom, Vari-Mag C-mount camera adapter with additional $2.5 \times$ ocular

- Dual output cold light source

- Nikon D300 SLR camera

- HDMI out for sharing microscope video with shore

\section{HAZMAT |}

- Fume hood

- HAZMAT locker for chemical and waste storage

- Carry-on, carry-off chemical policy

\section{PRODUCTION STUDIO}

AREA | 12 square meters (130 square feet)

CAMERA | Remote controllable high definition Sony BRC-H700

SWITCHER | Ross CrossOver16 with ability to switch underwater, topside, or scaled computer video streaming to the Inner Space Center for live interactions

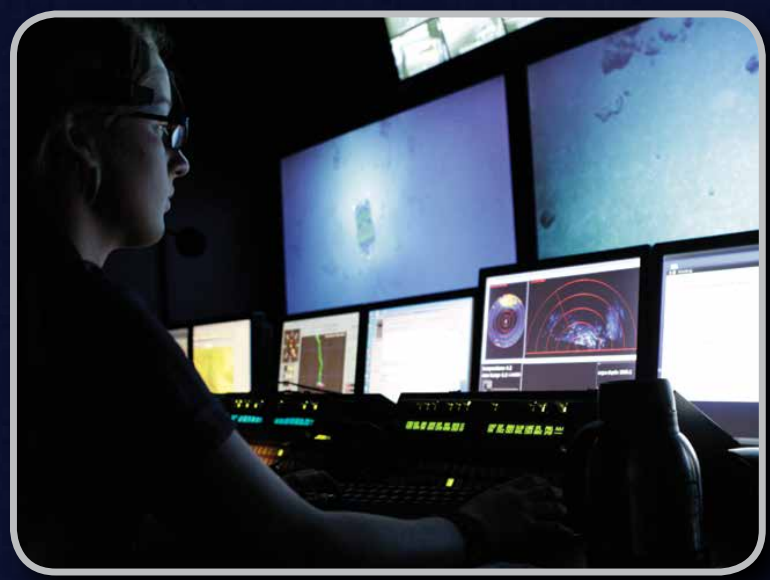

ROV HANGAR

AREA | 24 square meters (258.3 square feet)

POWER | $110 / 60 \mathrm{~Hz}$ and $220 / 50 \mathrm{~Hz}$ available

PERSONAL PROTECTIVE EQUIPMENT | Hard hats, PFDs, high voltage gloves

LIFTS | $2 \times 2$-ton overhead manual chainfall lifts

STORAGE | Storage for spares and other equipment

\section{ROV WORKSHOP}

AREA | 18 square meters (193.8 square feet)

TOOLS | Complete set of hand tools, cordless tools, electrical and fiber optic test equipment, mill-drill combination machine

STORAGE | Storage for spares and other equipment 


\section{Acoustic Systems}

\section{KONGSBERG EM302}

\section{MULTIBEAM ECHOSOUNDER}

FREQUENCY | $30 \mathrm{kHz}$

DEPTH RANGE | 10-7,000 meters (33-22,966 feet)

SWATH WIDTH | Up to 5.5 times water depth, to approximately 8,000 meters (26,247 feet)

PULSE FORMS | CW and FM chirp

BEAMWIDTH $\mid 1^{\circ} \times 1^{\circ}$

APPROXIMATE SWATH WIDTH | 3-5 $\times$ water depth, up to $8 \mathrm{~km}$

APPROXIMATE GRID RESOLUTION | 10\% water depth (e.g., $10 \mathrm{~m}$ at $1,000 \mathrm{~m}$ depth)

\section{KNUDSEN SUBBOTTOM PROFILER AND ECHOSOUNDER}

PROFILER | Knudsen 3260 Chirp subbottom profiler and echosounder

OPERATING FREQUENCY | Dual frequency, $3.5 \mathrm{kHz}$ and $15 \mathrm{kHz}$

POWER | $4 \mathrm{~kW}$ on Channel 1 and up to $2 \mathrm{~kW}$ on Channel 2

RANGE | 50 to 5,000 meters (164 to 16,404 feet)

\section{ULTRA-SHORT BASELINE} NAVIGATION SYSTEM

SYSTEM | TrackLink 5000MA system for USBL tracking of ROVs Hercules and Argus

RANGE | Up to 5,000 meters (16,404 feet)

POSITIONING ACCURACY | $1^{\circ}$ (better than $2 \%$ of slant range)

OPERATIONAL BEAMWIDTH | $120^{\circ}$

OPERATING FREQUENCY | 14.2 to $19.8 \mathrm{kHz}$

TARGETS TRACKED | Up to eight

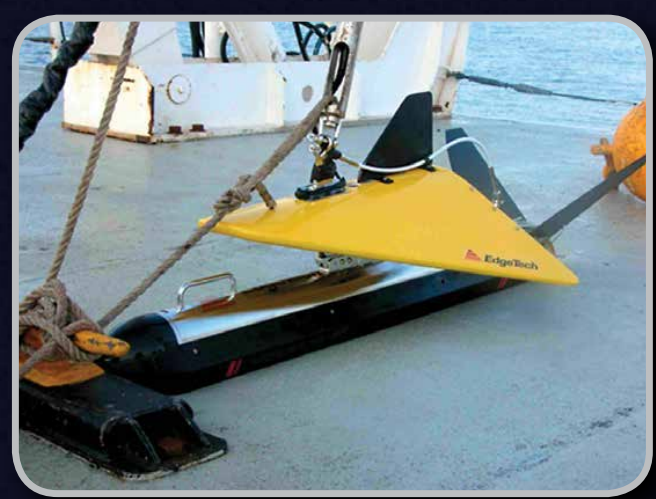

\section{SIDE-SCAN TOWFISH DIANA}

SIDE-SCAN SONAR | EdgeTech 4200 MP CHIRP side-scan sonar with depressor wing

DEPTH CAPABILITY | 2,000 meters (6,561.7 feet), currently limited by 1,000 meter (3,280.8 foot) cable

TOWFISH SIZE $\mid 125.6$ centimeters $\times 11.4$ centimeters (49.5 inches $\times 4.5$ inches)

FREQUENCY | 300 and $600 \mathrm{kHz}$ dual simultaneous OPERATING RANGE | 230 meters $(300 \mathrm{kHz})$, 120 meters $(600 \mathrm{kHz})$

HORIZONTAL BEAMWIDTH $\mid 0.54^{\circ}$ and $0.34^{\circ}$ (high speed mode), $0.28^{\circ}$ and $0.26^{\circ}$ (high definition mode)

VERTICAL BEAMWIDTH | 50

DEPRESSION ANGLE | Tilted down $20^{\circ}$

RESOLUTION ALONG TRACK (HIGH SPEED MODE) | 300 kHz: 1.9 meters@ 200 meters; 600 kHz: 0.6 meters@ 100 meters

RESOLUTION ALONG TRACK (HIGH DEFINITION MODE) | 300 kHz: 1.0 meter @ 200 meters; 600 kHz: 0.45 meters@ 100 meters

RESOLUTION ACROSS TRACK | 3 centimeters $(300 \mathrm{kHz}), 1.5$ centimeters $(600 \mathrm{kHz})$

SENSORS | Heading, pitch, roll, pressure 


\section{Remotely Operated Vehicle Argus}

\section{GENERAL}

DEPTH CAPABILITY | 6,000 meters (19,685 feet), currently limited to 4,000 meters

CABLE | 4,000 meters, 0.681 electro-optical, $3 \mathrm{x} \# 11$ conductors, $3 \mathrm{x}$ SM fibers

SIZE | 3.8 meters long $\times 1.2$ meters wide $\times 1.3$ meters high

WEIGHT | 1,800 kilograms (4,000 pounds)

MAXIMUM TRANSIT SPEED | 2 knots

ASCENT/DESCENT RATE | 30 meters/minute (98.4 feet/minute)

PROPULSION | Two Deep Sea Systems International 404 brushless DC thrusters for heading control

\section{IMAGING \& LIGHTING}

\section{CAMERAS |}

- One Insite Pacific Zeus Plus high definition camera with Ikegami HDL-45A tilt head with Fujinon HA 10×5.2 lens -1080i SMPTE 292M output format 2 MP still image capable

- Three Insite Pacific standard definition mini utility cameras (fixed mounted) 480 line NTSC format

- One Insite Pacific low-light "fish-eye," downwardlooking standard definition camera (fixed mounted)

\section{LIGHTING |}

- Two Deep Sea Power \& Light 1,200 Watt HMI, 100,000 lumens each

- Two Deep Sea Power \& Light 400 Watt HMI

- Two Deep Sea Power \& Light 250 Watt Incandescent

\section{VEHICLE SENSORS \& NAVIGATION}

USBL NAVIGATION | TrackLink 5000 system, acoustically triggered

PRIMARY HEADING | Crossbow high resolution magnetic motion and attitude sensor

SECONDARY HEADING | TCM2 solid state fluxgate compass

PRESSURE SENSOR | Paroscientific Digiquartz 8CB series

ALTIMETER | Benthos PSA-916

FORWARD-LOOKING SONAR | Mesotech 1071, $675 \mathrm{kHz}, 100$ meters range

SIDE-SCAN SONAR | EdgeTech $4200 \mathrm{MP}$

SUBBOTTOM PROFILING SONAR | TriTech SeaKing Parametric Subbottom Profiler $(10-30 \mathrm{kHz})$

\section{SCIENTIFIC INSTRUMENT SUPPORT}

POWER | 110 V $60 \mathrm{~Hz}$ AC, 24 VDC, 12 VDC, 5 VDC power options

DIGITAL DATA CHANNELS | Three RS-232, one 100base-T Ethernet 


\section{Remotely Operated Vehicle Hercules}

\section{GENERAL}

\section{DEPTH CAPABILITY | 4,000 meters (13,123 feet)}

TETHER | 30-45 meters (98.4-147.6 feet), 20 millimeters (0.79 inches) diameter, neutrally buoyant

SIZE | 3.9 meters long $\times 1.9$ meters wide $\times 2.2$ meters tall $(12.8$ feet long $\times 6.2$ feet wide $\times 7.2$ feet tall $)$

MASS | 2,500 kilograms (5,500 pound-mass) in air

MAXIMUM VEHICLE SPEED 0.77 meters/second ( 1.5 knots) forward, 0.25 meters/second ( 0.5 knots) lateral, 0.5 meters/second ( 1 knots) vertical (on site, within tether range)

MAXIMUM TRANSIT SPEED | 1 meter/second (2 knots), no sampling, in layback mode

\section{MAXIMUM ON-BOTTOM TRANSIT SPEED |}

0.5 meters/second ( 1 knot), no sampling

MAXIMUM SAMPLING TRANSIT SPEED | 0.25 meters/ second ( 0.5 knots) on flat seafloor; $<0.13$ meters/ second $(<0.25$ knots $)$ over featured terrain

\section{ROV CLOSED LOOP POSITION CONTROL | Station}

Keep, X/Y step, Auto Depth, Auto Altitude, X/Y/Z step and hold velocity control

DESCENT/ASCENT RATE | 30 meters/minute (98.4 feet/minute)

\section{PROPULSION |}

- Six hydraulic thrusters powered by $15 \mathrm{~kW}(20 \mathrm{hp})$, 207 bar (3,000 psi) hydraulic system

- Fore/Aft \& Vertical - Four $27.94 \mathrm{~cm}$ (11 inch) ducted thrusters, each providing $900 \mathrm{~N}$ (200 lbf) thrust

- Lateral - Two $22.86 \mathrm{~cm}$ (9 inch) ducted thrusters, each providing $450 \mathrm{~N}(100 \mathrm{lbf})$ thrust

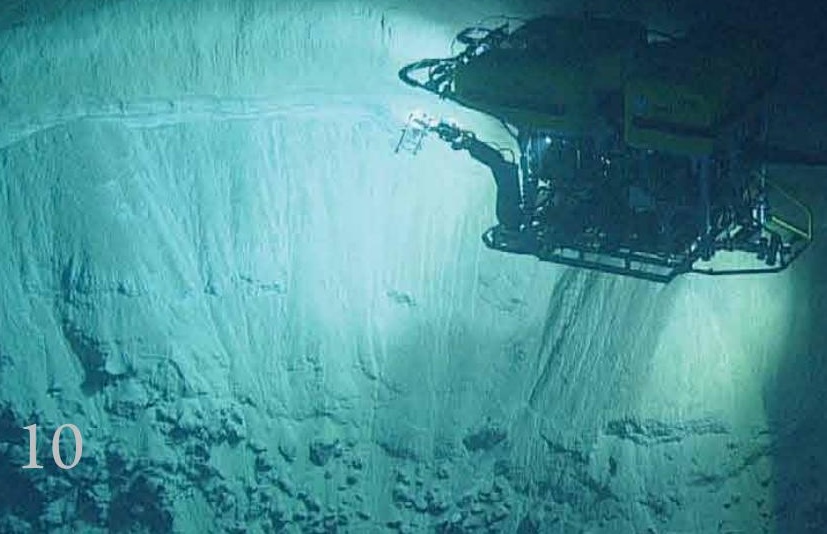

\section{VEHICLE SENSORS \& NAVIGATION}

\section{HEADING AND ATTITUDE |}

- Primary Heading - IXSEA Octans III north-seeking fiber-optic gyrocompass $\left(0.1^{\circ}\right.$ secant latitude accuracy with $0.01^{\circ}$ resolution)

- Secondary Heading - TCM2 solid state fluxgate compass

PRESSURE SENSOR | Paroscientific Digiquartz 8CB series

CTD | Seabird FastCAT 49

OXYGEN OPTODE | Aanderaa 3830

TEMPERATURE PROBE | WHOI high temperature probe $\left(0^{\circ}-450^{\circ} \mathrm{C}, .1^{\circ} \mathrm{C}\right.$ resolution $)$

\section{USBL NAVIGATION | LINKQUEST TrackLink 5000}

DOPPLER NAVIGATION \& ALTITUDE | RDI Workhorse

Navigator Doppler Velocity Log 600 kHz, 0.7-90 meter range (2.3-295.3 feet)

\section{FORWARD-LOOKING SONARS |}

- Kongsberg Mesotech 1071 profiling sonar, $300 \mathrm{kHz}$, 200 meter range (164 feet)

- TriTech Super SeaPrince 675 kHz, 50 meter range (164 feet)

\section{IMAGING \& LIGHTING}

STANDARD IMAGING SUITE | One high definition video channel on fiber optic, four standard definition video channels on coax, generally configured as:

- Insite Pacific, 6,000 msw rated, Zeus Plus with 10x zoom lens, Ikegami HDL-45A with zoom/pan/tilt/ extend -1080i SMPTE 292M output format

- Insite Pacific, 6,000 msw rated, Titan Rotate-Tilt standard definition camera (bubble camera) 480 line NTSC format

- Three Insite Pacific NOVA utility cameras, mounted to view the starboard sample box, 480 line NTSC format

- One Insite Pacific Aurora utility camera, NTSC format

LIGHTING |

- Two Deep Sea Power \& Light 400 Watt HMI with dual-ballast, 12,000 lumens, forward mounted

- Two Deep Sea Power \& Light Matrix-3 LED lamps, 20,000 lumens, forward mounted

- Six to twelve Deep Sea Power \& Light Sphere LED lamps, 6,000 lumens mounting configurable 
SCALING | Two red Deep Sea Power \& Light Micro Sea-Lasers, mounted $10 \mathrm{~cm}$ (3.94 inches) apart, HD camera only

\section{HIGH-RESOLUTION MAPPING SUITE |}

- Available for nonstandard mapping products

- Typical configuration is downward looking; custom configurations possible

- $1375 \mathrm{kHz}$ BlueView multibeam, $90^{\circ}$ total swath, 30 meter range, centimeter resolution capable

- Two stereo Prosilica still cameras, one black \& white, one color; $1,024 \times 1,360$ pixels; $29^{\circ} \times 39^{\circ}$ field of view; strobe lighting

- Green laser sheet with dedicated laser camera; 532 nanometers; $100 \mathrm{~mW}$; $45^{\circ}$ line generating head; inclined plane

- Raytrix R5 lightfield camera

\section{MANIPULATORS AND SAMPLING}

\section{MANIPULATORS |}

- Kraft Predator: Hydraulic, seven function spatially correspondent, force feedback, $200 \mathrm{lb}$ lift

- ISE Magnum: Hydraulic, seven function, $300 \mathrm{lbs}$ lift

\section{SUCTION SYSTEMS |}

- Suction sampling system, two $\times 8$ liter discrete samples

- Jet-suction excavation system

SAMPLING TOOLS | Mission configurable

- Up to eight 6.35 centimeter ( 2.5 inch) inner diameter, 28 centimeter ( 11 inch) long push cores

- Up to six 5 liter Niskin bottles, manually triggered

- Custom tools can be integrated with prior notice

\section{SAMPLE STORAGE |}

- Forward sample tray (inboard): $45 \mathrm{~cm} \times 33 \mathrm{~cm} \times$ $25 \mathrm{~cm}$ (17.7 inches $\times 13$ inches $\times 9.8$ inches)

- Forward sample tray (outboard): $68 \mathrm{~cm} \times 35 \mathrm{~cm} \times$ $30 \mathrm{~cm}$ (26.8 inches $\times 13.8$ inches $\times 11.8$ inches)

- Starboard sample drawer: $65 \mathrm{~cm} \times 50 \mathrm{~cm} \times 30 \mathrm{~cm}$ (25.5 inches $\times 19.7$ inches $\times 11.8$ inches)

- Payload: Up to $300 \mathrm{lbs}$ depending on sensor package

- Custom configuration of boxes, crates, and containers

ELEVATORS | Mission configurable; free ascent; maximum standard payload $70 \mathrm{~kg}(150 \mathrm{lb})$

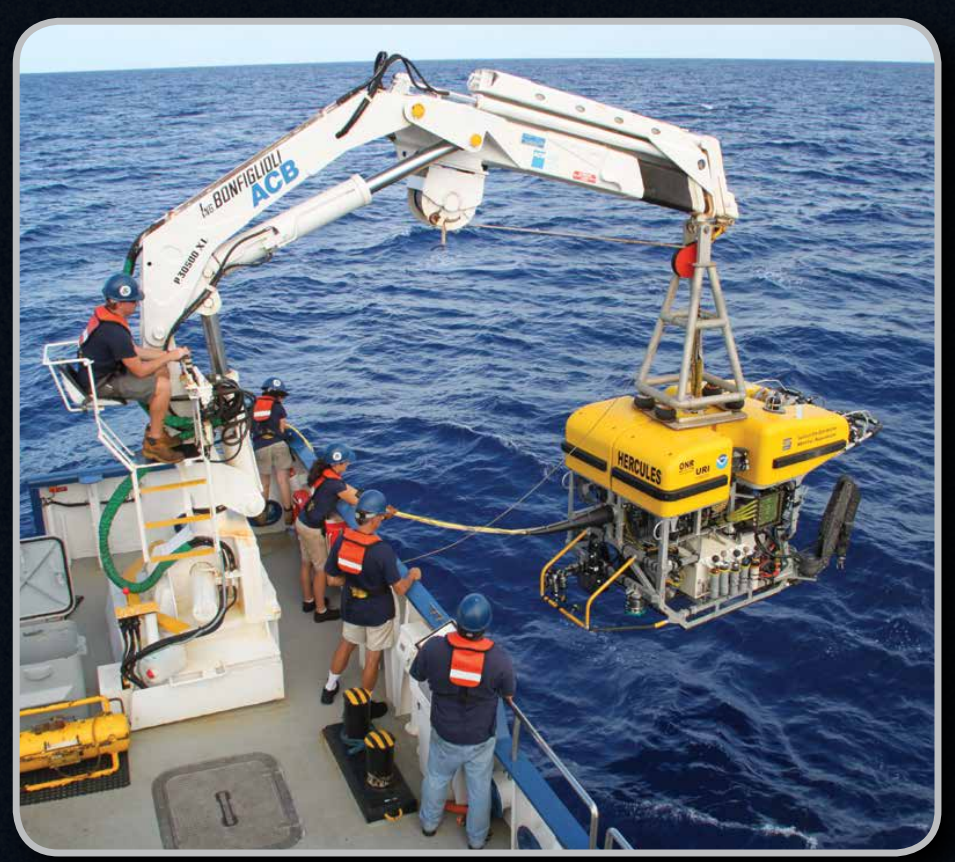

\section{SCIENTIFIC INSTRUMENT SUPPORT}

\section{SWITCHED POWER |}

- $110 \mathrm{~V}, 60 \mathrm{hz}$ AC

. $24 \mathrm{VDC}$

- $12 \mathrm{VDC}$

$.5 \mathrm{VDC}$

\section{DIGITAL DATA CHANNELS |}

- RS-232: 115 Kbauds

- RS-485/422: 2.5 Mbauds

- Ethernet: 10/100/1,000 mbps links available

- TTL: one TTL link

HYDRAULIC | Proportional and solenoid

hydraulic functions

- 1,150 psi at $10 \mathrm{GPM}$

- 1,850 psi at $10 \mathrm{GPM}$

-3,000 psi at 10 GPM (advance notice needed)

\section{EXAMPLES OF USER-INSTALLED SENSORS |}

- Harvard in situ mass spectrometer

- Fluorometer

- $\mathrm{pH}$ sensor

- PMEL MAPR eH sensor

- Kongsberg M3 multibeam sonar

- 18MP Ethernet connected digital still camera 


\title{
DATA MANAGEMENT
}

\author{
By Ethan Gold, Robert Knott, and Nicole A. Raineault
}

Digital and video data collected aboard Nautilus are essential to a successful expedition. Oceanographic sensor data, video and images, observational notes, and navigation form the scientific legacy of the Nautilus Exploration Program. In order to meet scientific, educational, and outreach goals, data accessibility both during and after an expedition is a high priority, and so it is continually being improved.

\section{Digital Data}

Digital data management on board Nautilus can be subdivided into four categories: (1) acquisition, (2) aggregation, (3) duplication, and (4) archiving and distribution.

Computers directly attached to instruments acquire data. Such computers may log data locally, distribute them over the network, or both. Often, specialized or proprietary third-party software is required for data acquisition. Data are acquired exclusively on the instrument network (Figure 1), which is segregated from the general user networks and the Internet. These systems only perform logging or real-time operational tasks. Usually, log files are written to local storage.

Aggregation is the process of assembling the instrument-specific data into a complete, organized context. A server that straddles the data and instrument networks periodically, usually every 15 minutes, synchronizes the logged data from the various acquisition machines into a structured hierarchy on a RAID (Redundant Array of Independent Disks). This location is the first to show a complete view of the work in progress. Data are organized by cruise (e.g., NA038, NA039), state (e.g., raw or processed), and type (e.g., navigation, event, acoustic).
The duplication step synchronizes the aggregate onto three to four rugged external hard drives on a per-cruise basis. The duplication step also runs incrementally with aggregation, so the copies are all updated every 15 minutes. At the end of the cruise, each drive is handed off to different carriers. One drive is retained aboard Nautilus for safe keeping and future reference, one drive is hand-carried to the Inner Space Center for archiving and distribution, one drive is given to the Lead Scientist for the cruise leg, and the last drive is delivered to the host country, if we are working in foreign waters.

Archiving and distribution can happen in two places. Aboard Nautilus, data are available within 15 minutes in a read-only folder from the aggregation server over the data network. From this point, several processing steps may begin, video stills can be accessed, and any other non-logging procedures can be applied. Data network users have easy access through standard file-sharing protocols and the local web server.

The focus of 2013 was on aggregation and duplication. In 2014, we plan to automate several manual reporting processes between the aggregation and duplication steps in order to improve near-real-time access to data for unified situational awareness and to expand the infrastructure behind shore-based archiving and delivery. 


\section{Video Data}

Video is copied from the internal storage RAID of the video servers daily, even if the vehicles are diving and content is currently being ingested. The video servers on Nautilus are capable of up to four channels of simultaneous video recording and playback per chassis, so there is no conflict with video clips being transferred to the data archive LTO6 tape drives while we are actively ingesting video from the vehicles. However, the video server creates empty clip files prior to actually recording video. At midnight UTC, we begin archiving the previous day's files, ensuring we are only archiving valid clips containing video files. The archive tapes are quality checked on board the ship after they are finalized, but the six terabytes of internal storage on each of our two server chassis usually affords the opportunity to check the validity of the archived video once it is received at the Inner Space Center before removing the files from our internal RAID storage on board Nautilus.

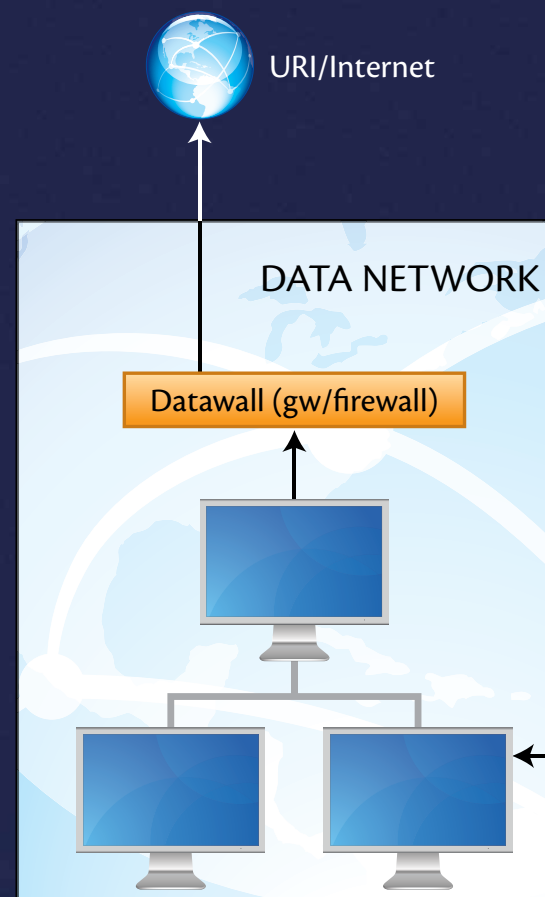

Data Lab

\section{Data Access}

All video and digital data from our publicly funded expeditions are available for scientific use from the Inner Space Center, upon request from the Ocean Exploration Trust. Raw seafloor mapping data are being archived at the National Oceanic and Atmospheric Administration (NOAA) National Geophysical Data Center for inclusion in its database. Future goals include creating a digital data portal for Nautilus expedition data. This centralized database of all expeditions would increase data visibility and provide easier access to the data. In addition, Nautilus is working to increase the near-real-time accessibility to data from shore during expeditions. By expanding telepresence capabilities to include data streams, onshore participants will have more information to help them conduct expeditions remotely. Real-time accessibility of data also allows technical personnel to help troubleshoot from shore. With advances in data accessibility, Nautilus is striving to make ocean exploration accessible to anyone, whether on land or at sea. 


\title{
GEOLOGICAL AND BIOLOGICAL SAMPLE ARCHIVING
}

\author{
By Nicole A. Raineault, Sarah A. Fuller, and Brennan T. Phillips
}

A primary objective of the Nautilus Exploration Program is to make data and samples gathered on exploratory expeditions accessible to the oceanographic community. The Lead Scientist works with Watch Leaders, scientists onshore, and the Data Manager to ensure representative samples of organisms, sediment, and rocks are procured from the deep sea. Using ROV Hercules to collect samples is just the beginning of the process; however, once the vehicle is on deck, the samples are meticulously documented and then archived. Samples and data products are made available to scientists on board during the expedition, and ultimately to dozens of researchers participating from shore or others who request the samples from our partners' archives. The 2013 expedition season yielded 656 samples, including over 200 rock and sediment, 150 genomic tissue, and 250 biological voucher samples that are now available to the US and international scientific communities.
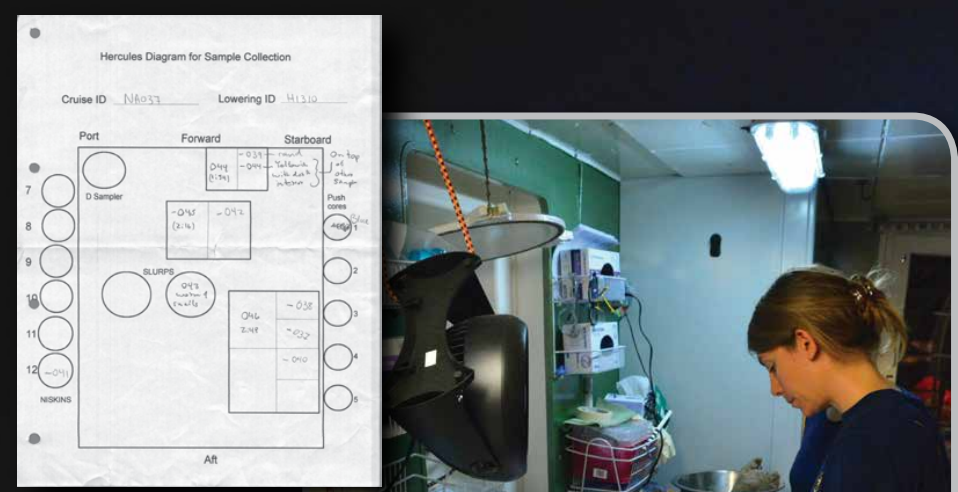

Figure 1 (above).

Basket diagram showing the location of samples on the Hercules ROV.

Figure 2 (right). Data Manager Nicole Raineault writing notes on a sample sheet while processing samples in the Wet Lab.

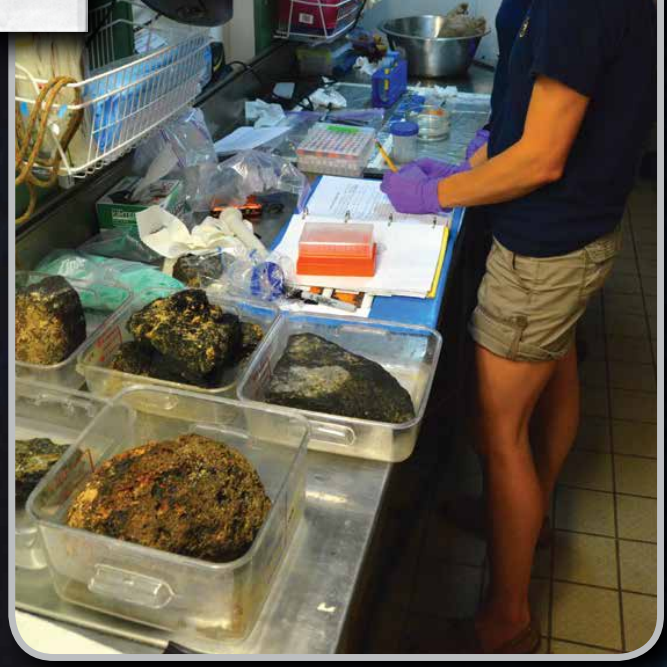

At the end of a typical ROV dive, Data Managers prepare the Wet Lab for sample processing and determine the steps and methods necessary for preservation, based on the types of specimens collected, their physical size, condition, and other attributes. This process is streamlined by readying preservation materials and labeling collection trays with sample ID numbers prior to removing items from the ROV.

Samples that have made the long journey from the seafloor to the deck of E/V Nautilus are carefully transferred from Hercules to the Wet Lab. A "basket diagram" drawn during the dives shows the containers, push cores, Niskin bottles, suction samples, and other devices and the samples they collect, each with an assigned ID number (Figure 1). Sample identification includes the cruise number and sample numbers starting at 001, increasing incrementally throughout the expedition, for example, NA039-001.

When samples are brought into the Wet Lab for documentation, the Data Manager, science interns, and partnering scientists collaborate to photograph each sample with scale bars and identifiers (Figure 2). Rock samples are inspected for encrusting or sessile organisms, which may be removed from the rock and preserved as subsamples. Subsamples are also noted in the logs, along with their method of preservation and archival destination. Biological samples are often photographed with a macro lens or under a microscope to reveal details that can help biologists identify the organism (Figure 3), and then they 


\section{NAUTILUS EDUCATION PROGRAMS}

By Allison Fundis, Samuel Garson, and Katrina Cubina

Through educational programs and at-sea experiences aboard Nautilus and other ships of exploration, the Ocean Exploration Trust aims to increase ocean literacy and inspire the next generation to pursue careers in science, technology, engineering, and mathematics (STEM). During the 2013 field season, 62 educators and students from six countries and 22 US states participated in one of several Nautilus Exploration Programs.

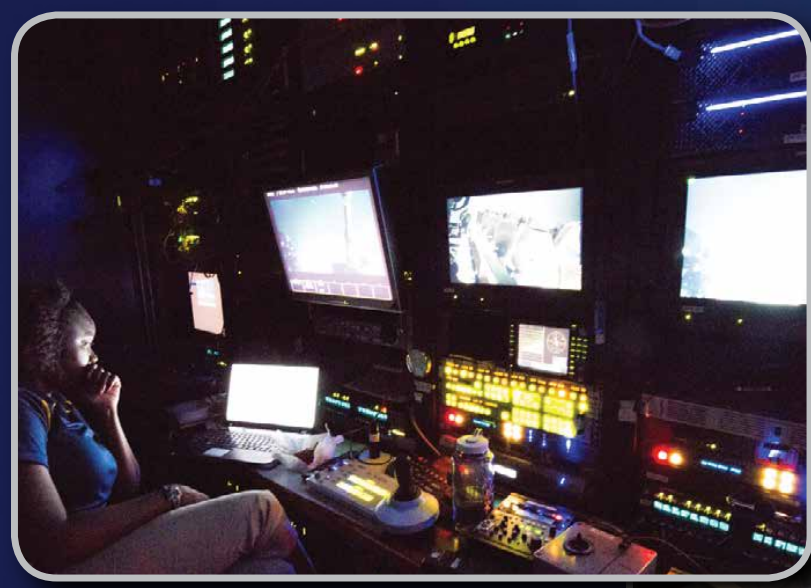

(above) EAS Fellow Aundrea Rue on watch in the Control Room during a Hercules dive.

(right) SEIP Intern Nam Siu inspecting a biological sample recovered by Hercules.

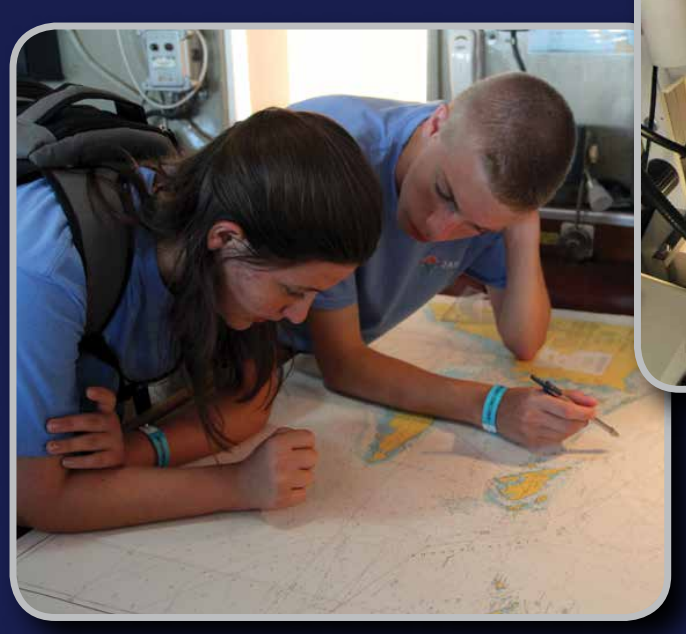

(left) JASON Argonauts learn about navigation on the bridge of Nautilus.

\section{Educator at Sea Fellowship}

In 2013, 21 educators from the United States, Northern Ireland, Venezuela, and New Zealand held fellowships as part of OET's Educator at Sea (EAS) program and served as ambassadors for ocean exploration. The Fellows included informal educators from aquariums, science centers, and nonprofit organizations as well as formal classroom educators from primary school teachers to university professors employed in both the public and private sectors.

The year-long fellowship began with a four-day workshop at the University of Rhode Island Graduate School of Oceanography designed to (1) train participants in effective science communication strategies and hands-on technical skills to equip them with the necessary tools to translate their at-sea experiences to public and student audiences; (2) equip them with a solid foundation for understanding the scientific and engineering goals of the 2013 Nautilus Exploration Program season; (3) integrate them with their respective expedition science and engineering teams; and (4) train participants in the incorporation of the Nautilus Exploration Program in both formal classroom and informal educational settings.

Fellows served as expedition communicators while at sea. Their primary roles were to explain the science and exploration to audiences who were following the expeditions via the Nautilus Live and Bodrum Live websites and through more than 1,600 interactive live connections with groups at schools, aquariums, and science centers. Fellows were also responsible for translating their experiences into STEM-oriented lesson plans or activities for use in their classrooms at home. The Fellows are implementing and improving these lessons and activities through spring 2014; they will be shared with the growing network of Nautilus educators and made available online upon completion. 
Science and Engineering Internship Program

The Science and Engineering Internship Program (SEIP) trains students pursuing undergraduate or graduate degrees in ocean science, engineering, seafloor mapping, or video engineering. During two-to-five week internships aboard Nautilus, students work alongside scientists and engineers as integrated members of the science and operations team. Ocean Science Interns make observations as data loggers, process physical samples in the onboard laboratory, and synthesize scientific findings. Seafloor Mapping Interns process digital bathymetry data and gain experience in interpreting the resulting seafloor maps. ROV Engineering Interns learn about Hercules and Argus maintenance and operating requirements. Video Engineering Interns learn how to operate video for the ROVs and the Nautilus telepresence system that streams live video to shore.

Sixteen interns from the United States, Canada, and Australia participated in the 2013 SEIP, including one student from a NOAA Educational Partnership Program Cooperative Science Center and two from the Marine Advanced Technology Education Center.

\section{Honors Research Program}

OET's Honors Research Program (HRP) provides the opportunity for rising high school seniors to participate in a five-week summer program at the University of Rhode Island Graduate School of Oceanography (URI GSO) followed by an at-sea experience. The onshore component emphasizes the interdisciplinary nature of oceanography and exposes students to the fields of geology, biology, archaeology, and computer science. Students collaborate on research projects aimed to prepare them for their time at sea and to provide them with the opportunity to contribute to the scientific objectives of their expeditions.

In its second year, 12 students participated in the HRP from public and private high schools in California, Connecticut, Hawaii, Massachusetts, Tennessee, Texas, Rhode Island, Virginia, and Washington. The students were trained to use the interactive 4D geospatial processing and analysis software Fledermaus. Learning how to process, visualize, and analyze bathymetric data was the cornerstone of the HRP experience. While at sea, students contributed to expeditions using their abilities to produce high-quality maps in addition to assisting the science team as data loggers during ROV and seafloor mapping operations.

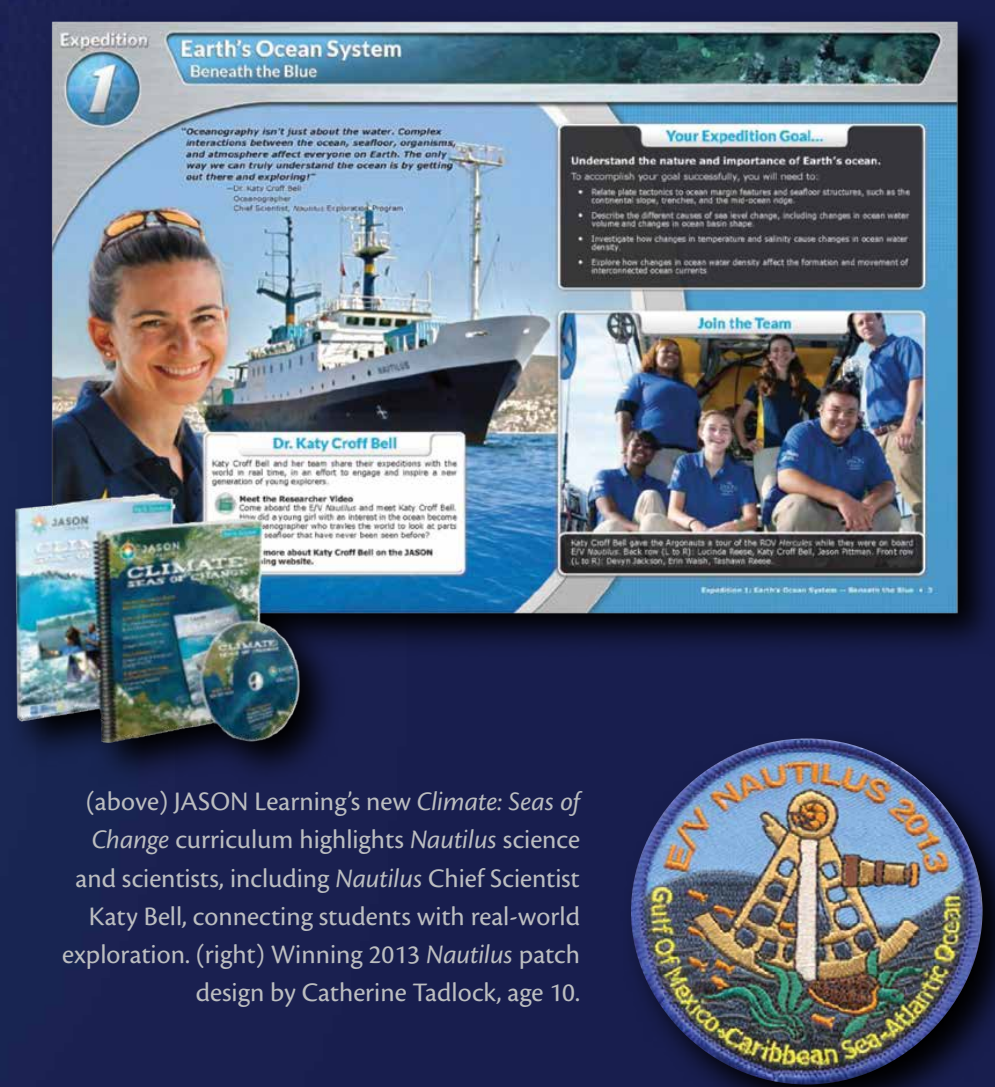

\section{JASON Learning Partnership}

OET continues to collaborate with JASON Learning, our primary partner for K-12 education, through a variety of programs that extend opportunities related to Nautilus to their network of approximately 2 million educators and students. In 2013, JASON Learning launched Climate: Seas of Change, a multimedia curriculum that uses researchers as role models to teach about the nature and the importance of Earth's ocean and climate.

As part of the National Argonaut Program, four educators and nine students joined the team on board Nautilus to experience life at sea and to participate in ocean science and engineering activities. Additionally, multiple members of the Corps of Exploration were featured as STEM Role Models in the online, live JASON series aimed to expose students to diverse career pathways in STEM.

\section{Program Assessment}

Since 2008, OET has cultivated and added new educational programs to promote lifetime learning and inspire the next generation of explorers. To ensure that these programs are most effective in achieving these goals, we continue to work with David Heil \& Associates, an independent firm hired in 2012, to evaluate the 2013 EAS program and its impacts on student learning. In 2013, the HRP was also formally incorporated into the evaluation efforts and the SEIP will be added in 2014. 


\section{EXPERIENCE}

\author{
By Elizabeth Smith, Susan Poulton, and Todd Viola
}

\section{Transforming Everyday Viewers Around the World into Deep Ocean Explorers}

The Nautilus Live digital experience (http://www. nautiluslive.org) allows virtual explorers around the world an opportunity to experience the thrill of discovery alongside the Nautilus Corps of Exploration.

During our 2013 season, we provided immediate online and mobile access to live video and audio feeds from the ship. These live streams included multiple cameras on deck, in our control van in the Wet Lab, and on our remotely operated vehicles, Hercules and Argus, providing a view of multiple shipboard and underwater operations. From June through November, we broadcast 24-hour live coverage over 116 days for a total of 2,800 hours of real-time viewing and 8,400 hours of video content streamed over three separate video channels.

The Nautilus Live website also provided real-time information to enhance the streaming video, including current dive location and ship status, Corps of Exploration audio commentary from the control van during watches, Expedition Leader updates, and Twitter feeds from team members on board and on shore. An active listing of which Corps of Exploration members were currently on watch, including a short biography of each team member, allowed viewers to get to know their guides. During the 2013 season, our network of online explorers of all ages submitted more than 35,000 questions to the shipboard team via Nautilus Live's "Participate" feature, many of which were answered in real time via the live audio feed.

The website also provided information about the science of each of our expeditions, including edited highlights and behind-the-science videos, as well as daily photo albums. Our production team posted a total of 151 videos to the Nautilus Live website via YouTube, which generated more than 50,000 views. A total of 62 photo albums were posted to the website, including deep ocean views from the exploration vehicles as well as topside images showing our Corps of Exploration at work.

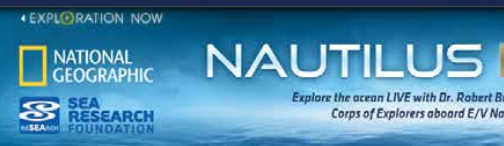

WATCH LVNE THEMISSION THEHICHUCHTS THE TECH THE TEAM THELATEST FOREDUCATORS FORKIDS Q

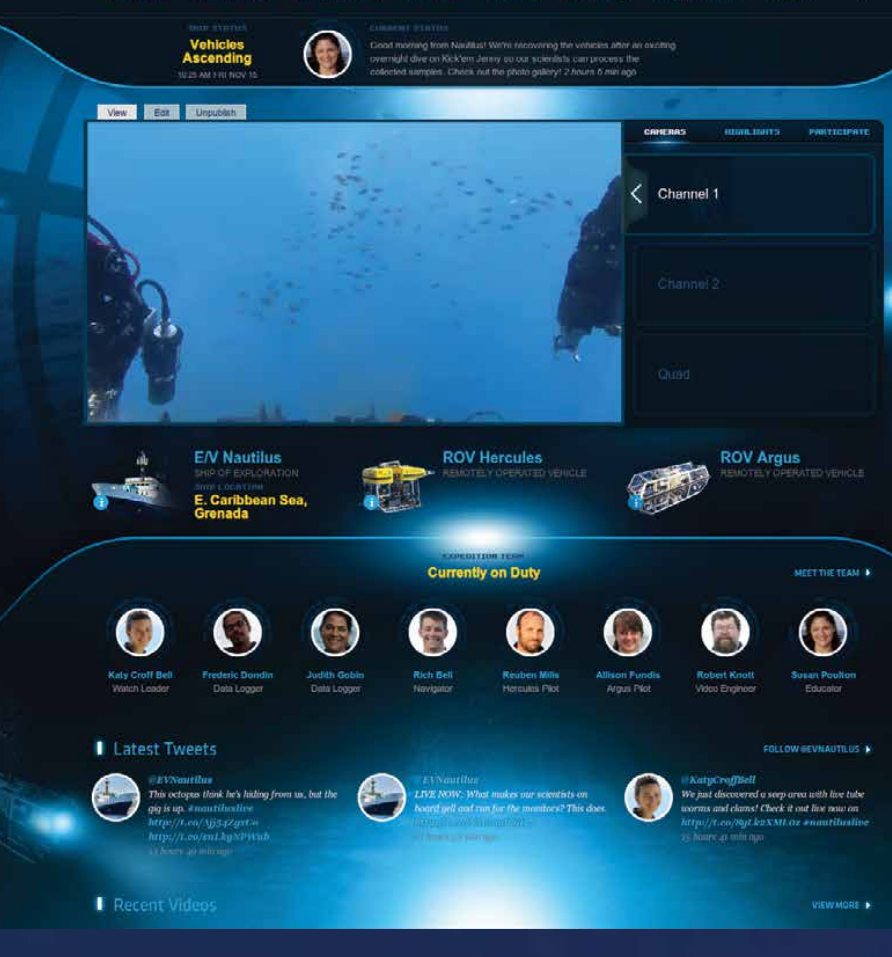

Social media played a powerful role in expanding the audience reach of the Nautilus Live website in 2013 as we continue to inspire future explorers through our Facebook page and Twitter feeds. The Nautilus Live Facebook page saw a $192 \%$ increase in users over the 2013 season, tripling our fan base. Approximately 6,200 Facebook users each day saw our Nautilus Live material via our fan page, for a total expanded reach of over a million. Our E/V Nautilus Twitter feed (@EVNautilus) following increased by 147\%.

Over the course of the 2013 season, the Nautilus Live website saw a record number of explorers join us from their homes, offices, and schools. In all, the site received over 450,000 visits from over 191,000 unique visitors representing 182 different countries. During our expedition in Puerto Rico, Nautilus Live received almost 35,000 visits in a single day, setting a record more than four times greater than that of any day since the site launched in 2010.

Overall, the Nautilus Live website experience continues to fulfill and expand three Nautilus Exploration Program goals: (1) to share our story and our science with explorers around the world via live telepresence from E/V Nautilus; (2) to serve as role models for the next generation of explorers, scientists, engineers, and educators; and (3) to bring our audience only cutting-edge exploration, live from the bottom of the ocean, as we investigate landscapes that have never been viewed before. 


\section{EXPLORATION NOW}

\section{By Scott Munro and Stephen Burke}

Following a successful 2012 season of interactions between E/V Nautilus and Mystic Aquarium, the Ocean Exploration Trust began a new program of live interactions for the 2013 season, called Exploration Now (http://www.explorationnow.org). Through this program, guests at partner museums, aquariums, and science centers are able to interact with members of the Corps of Exploration from E/V Nautilus. Additionally, this year's programming included multiple new venues and research and exploration vessels around the world.

During the height of summer, the Exploration Now team facilitated up to 16 shows per day between our partner sites and ships at sea. Major venue partners included Mystic Aquarium in Connecticut, Exploratorium and Aquarium of the Pacific in California, Houston Museum of Natural Science and Texas State Aquarium in Texas, and the Titanic Belfast Museum in Northern Ireland. We also continued our outreach programs to variety of other schools, universities, Boys and Girls Clubs, and partner sites.

While a majority of the interactions were conducted with Corps of Exploration members on board E/V Nautilus, a significant percentage of this year's interactions were conducted by hosts at the Inner Space Center.
For the first time, audiences were also able to interact with ships actively engaged in scientific research around the world. Foremost among these was R/V Atlantis, operated by Woods Hole Oceanographic Institution. Atlantis ran two telepresence-enabled cruises in the Northeast Pacific Ocean, and conducted nearly 100 live shows through the Exploration Now studios (see pages 20-23). Other partner vessels that participated in live interactions were $\mathrm{R} / \mathrm{V}$ Thompson, operated by the University of Washington, and the NOAA Ship Okeanos Explorer.

Another change this year occurred in the level of produced content included with the interactions. Instead of simply a person talking from the ship's studios, this year's broadcasts included diverse graphical content comprised of text to identify the on-camera talent along with video highlights that visually supported the on-camera responses to venue questions. The Exploration Now editors created these clips in near-real time so that talent on the ships had visual content to accompany their descriptions of exploration, enhancing the experience for shore-based viewers by providing additional content about the technology and science behind each of the expeditions. Reaction to the on-screen graphics and video was universally positive.

While audience numbers vary dramatically between the summer and fall seasons, counts from partner sites indicate that over 35,000 people interacted through the Exploration Now studios in 2013 during a total of nearly 1,700 live broadcasts.

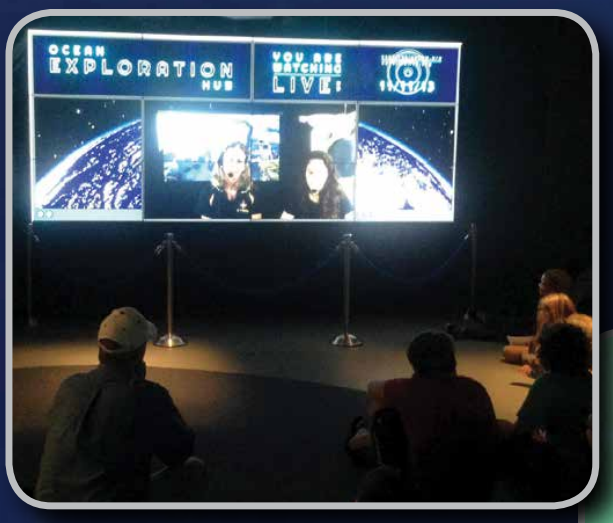

Photo Credit: Aquarium of the Pacific

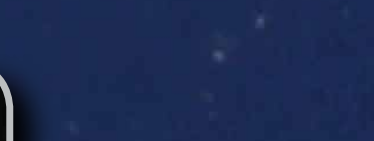


Implementing Telepresence on UNOLS Cruises The Atlantis/Jason telepresence project was conceived in late 2012 and early 2013 after OET and ISC staff presented the telepresence vision to the UNOLS Council. Subsequently, the OET and ISC worked with UNOLS to identify projects that were scheduled to utilize the Jason ROV system in 2013, and found two projects that had $\mathrm{R} / \mathrm{V}$ Atlantis work planned off the Washington and Oregon coasts. To support the telepresence aspects of these cruises, the Office of Naval Research provided funding to purchase satellite time and to support onboard fly-away satellite system technicians and ISC technical and operational services. In addition, the National Science Foundation provided funding to WHOI to develop a mobile telepresence unit (MTU) to be integrated with the Jason topside system to provide video streaming and voice communications capabilities through the satellite link.

In May, following several weeks of preparation, we installed the fly-away satellite system on R/V Atlantis as a temporary solution to provide the high-bandwidth telepresence required for the project (Figure 2). During this time, OET held its annual Science Communication Workshop, which included participants from both Atlantis cruises. This experience enabled selected shipboard participants to learn about the broader educational outreach programs primarily designed and employed by the Nautilus Exploration Program and to see how the shoreside operation works. This workshop allowed for team building, technical orientation, and scientific discussion, all valuable for any telepresence project. At the same time, the Exploration Now production team coordinated the live outreach program, focusing on the Nautilus and Atlantis missions. The ISC facility was modified and improved to meet the demands of supporting multiple ships while the Okeanos Explorer team was also preparing for its field season.

ISC staff designed, built, and configured the MTU for compatible integration into the Jason ROV van and remote viewing station. The system enabled different video feeds and audio sources to be mixed and switched through a simple interface and routed to a high definition video encoder for streaming through the satellite connection. Up to four video feeds and four audio sources can be controlled through the MTU at one time to permit multiple users and multiple cameras to contribute to the broadcast. Along with a lighting kit, a portable high definition camcorder was procured as part of the integrated system. This

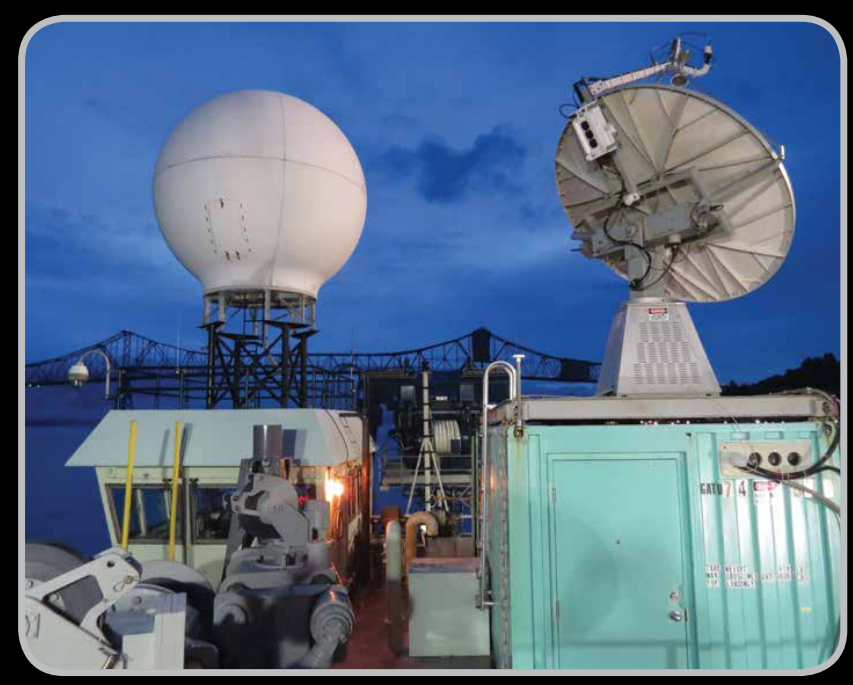

Figure 2. Final setup of the fly-away satellite tracking antenna (right), shown next to Atlantis' HiSeasNet satellite antenna system (left), during mobilization in Astoria, Oregon.

camera could be used to originate recorded video for later playback or as a "host" camera for interactive communications with live audiences on shore. The MTU and Jason control vans were each equipped with IP-enabled voice intercom keypanel systems for real-time ship-to-shore communications with the ISC. A headset and microphone could integrate with the intercom and audio mixer in the MTU to provide multiple audio inputs into the live stream. The MTU could also be used for interactive communications with shore and/or used independently for simple audio commentary during ROV dives. All devices in the MTU were configured to work with the high-bandwidth satellite system as an expansion of the ISC IP network for seamless connectivity to shore.

The two Atlantis/Jason legs were mobilized in Astoria, Oregon, in late June 2013. A team of satellite and video broadcast engineers worked on board to complete the final integration and testing of the telepresence systems. The satellite tracking antenna was fully assembled, configured, and tested, and the MTU was integrated into the Atlantis main lab as part of the remote viewing station, providing the telepresence link between the Jason ROV van and the satellite van through which the feeds were broadcast. One OET/ISC engineer sailed on the first leg to provide technical support for the satellite telecommunications and MTU systems. He trained the shipboard scientific support group (SSSG), an SSSG UNOLS/MATE (Marine Advanced Technology Education) intern, and the Jason technical team members to operate the telepresence gear and to run the systems themselves during subsequent missions. 


\section{Cascadia Initiative Expedition}

The first of the two expeditions aboard R/V Atlantis was in support of the Cascadia Initiative, a four-year experiment to deploy arrays of ocean-bottom seismometers and pressure gauges off the Pacific Northwest coast to better understand earthquake generation in this region, volcanic arc structure, and the formation and deformation of the Juan de Fuca Plate. The goal of this cruise was to recover a large number of the ocean bottom seismometers from various water depths (Figure 3).

Team members established Skype communications between a laptop connected to the large monitor at the remote viewing station via the ship's wireless video camera monitoring network. This configuration enabled the team to host Skype broadcasts from the deck of Atlantis using a mobile tablet to originate and send imagery to the laptop for projection onto the large monitor, and to use that connection to stream shipboard activities to the ISC. The science and education team quickly became familiar with the telepresence setup and the ways to interact with shore. Team members Greg Mulder, Jonas Cervantes, and Dean Livelybrooks organized ways to communicate to shore during the Jason ROV dives to provide real-time commentary and to organize the hosting of live interactions with the Exploration Now partner museums and aquariums. Those team members, along with other members of the science party-students, co-chief scientist Anne Tréhu, Jason team member Jefferson Grau, Lamont-Doherty Earth

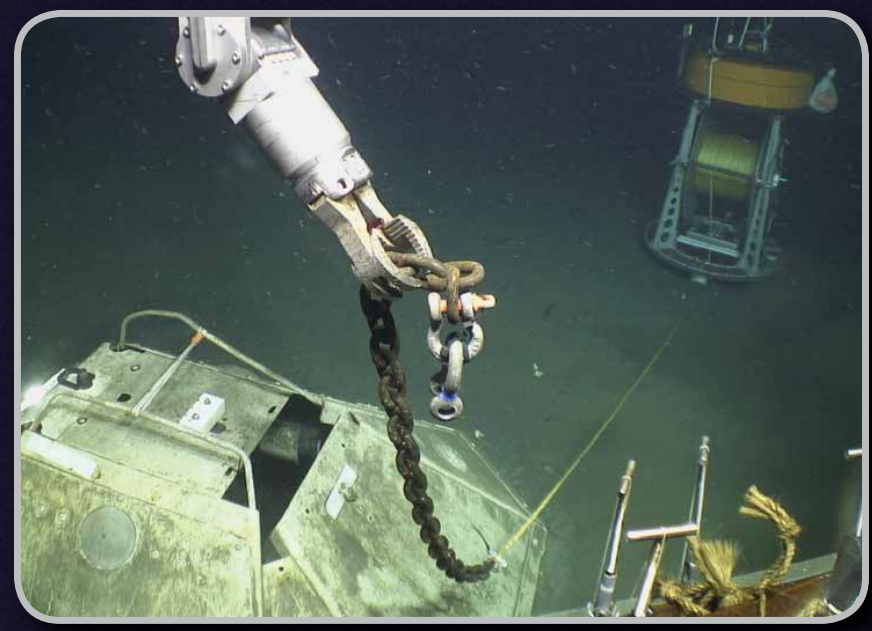

Figure 3. Underwater image of Jason attaching a chain and line from the "elevator" (upper right) to one of the ocean bottom seismometers (inside the trawl-resistant mount,) to facilitate the instrument's recovery.
Observatory engineers David Gassier (a French speaker) and Carlos Becerril (a Spanish speaker)—all took turns hosting these programs and answering questions live from audiences at the partner sites. The underwater camera feeds from Jason and the main lab were live 24/7 to the Atlantis Live website, and the team provided commentary, in several languages, for Internet audiences during events such as Jason dives and instrument recoveries.

Photos and videos were used to explain the particular mission, describe the geology of the Cascadia margin, and communicate the scientific goals of the project. Community college (CC@Sea) participants Haley Domer, Jonas Cervantes, and Greg Mulder also made informative videos from contributed clips, including a presentation about the Linn-Benton ROV club and the MATE ROV competition. Mulder and Cervantes also initiated an outreach activity that involved sending Styrofoam cups to the ocean bottom during one dive. Compression of the cups during the dive facilitated discussion of the effects of pressure in the ocean.

We also employed the broadband connection to test upload to a land-based repository of some of the recovered seismic data files, as a proof of concept. A later Cascadia Initiative deployment cruise aboard R/V Oceanus encountered issues with losing communications with two instruments immediately after they reached the seafloor. Access to WHOI engineers via telepresence likely would have aided attempts to diagnose the equipment problems.

\section{Juan de Fuca Ridge Expedition}

During the second expedition aboard R/V Atlantis, the team conducted operations along the eastern flank of the Juan de Fuca Ridge as part of a National Science Foundation-supported project to study the movement of water in the oceanic crust, the properties of that water, and the microbial communities that call these dark, wet depths home. This work follows Integrated Ocean Drilling Program Expedition 327, which took place in summer 2010; Atlantis/Jason Expedition AT18-07 in summer 2011; and numerous earlier drilling and submersible/ROV expeditions (e.g., Fisher et al., 2011a,b, 2012). As part of this ongoing research, Jason operations in 2013 included returning to six subseafloor borehole observatories to download pressure and temperature data, collect water samples for geochemical and microbial analysis, and retrieve and install 


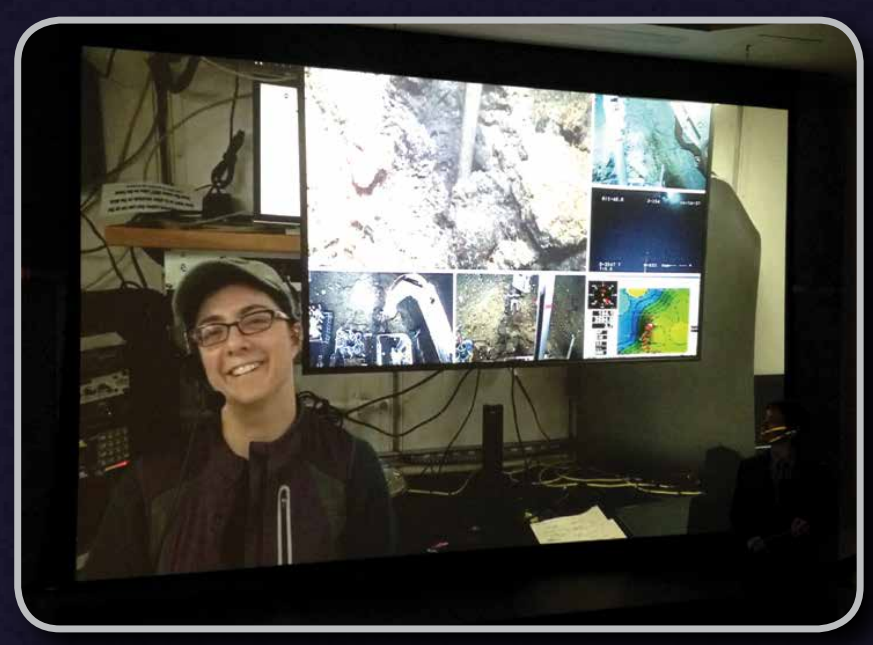

Figure 4. Sharon Katz Cooper conducting a live interactive broadcast with visitors to Q?rius, a new educational facility (digital learning space) at the Smithsonian Institution's National Museum of Natural History during a Jason dive near an instrumented subseafloor observatory.

instruments from at and below the seafloor.

Telepresence-enabled educational programming during this leg included: (1) short-format interactions with informal science education partners, (2) longer-format programs broadcast to expedition members' organizations (e.g., Figure 4), and (3) informal "shows" directed at fairly regular times to Internet audiences. During these shows, the education team interviewed scientists and answered questions submitted through the website. The question of the significance and importance of this research came up many times-it was a major goal of the team to be able to clearly articulate why it makes sense to devote time and resources to basic research. In addition, team members used this web portal daily to update the expedition's activities, post blogs, and add photos and video highlight clips.

In addition to the four people on the education team, numerous scientists answered questions, described their research, and narrated the live stream from underwater cameras. Scientists made regular use of the high bandwidth connection for the educational broadcasts, and also used it to upload data to shore to aid their ongoing scientific work.

Throughout the expedition, there were successes and challenges - equipment was successfully brought back on deck, and data and samples were retrieved, but some instruments were lost or malfunctioned, and one flotation package was found to have had a spectacular implosion. During all of these events, the public was invited to follow along and ask questions.
While it was difficult to gauge the impact on individual museum visitors who took part in the public programming, the numerous questions and comments indicated broad interest and engagement. Even more encouraging was a thank you letter, excerpted below, that the team received after an hour-long program directed to the Seymour Center in Santa Cruz:

So many, many kudos to you, your team, and the NSF. This was a model for what all of us should be doing to educate the public on the value of basic research. At the conclusion of your presentation, one of my anti-government acquaintances came up to me to say that this was indeed research worthy of public support!

\section{Concluding Remarks}

The R/V Atlantis cruise teams were invigorated and encouraged by the addition of telepresence as a part of their work. While at times it was technically challenging, they acknowledged that it has tremendous potential to change the way scientists interact with the public. It also helped the teams better understand how the public perceives their work. Importantly, telepresence expands the number of lay people who know about this kind of basic research and teaches them about the scientific process. We hope to continue this collaboration with scientists sailing on UNOLS ships in the future. 


\section{FIELD SEASON SUMMARY}

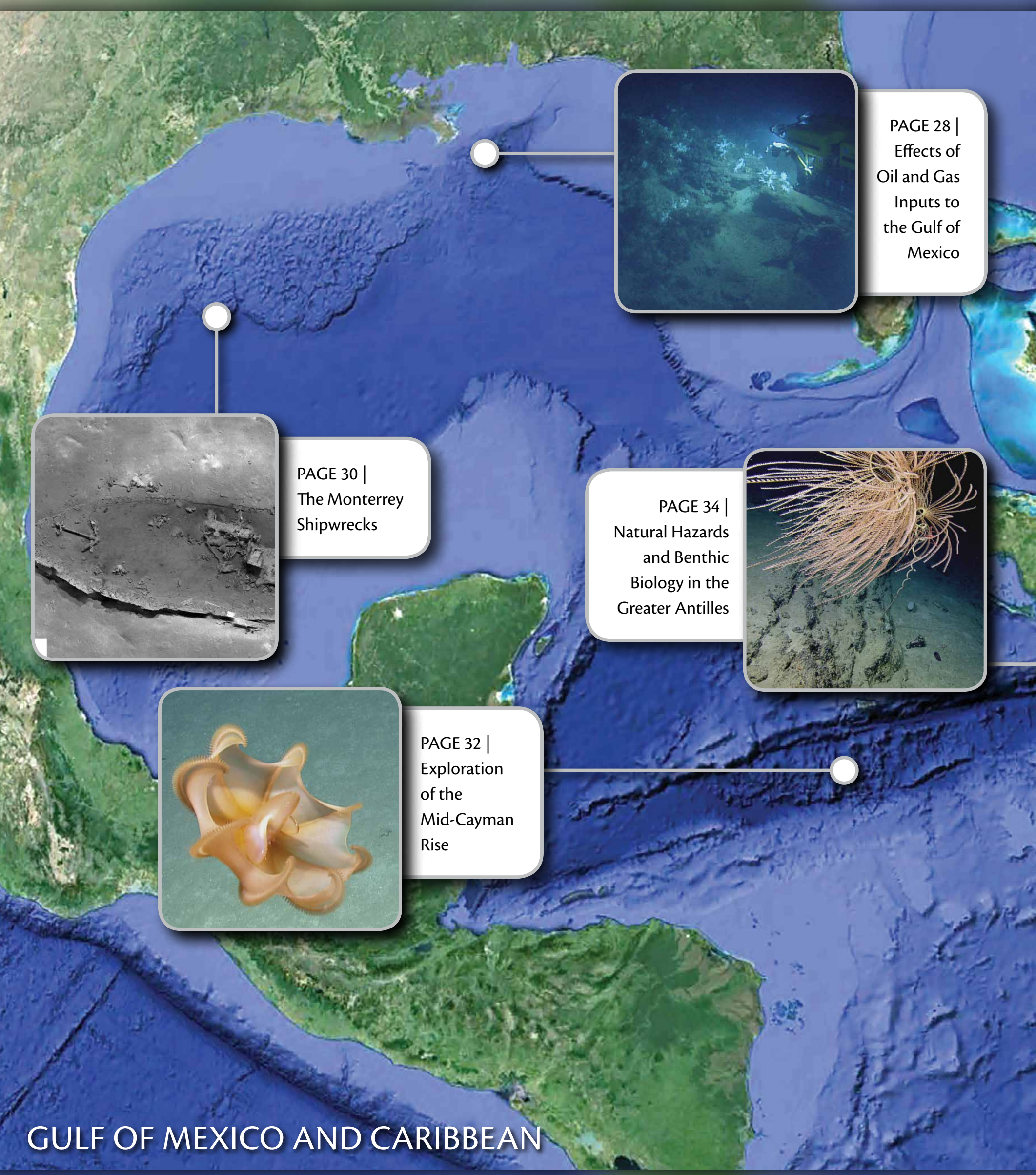




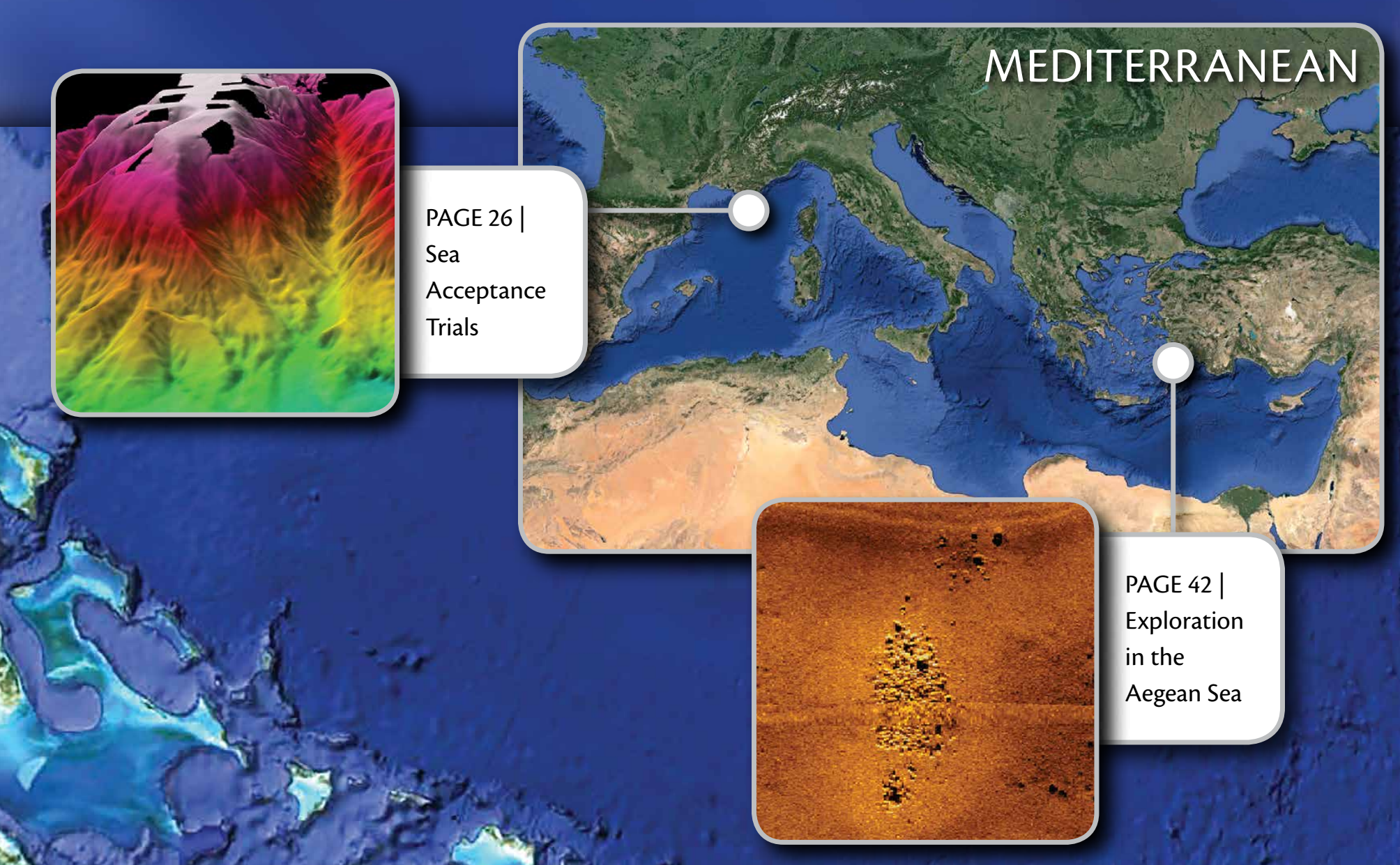

$x_{3}+y^{2}=1$
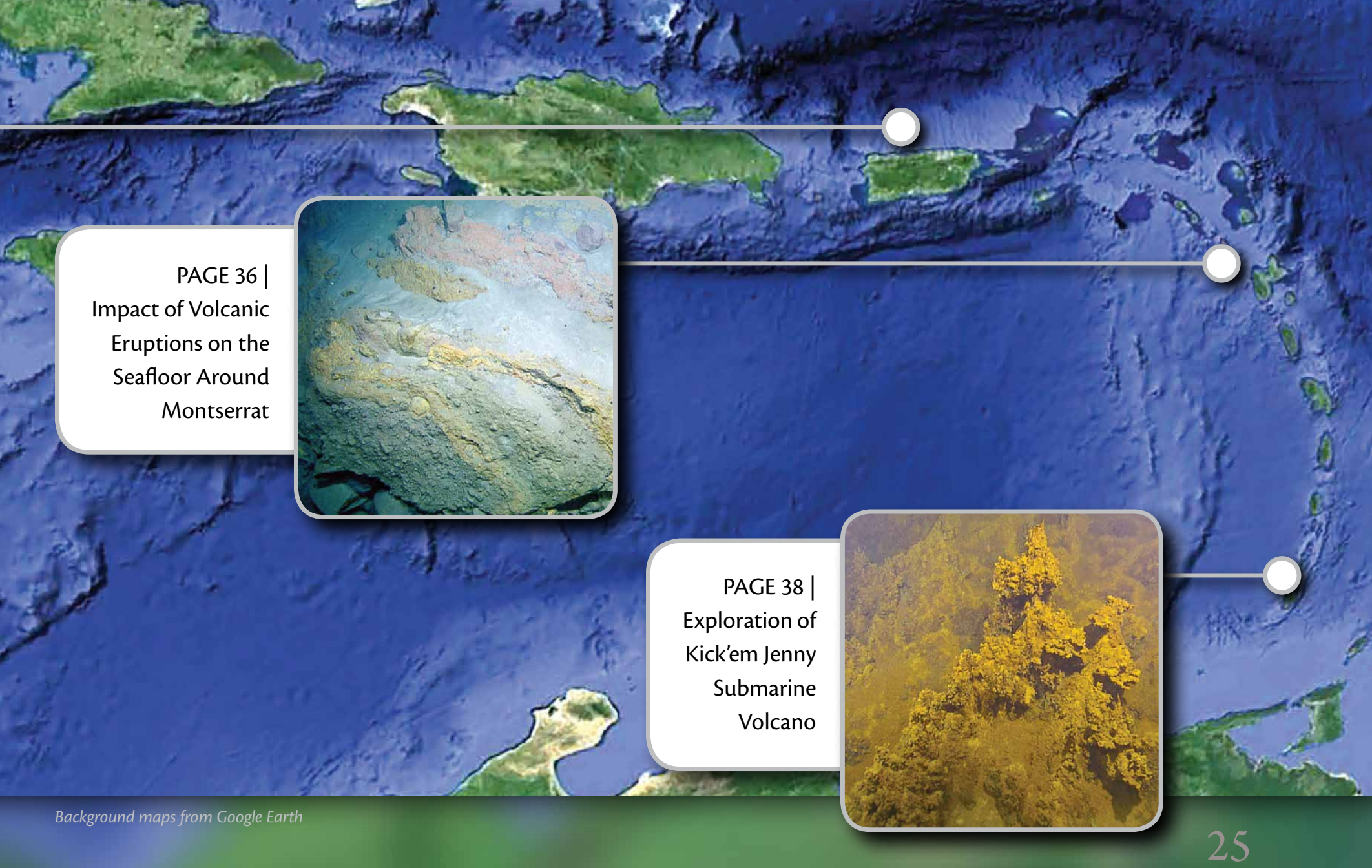


\title{
Sea Acceptance Trials of the Multibeam Echosounder and Subbottom Profiler
}

\author{
By Nicole A. Raineault, Jonathan Beaudoin, Paul Johnson, Xavier Lurton, Christophe Vrignaud, \\ Anne Pacault, Timothy Gates, Marisa Yearta, Jean-Marie Augustin, Henri Floc'h, \\ Sarah Duduyer, and Yves Le Gall
}

A new seafloor mapping system was installed on E/V Nautilus in early 2013, revolutionizing the way the ship explores the ocean. Not only can the Kongsberg EM 302 multibeam echosounder (Figure 1) create maps of the seafloor, it can also provide information on bottom type from backscatter data, similar to the side-scan sonar Diana. Additionally, the multibeam can be used to locate plumes in the water column created by hydrothermal vents or gas or oil seeps. Together with the new Knudsen 3260 subbottom profiler, these acoustic instruments will provide improved maps of the seafloor to help scientists choose dive locations and to improve situational awareness for navigators and ROV pilots. Data are archived at NOAA's National Geophysical Data Center, allowing anyone to obtain raw or gridded seafloor bathymetric data collected during Nautilus's exploratory cruises.

Sea acceptance trials, conducted in the Mediterranean Sea off of Toulon, France, in April 2013 allowed experts in acoustics to run a series of eight systematic tests to fine-tune the system, ensuring accuracy and precision of acoustic data products (Figure 2). A multinational team of the world's leading specialists in sonar engineering and data processing, including scientists from the University of New Hampshire, a French oceanographic institute
(IFREMER), and the French Hydrographic Office (SHOM) led the planning, cruise operations, and postcruise analysis with the Nautilus team.

Initial acoustic tests examined the noise generated by Nautilus at different speeds and headings. Several onboard acoustic sensors measured variations in ship-generated noise. A comparison of these noise measurements and examination of mapping data quality showed that Nautilus is an extremely acoustically quiet ship. Typical ship-generated noise, including bubbles generated by the hull, are not an issue on Nautilus even at a cruising speed of 10 knots. Consequently, under most conditions, Nautilus can map the seafloor without reducing speed.

Second, system "patch tests" were conducted to correct offsets between the differential GPS antennae pair, the motion reference unit (MRU), and the multibeam transducers. The GPS antennae provide precise positioning for the mapping data, and the MRU measures roll, pitch, heading, and heave associated with ship motion. Any offsets in time between these systems are also measured. Positioning and attitude data must be applied to the multibeam data to correct for the ship's motion and accurately map the seafloor. A surveyor measured geometric offsets between the GPS, the MRU, and the transducers upon installation, but only repeated mapping of a small "patch" of seafloor allows fine-tuning of these offsets to ensure accuracy. The offsets were verified by completing a secondary patch test.

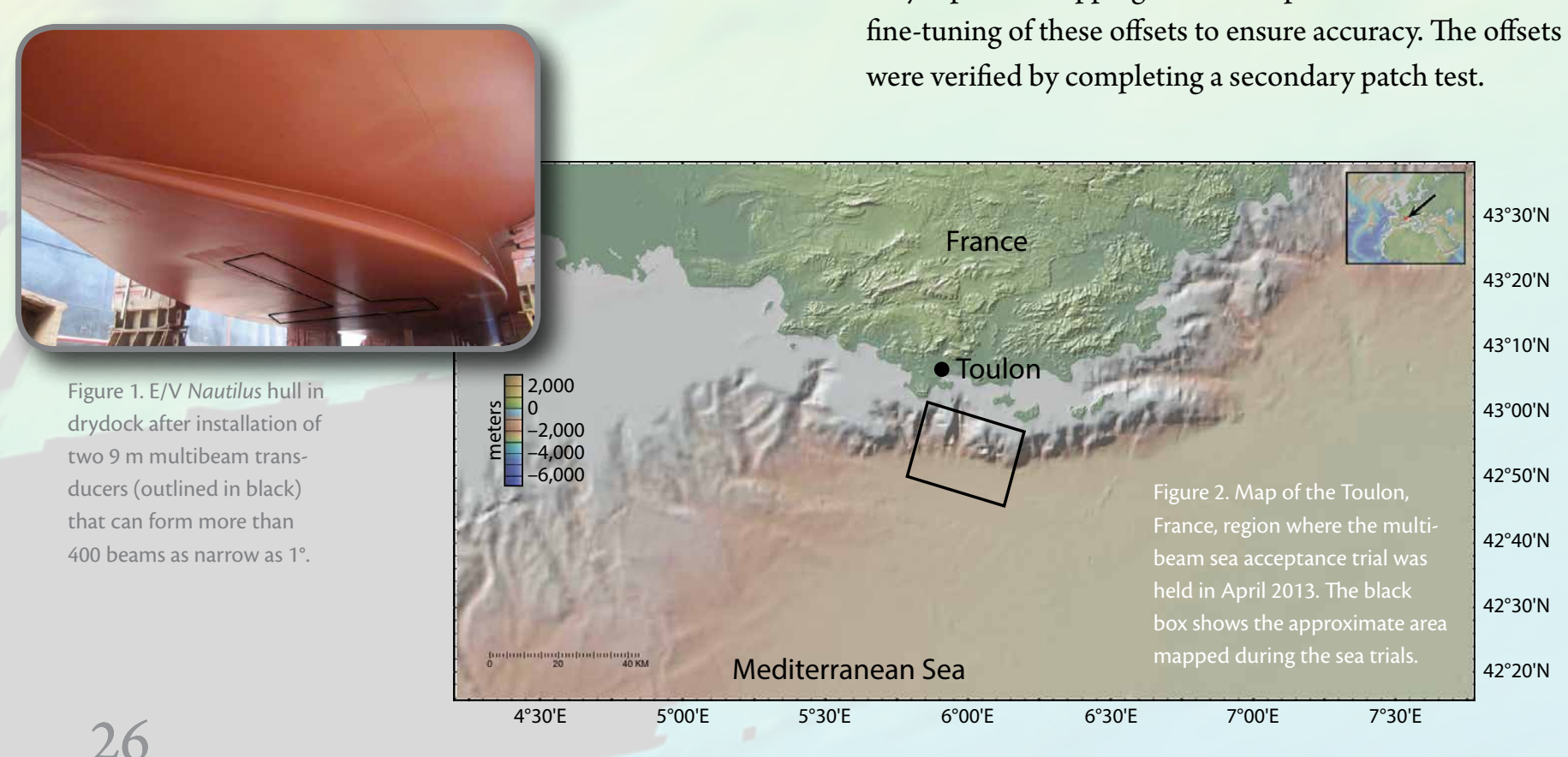




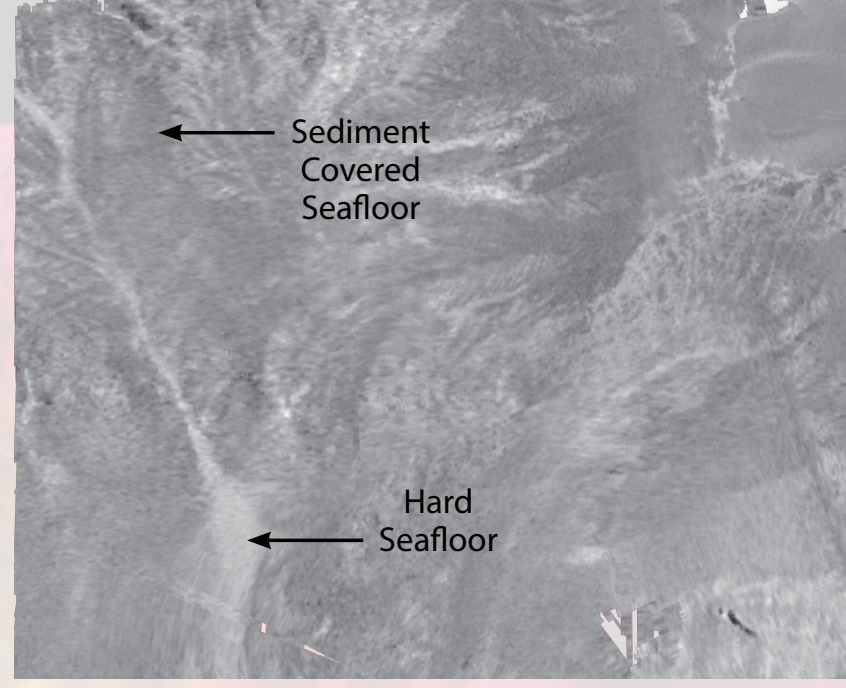

Third, a deepwater $(2,400 \mathrm{~m})$ flat reference area was mapped. This well-mapped patch of seafloor is used by SHOM and IFREMER to test the vertical accuracy of their multibeam systems. Nautilus EM302 data were compared to the reference survey of the area, and the Nautilus system easily met deepwater mapping standards ( $\pm 2 \%$ vertical uncertainty) without any significant post-processing.

The fourth test calibrated the multibeam backscatter, which is a measure of the intensity of sound returned from the seafloor. Scientists use backscatter to determine seafloor type and characteristics, such as grain size and seafloor roughness (Figure 3). Backscatter maps help locate particular habitats by showing, for example, hard-bottom areas, which usually host more abundant and diverse macrofaunal communities. In shallow water, backscatter from the EM302 can also reveal sand waves or dunes and objects on the seafloor, including shipwrecks.

The canyons off of Toulon provided an excellent environment in which to test the bathymetric coverage of the multibeam system over dramatically changing bottom topography (Figure 4). A single ping from the multibeam is expected to cover up to 5.5 times the water depth across the beam of the ship (e.g. 5,500 m coverage in 1,000 m water depth, up to a maximum of $8 \mathrm{~km}$ coverage). Results show 2.5-7 times water depth coverage in depths ranging from $110-2,450 \mathrm{~m}$, meeting or exceeding expected coverage and allowing Nautilus to efficiently map large areas of the seafloor.

Vertical and horizontal accuracy tests conducted in shallow water $(110 \mathrm{~m})$ at another SHOM reference area showed the soundings to be accurate within $\pm 1.3 \% \mathrm{~m}$ vertically from the reference map. For the horizontal tests, we mapped a known shipwreck and compared it to known geo-positions (Figure 5). The system performed better than called for by the most stringent standards.
Figure 3. Backscatter mosaic showing the branching canyon system with hard-bottomed canyon floors (light-colored areas) and sediment-draped canyon walls (dark-colored areas).

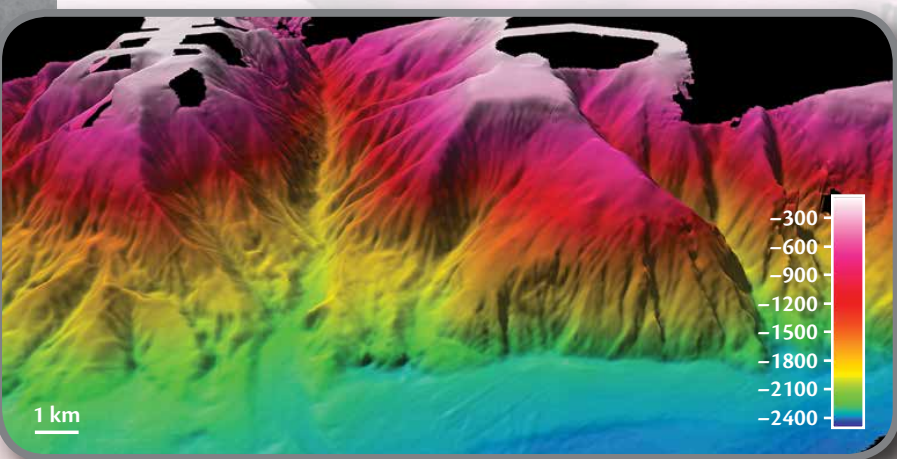

Figure 4. Digital elevation model of the canyons south of Toulon from multibeam data collected by E/V Nautilus. (Depth scale is in meters and $3 x$ vertical exaggeration).

Along with the EM302 operations, a dedicated team worked on the trials of the subbottom profiler. Much simpler than a multibeam system, this echosounder transmits low-frequency "pings" inside a vertical beam. The signals can penetrate the sediment, and return echoes make it possible to draw a cross section of sediment structure below the seafloor. These data are a very useful complement to the bathymetry and seabed-interface information provided by the multibeam echosounder. The results obtained with the Knudsen subbottom profiler were satisfactory.

Finally, endurance tests of both the multibeam and subbottom systems showed that both could run for more than 10 hours without any problems. However, the true endurance test of the multibeam system occurred over the next three weeks as Nautilus mapped its way across the Atlantic, from Toulon, France, to Galveston, Texas, where we started the 2013 expedition season.

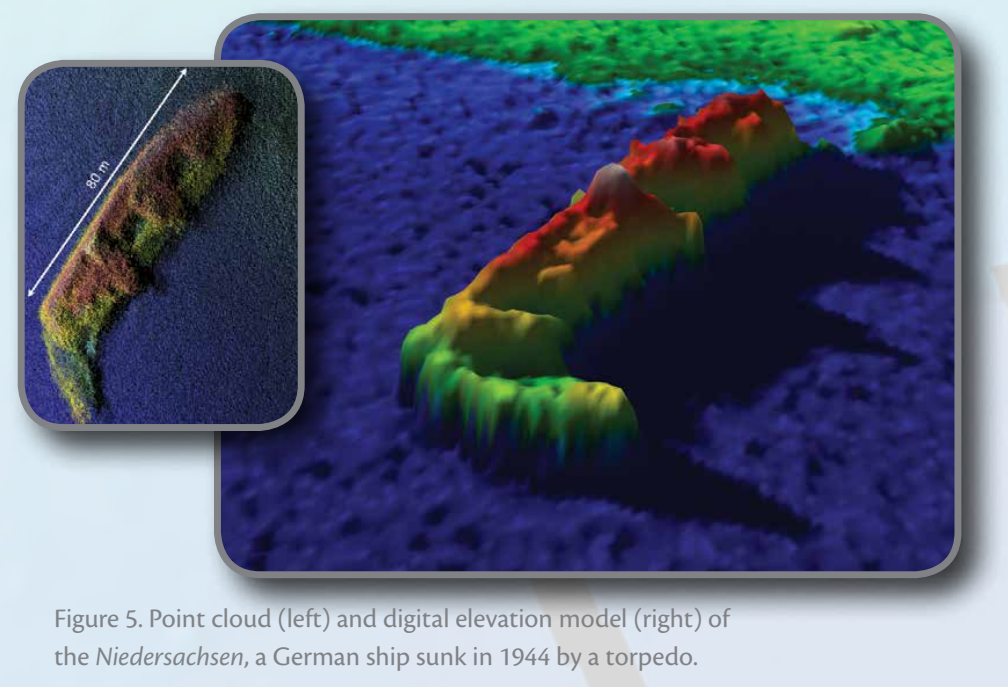




\title{
Exploring Deep-Sea Coral Communities and the Effects of Oil and Gas Inputs to the Gulf of Mexico
}

\author{
By Erik E. Cordes, Samantha P. Berlet, Zena Cardman, Richard Dannenberg, Amanda W.J. Demopoulos, \\ Samuel E. Georgian, D. Caleb King, Danielle L. McKean, Danielle M. Young, and Dannise Ruiz Ramos
}

The deep Gulf of Mexico is home to some of the most active natural oil and gas seeps in the world. It is estimated that over 1,000 natural seeps release more than 140,000 tonnes of oil per year into the Gulf of Mexico (MacDonald et al., 1993; NRC, 2003). These seeps support different types of communities, from microbes with diverse metabolic capabilities, to chemosynthetic organisms and numerous species of associated fauna.

Seep communities pass through a series of successional stages as the composition of the chemicals in the seeping fluid and the rate of seepage change (as reviewed by Cordes et al., 2009). Early on, when fluid flux is rapid, the communities consist of microbes and occasionally chemosynthetic clams half buried in sediment. Over time, the microbial oxidation of methane and higher hydrocarbons results in authigenic carbonate precipitation. At this point, seepage slows, and bathymodiolin mussels with methane- and sometimes also sulfide-oxidizing symbionts colonize the sites. As fluid flow continues to abate, vestimentiferan tubeworms colonize and eventually dominate the seep. These animals fuel their sulfide-oxidizing symbionts by using long, root-like projections to mine sulfides found deep within sediments. After seepage has slowed and is no longer apparent at the sediment surface, corals begin to colonize the authigenic carbonates. This last transition, which may take thousands to tens of thousands of years, is the least well understood.

The 16-day cruise supported the ECOGIG consortium (Ecosystem Impacts of Oil and Gas Inputs to the Gulf, funded by the Gulf of Mexico Research Initiative) to visit benthic communities, primarily deepwater corals, in the vicinity of the Macondo well, the location of the 2010 oil spill following the explosion of the Deepwater Horizon drill rig (Figure 1). The goals of the cruise were to understand the effects of both natural seepage and the enduring impacts of the oil spill on deepwater coral communities.

The first task was to collect our target species of corals, Callogorgia americana, Paramuricea biscaya, Leiopathes glaberrima, and Lophelia pertusa (Figures 2 and 3 ).

Onboard experiments exposed C. americana, P. biscaya, and L. glaberrima to a series of concentrations of oil and dispersant to determine their response in terms of survivorship and gene regulation. While collecting these corals, we discovered C. americana very near some natural seeps. This species is often associated with areas of increased seep activity

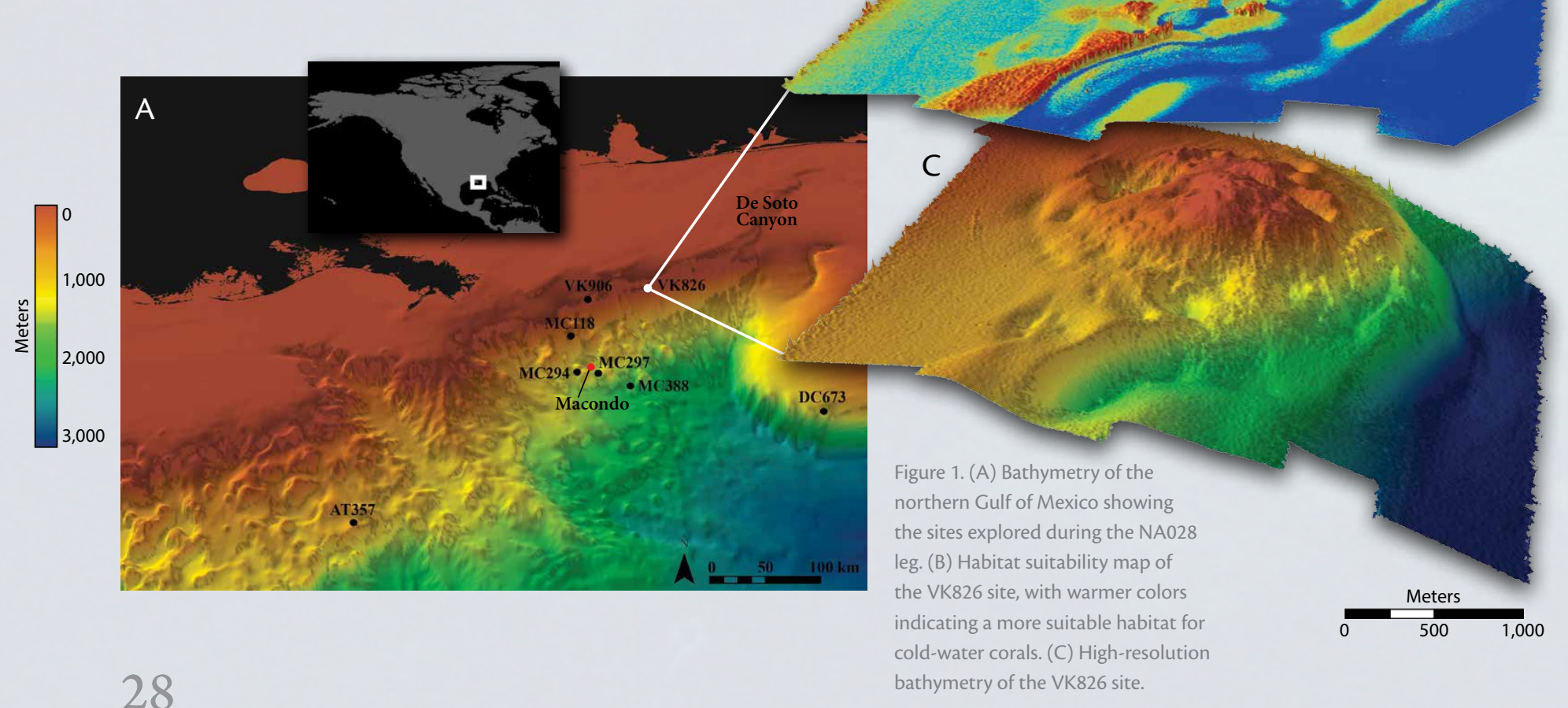


(Quattrini et al., 2013), although the nature of the link to the seeps remains elusive. We also collected L. pertusa and some sponge species in order to examine their metabolism and respiration under different conditions. For L. pertusa, we conducted a short-term feeding experiment to determine the degree to which food is shared among polyps, and we transported living L. pertusa colonies to our home laboratories for more extensive experimentation. Sponges were examined for the presence of nitrification, a biogeochemical process that is responsible for transforming nitrogen in the environment (Southwell et al., 2008).

During the cruise, the impacts of the Deepwater Horizon oil spill guided our work and set our priorities. Previous studies demonstrated the direct impact of the spill on a deep-sea coral community found approximately $11 \mathrm{~km}$ to the southwest of the former location of the drilling rig (White et al., 2012). Each coral at this site had been assigned a name, and physical markers had been placed around the site to ensure that it could be relocated (Hsing et al., 2013). Work during our expedition was the seventh time since 2010 that these corals had been imaged. This monitoring has revealed that the corals are not recovering and continue to be heavily impacted, though some corals that sustained relatively light damage appear to be improving (Hsing et al., 2013). By following the changes in appearance of these coral colonies over time, we can elucidate the impact of the oil spill at other sites that were discovered later.

We examined deep-sea coral communities in their natural states at number of other sites, both near to and far from natural seepage. We collected different species of corals in close proximity to one another to see how their microbial communities varied. In addition, we collected push cores adjacent to corals and along transects moving away from microbial mats to assess sediment macrofaunal and microbial communities and their geochemical environment. Sediment macrofauna, highly sensitive to disturbance (Montagna et al., 2013), have been examined since the spill to monitor temporal changes in these communities.

At many sites, the ROVs Hercules and Argus traveled over areas of the seafloor that had never before been imaged. The vehicles encountered extensive mounds of L. pertusa at Viosca Knoll, where they had not been previously known to exist. At another site in the Atwater Valley area, new, high-resolution multibeam bathymetry recently acquired with autonomous underwater vehicles from the University of Mississippi led to the discovery of a
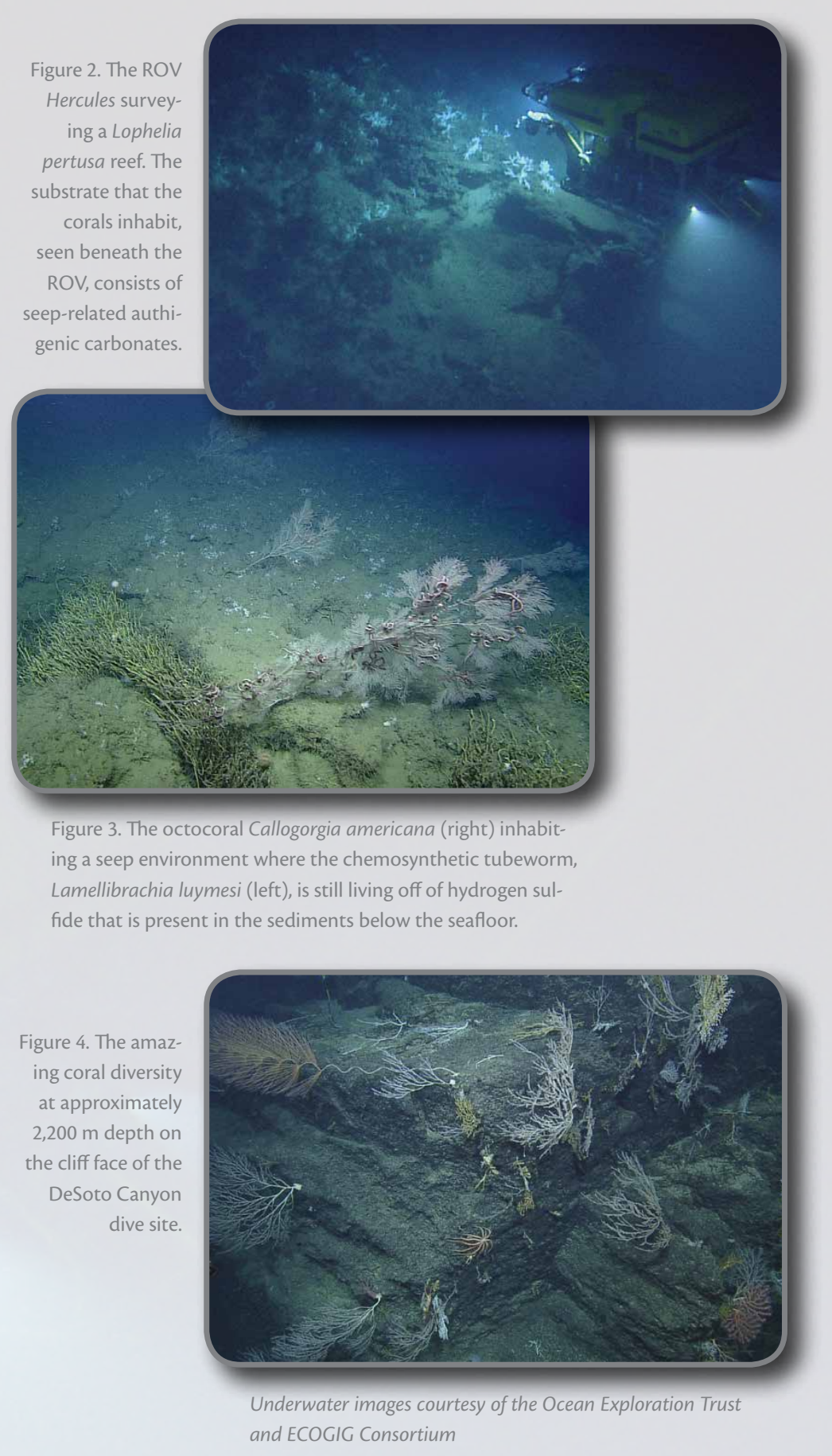

new deep-sea coral community in a previously unexplored region. The most spectacular discovery of the cruise was the coral community thriving on a $200 \mathrm{~m}$ high vertical cliff face in an area of DeSoto Canyon at over 2,000 m depth (Figure 4). The diversity of this site was amazing, with at least 13 species of deep-sea corals and at least five species of sponges observed.

Overall, we made 14 dives with ROVs Hercules and Argus and acquired 182 samples-a new record for an E/V Nautilus cruise. The primary goals of the mission were all achieved, and new deep-sea coral communities were discovered, decreasing by just a small increment the amount of the seafloor that remains to be explored. 


\title{
The Monterrey Wrecks: Characterization of Three Early $19^{\text {th }}$ Century Shipwrecks in the Gulf of Mexico
}

\author{
By Jack Irion, Frank Cantelas, James Delgado, Amy Borgens, Frederick Hanselmann, Christopher Horrell, \\ William Kiene, Steve Gittings, Michael L. Brennan, Alicia Caporaso, Catherine Marzin, and Jamie Wagner
}

In April 2012, the NOAA Ship Okeanos Explorer conducted the first reconnaissance of a shipwreck site $275 \mathrm{~km}$ from the Texas-Louisiana coast as part of an interdisciplinary exploration mission focusing on deepwater hard-bottom habitat, naturally occurring gas seeps, and potential shipwrecks in the Gulf of Mexico. First identified as a side-scan sonar target in 2011 by Shell Oil during a lease-area survey, a brief ROV dive imaged the undisturbed, early nineteenth century wooden-hulled, copper-sheathed sailing vessel containing artillery, firearms, navigation instruments, cooking and food storage items, medicines, and personal effects. "Monterrey A" is one of the more significant shipwrecks discovered in the Gulf of Mexico to date because of its degree of preservation and the insight it provides into a critical period in history when new nations were forming at the end of Colonial period and the Gulf of Mexico was opening to global trade.
In a partnership between the Meadows Center for Water and the Environment at Texas State University and the Ocean Exploration Trust, a team of archaeologists and other scientists returned to the site in July 2013 aboard E/V Nautilus first to document the wreck in detail (Figure 1) and then to recover a small number of artifacts for analysis (Figure 2). These items will help determine the historical and socio-cultural context within which the ship operated and, hopefully, identify it. All work was done under a Federal Antiquities Act permit and conformed to the standards in the Annex of the UNESCO Convention on the Protection of the Underwater Cultural Heritage. After the artifacts are properly conserved, they will be placed in a public museum for curation and display.

After completing work on the Monterrey A wreck, Nautilus navigated to two other potential wreck sites also identified by the Shell survey. Now known as Monterrey

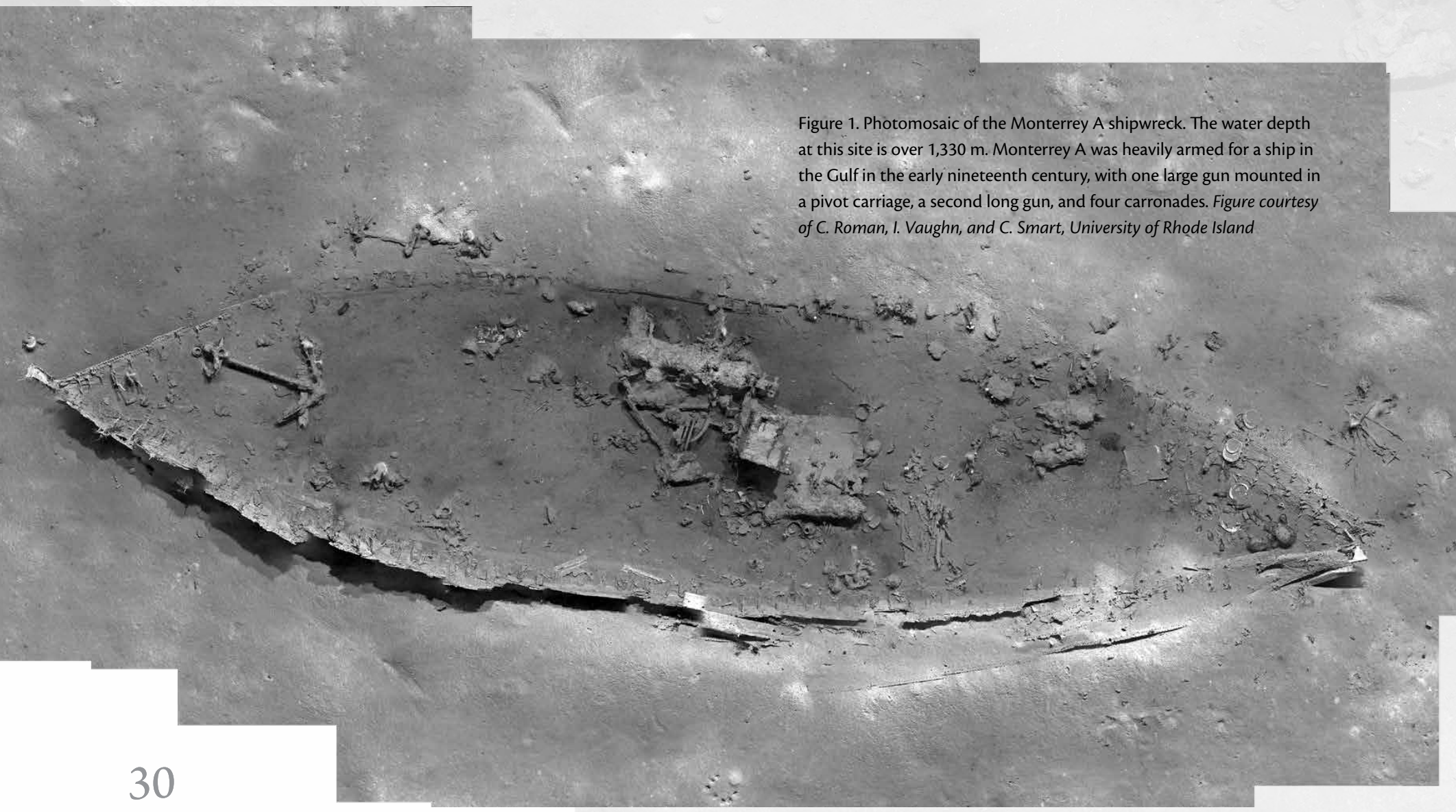




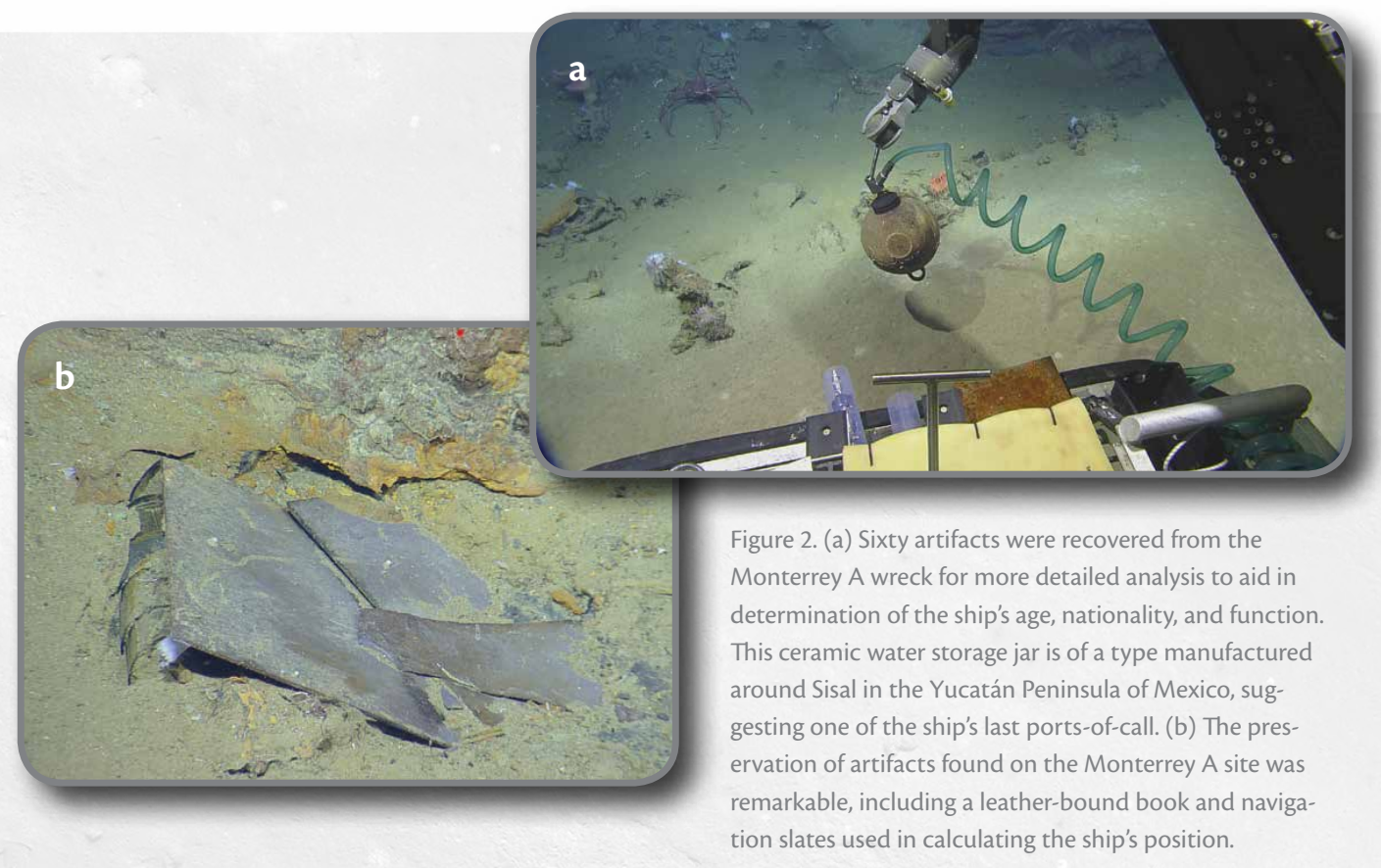

While aboard Nautilus,
we shared our discoveries
and findings with the
public through a vari-
ety of media, including
telepresence and video
streams. In a return mis-
sion to more completely
study wrecks B and C and

$\mathrm{A}, \mathrm{B}$, and $\mathrm{C}$, these three vessels appear to be a privateer or a pirate vessel (A) and two ships (B and $C$ ) that were possibly prizes captured by the first. Wrecks B (Figure 3 ) and C (Figure 4) were documented by video, still photography, and high-resolution imaging only; no samples or artifacts were recovered. Photos of all three vessels suggest they share some common artifacts, hence, they may have sunk at the same time, most likely in a violent storm. Preliminary studies suggest that if Monterrey A was a privateer and $\mathrm{B}$ and $\mathrm{C}$ were its prizes, this may be the first time ever that archaeologists have discovered a privateer/pirate ship with its captures.

Early studies suggest that Monterrey A may be an American-built ship associated with the activities of the "Baltimore patriots." They were active after the War of 1812 as American ships and crews waged an economic war against Spanish shipping in the Caribbean and Gulf of Mexico in support of South and Central American independence from Spain. Monterrey B is a small, uncoppered wooden vessel that sank with a cargo of bound rolls of cattle hides, horn, and blocks of tallow (beef fat), which were found preserved on the wreck. Monterrey $\mathrm{C}$, seemingly without a cargo, was a larger, copper-clad vessel with a huge anchor and stone ballast. If it did have a cargo, it may have been something perishable. The three ships may have been heading for Galveston, a port held by independent Mexican rebels aligned with the French privateers Louis Aury and Jean Laffite, to deliver the hides, horn, tallow, and possibly slaves or tobacco, all common prizes taken and sold at Galveston during this period.

to recover artifacts from them, we expect to reach an even larger audience so that the world can watch and participate as science and discovery unfold in real time.

Underwater images courtesy of the Ocean Exploration Trust and Meadows Center for Water and the Environment

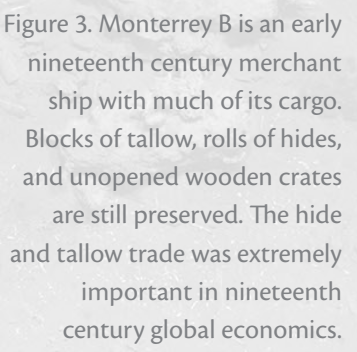

Figure 3. Monterrey $B$ is an early nineteenth century merchant ship with much of its cargo. Blocks of tallow, rolls of hides, and unopened wooden crates are still preserved. The hide and tallow trade was extremely important in nineteenth century global economics.
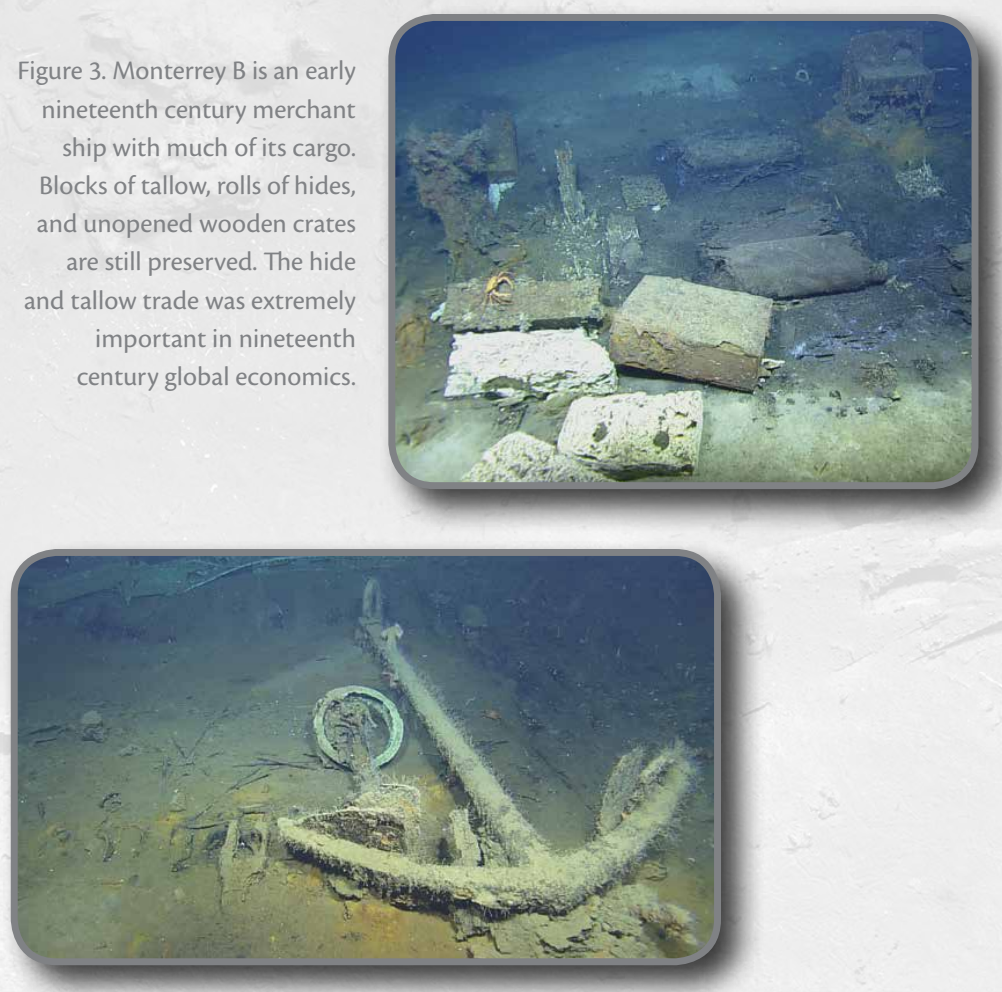

Figure 4. Monterrey $\mathrm{C}$ is the largest of the three ships, but also the least well preserved. It was heavily damaged when the ship struck the bottom with great force, shifting a large amount of stone ballast and most of the artifacts to the stern of the ship. One unique feature of the site is a very large anchor amidships lying next to a brass-bound capstan. 


\title{
Exploration of the Mid-Cayman Rise
}

\author{
By Cindy Van Dover, Katherine L.C. Bell, Leigh Marsh, Chris German, Barbara John, Michael Cheadle, \\ Mike Vecchione, Diva Amon, Bernard Ball, Jon Copley, Clara Smart, Sarah A. Fuller, Brennan T. Phillips, \\ Kathleen Cantner, Steven Auscavitch, and Robert D. Ballard
}

Mid-Cayman Rise objectives were built on exciting results from a flurry of recent expeditions that investigated hydrothermal sites in the region (German et al., 2010, 2012). The 2013 E/V Nautilus cruise explored oceanic core complexes (OCCs), tall, smooth-sided hills that rise from the seafloor on the flanks of some mid-ocean ridges. Dives (Figure 1) explored the full extent and nature of life around the Von Damm hydrothermal field, previously discovered there, as well as the geology to further understanding of the vents' origins, and to survey the OCC summits that had never before been investigated by a deep diving vehicle. This 2013 study was the first Nautilus cruise to have more scientists participating in the expedition from locations on shore than from the ship, tripling the size of the science party.

\section{Ecology of Von Damm Hydrothermal Vents}

The Von Damm site was one of the most visited vent sites in 2013, with dives by ROV Isis from RRS James Cook in February, HROV Nereus from R/V Falkor in June, HOV Shinkai 6500 from R/V Yokosuka, and ROV Hercules from E/V Nautilus in August. Our Von Damm vent biological studies focused on collecting and assessing the diets of the vent shrimp, Rimicaris hybisae, from closely spaced,

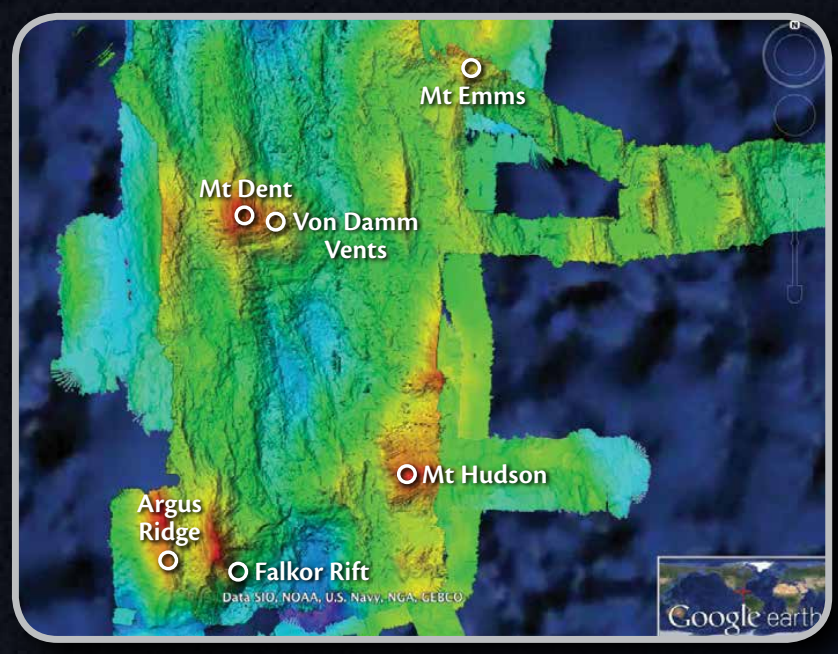

Figure 1. Multibeam map of the Mid-Cayman Rise. Multibeam data are from NOAA Ship Okeanos Explorer, R/V Falkor, and E/V Nautilus. dense, and sparse aggregations (Figure 2). These shrimp host epibiotic microorganisms on the fold of the branchiostegites that cover the gill chamber. By analogy to Rimicaris exoculata, which behaves in the same manner as $R$. hybisae, forming swarming aggregations on mineral precipitates associated with venting fluids, we expected the gut contents of $R$. hybisae to be full of minerals and microbial remains. Fourteen individuals of $R$. hybisae from dense aggregations did have gut contents loaded with microorganism remains, but eight of 12 shrimp from sparse aggregations $\sim 1 \mathrm{~m}$ distant contained either only remains of crustacean exoskeletons or a mixture of putative microbial remains and crustacean exoskeletons, indicating that the shrimp do not rely solely on chemosynthetic microbes for food. Gut content samples will be further analyzed for stable isotope compositions and possibly molecular identification to develop an understanding of these animals' dietary habits.

\section{Geological Exploration of New Regions}

New areas of exploration included Falkor Rise, Argus

Ridge, Mt. Hudson, and Mt. Emms, and we continued to explore the Mt. Dent OCC (Figure 1). During transects of these areas, ship- and shore-based teams made continuous visual observations, and Hercules collected rock samples for geological study of the OCCs and the Mid-Cayman Rise as a whole. Dives were sited to explore detachment fault surfaces and the more recent high-angle faults that dissect the Mt. Dent OCC. The latter are of interest because they likely provide pathways for hydrothermal fluid circulation. Fault surfaces bounding Mt. Dent and Falkor Rise were successfully imaged and sampled. The samples show that the detachment faults are dominantly brittle, and we collected only a few rocks that recorded ductile deformation. A second major objective was to better understand the distribution of rocks types that make up Mt. Dent on which the Von Damm vent field is built. Samples reveal that Mt. Dent is composed of roughly equal proportions of crustal gabbroic rocks and mantle peridotite, with a veneer of basalt that is perhaps related to late volcanic activity. 


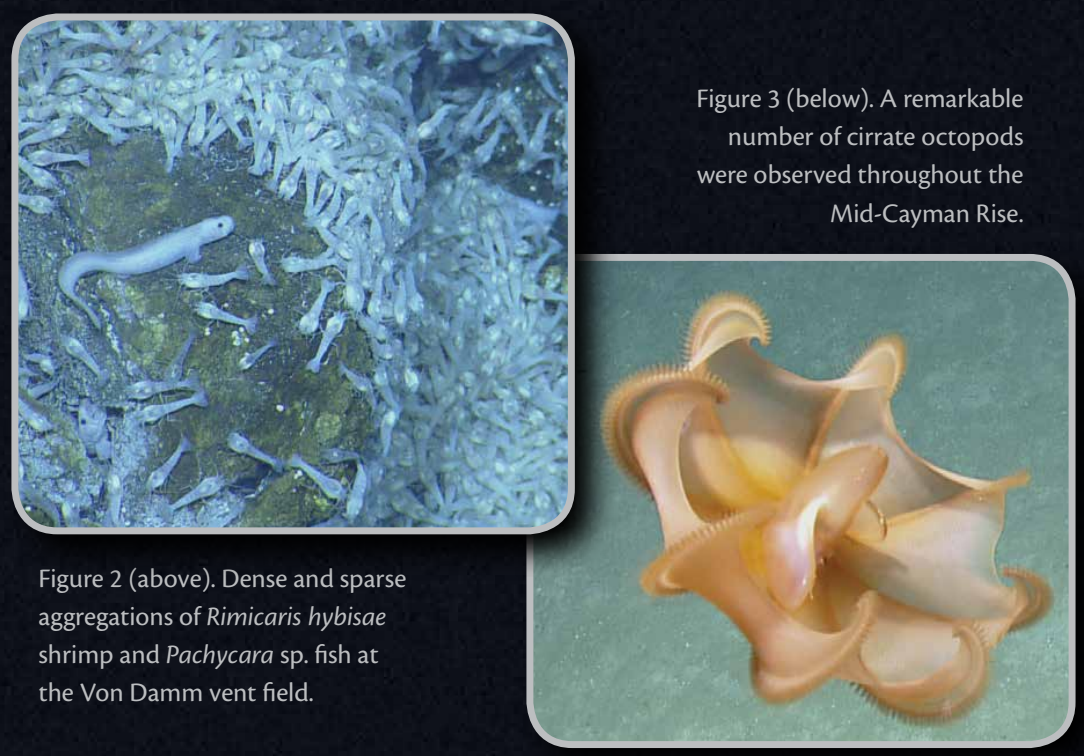

\section{Cirrate Octopods}

Hercules encountered cirrate octopods on nearly every dive during the Cayman cruise (Figure 3). Cirrate, or finned, octopods are also known as dumbo octopods because they swim by flapping their ear-like fins and so look like the cartoon flying elephant Dumbo. Some species are among the largest deep-sea nekton, but cirrates are poorly known. There appeared to be at least three species, two of which are in the family Cirroteuthidae. The most numerous was the "blind octopod" Cirrothauma murrayi.

\section{New, Small, Diffuse Vent Discovery}

Toward the end of the cruise, one of the last dives generated what could be the most exciting result of all, and we made extensive use of our telepresence connections to discuss and direct operations. Building on chemical sensor anomalies that had been detected from an autonomous underwater vehicle survey earlier in the summer led by co-author Chris German, and realizing that the location of those anomalies coincided with an apparent tectonic fracture ripping through Mt. Dent, one Hercules dive was directed upslope from the southern depths of the hillside south of Von Damm. Throughout the dive, our shore-based team kept 24-hour watches to observe the dive and make suggestions for rock samples to be collected along the way. One of the sampling sites close to the previously observed chemical anomalies was found to be covered in a rich array of deep sea corals and, upon closer inspection, to host shimmering fluid flow exiting the seafloor at and around the base of the rocky outcrops.

A $25 \times 40 \mathrm{~m}$ survey of this site employed a high-resolution acoustic and imaging sensor suite described in Roman et al. (2012). The resulting image mosaic and multibeam bathymetry, gridded to centimeter resolution, revealed both geological and biological patterns (Figure 4). In addition, the structured light laser sensor detected diffuse flow venting (Smart et al., 2013), which will advance geological understanding of the site. The high-resolution images also permit documentation of the distribution and type of biological communities, for instance, the location of the corals.

The new questions posed by the discovery of the small, diffuse vent site abound. Is this a new class of hydrothermal flow? Does it occur across the summits of all the OCC hilltops of the Mid-Cayman Rise? Do they also occur on all other slow and ultra-slow ridges (about half of the entire mid-ocean ridge system)? Are they chemically enriched and, if so, (a) what are the implications for global ocean chemistry and (b) can they sustain new forms of life? With that many questions from a single modest site of discovery, we are certain that there is much yet to explore.

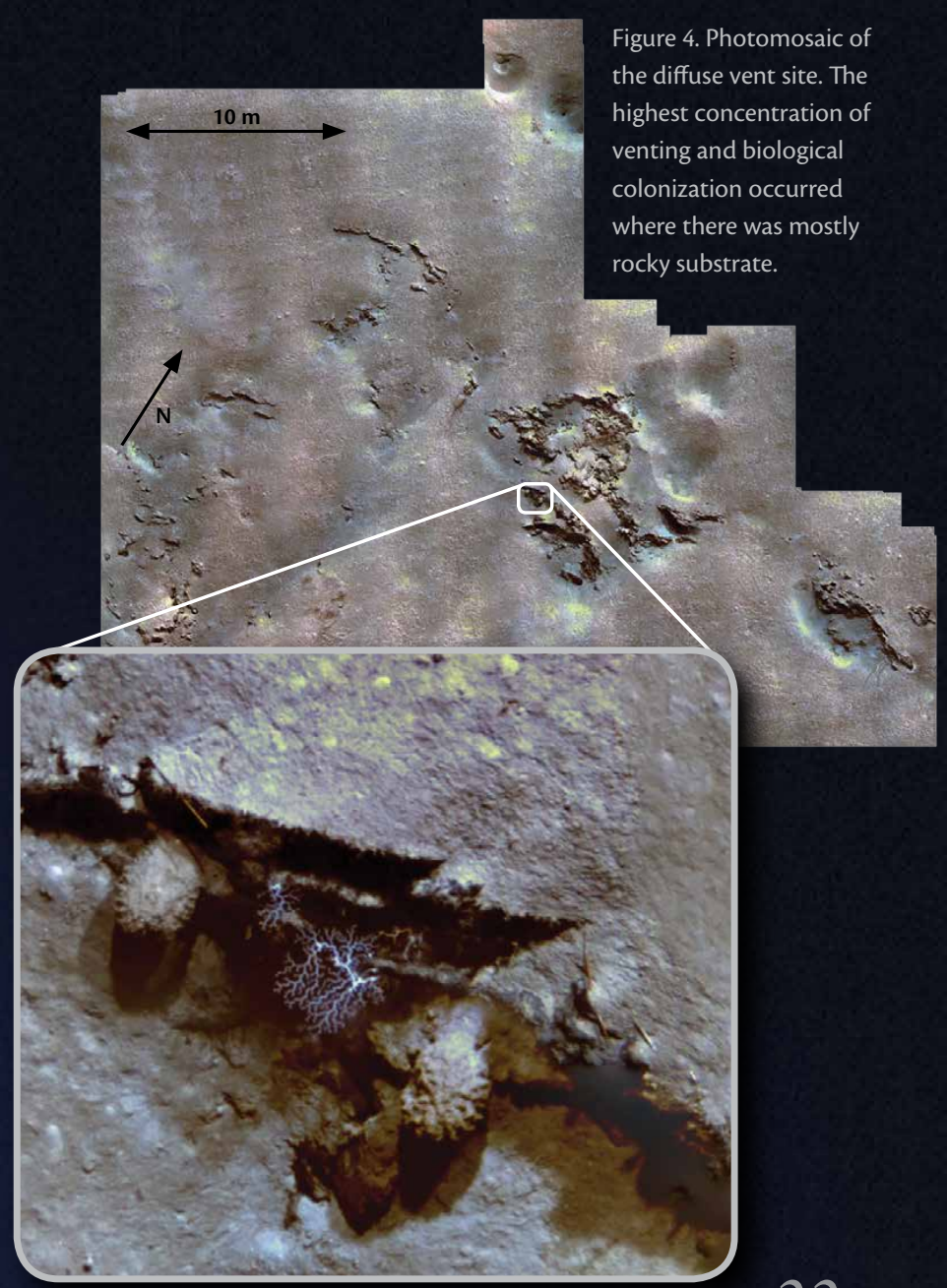


By Uri ten Brink, Dwight F. Coleman, Jason Chaytor, Amanda W.J. Demopoulos, Roy Armstrong, Graciela Garcia-Moliner, Nicole A. Raineault, Brian Andrews, Roger Chastain, Katherine Rodrigue, and Mathieu Mercier-Gingras

Puerto Rico and the Virgin Islands are located at the boundary between the North American plate and the northeast corner of the Caribbean plate (Figure 1), where plate tectonic interactions have caused large magnitude earthquakes and devastating tsunamis. Some of the peculiarities of this plate boundary include an unusually deep trench north of Puerto Rico (the deepest place in the Atlantic Ocean) where subduction of the North American plate is very oblique, an additional fold-and-thrust belt with opposite polarity south of Puerto Rico, and complex deformation zones on the west (Mona Passage) and southeast (Anegada Passage) sides of Puerto Rico and the Virgin Islands (Figure 1).

The Ocean Exploration Trust conducted a multidisciplinary expedition in the Northeast Caribbean from October 4-18, 2013, aboard E/V Nautilus. The primary

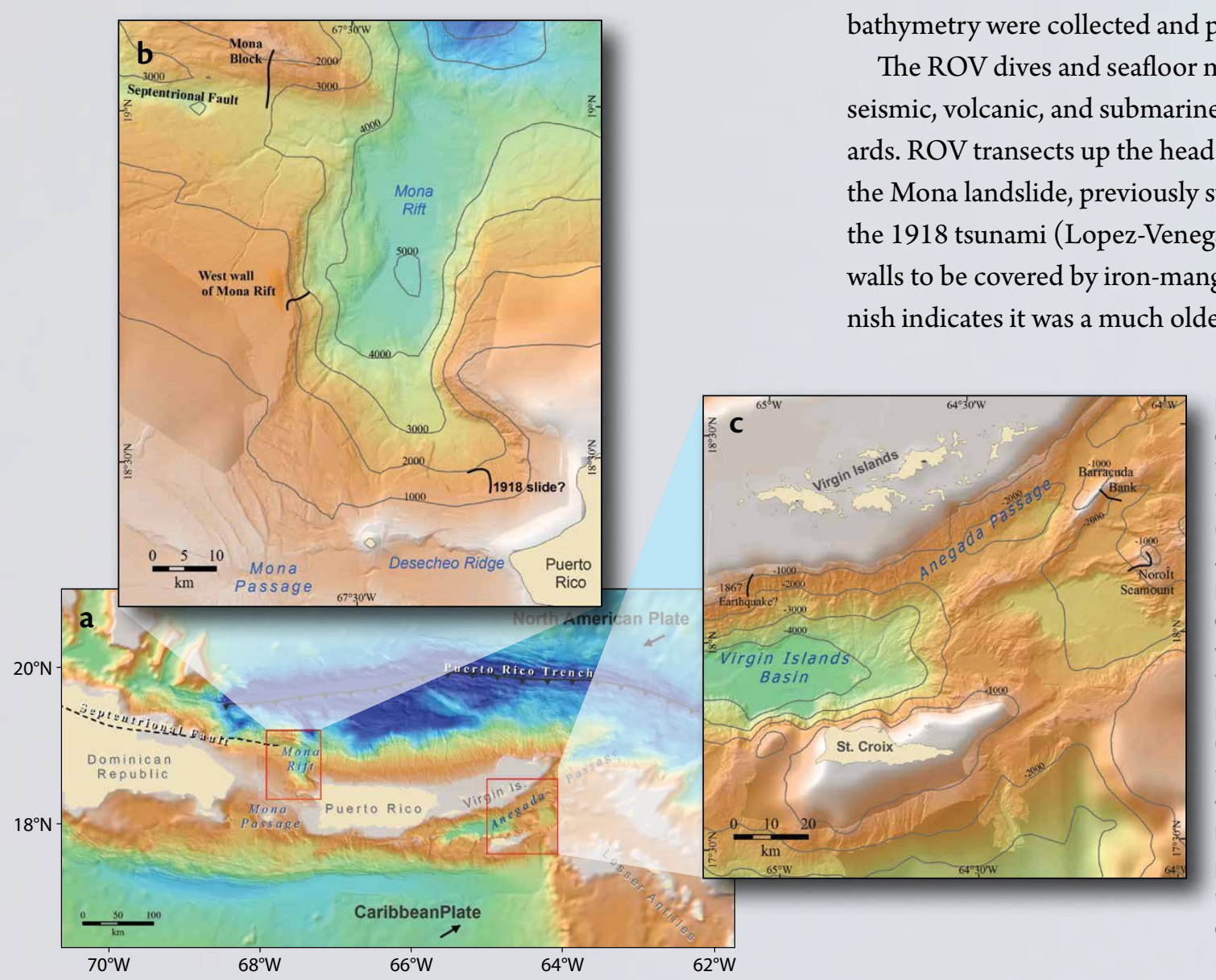
bathymetry were collected and processed on board.

goal of the research cruise was to investigate several previously identified sources of seismic and tsunami hazards in the region and to better understand their timing and activity. Targets included several submarine fault systems, such as those responsible for the 1842 earthquake in Hispaniola (ten Brink et al., 2011), the 1918 earthquake in western Puerto Rico (Mercado and McCann, 1998), and the 1867 earthquake in the Virgin Islands (Barkan and ten Brink, 2010); submarine landslide scars that may have triggered the 1918 tsunami (Lopez-Venegas et al., 2008); and a suspected extinct submarine volcano (Bouysse et al., 1985).

The ROVs spent a total of 4.5 days of seafloor time at seven dive sites in Mona and Anegada Passages. The ship's Kongsberg EM302 multibeam echosounder was used to plan the dive transects and to improve the resolution and coverage of current US Geological Survey bathymetry of the area. A total of 2,028 line-kilometers of multibeam

The ROV dives and seafloor mapping examined specific seismic, volcanic, and submarine landslide potential hazards. ROV transects up the head scarp and a flank scarp of the Mona landslide, previously suggested to have caused the 1918 tsunami (Lopez-Venegas et al., 2008), showed the walls to be covered by iron-manganese varnish. This varnish indicates it was a much older landslide than previously 


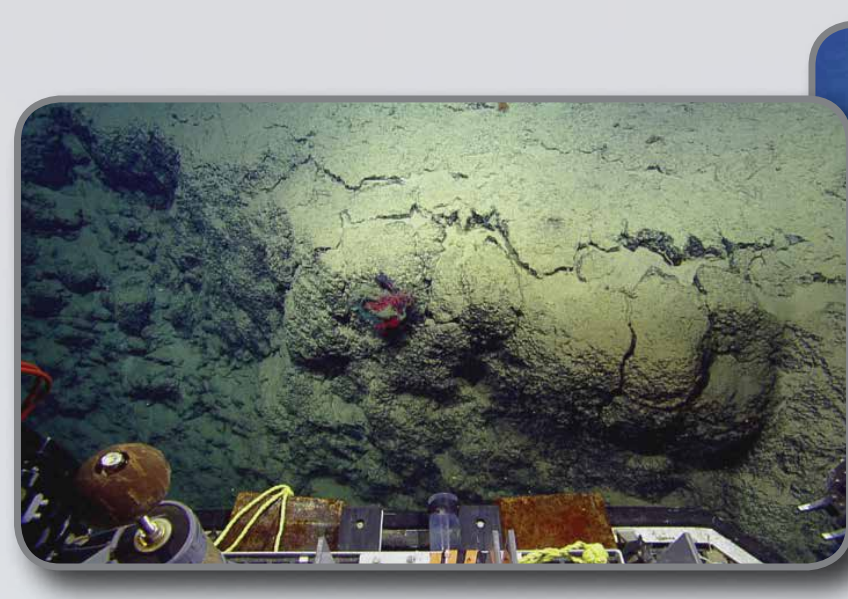

Figure 2. Manganese-coated wall of Mona slide, previously thought to be the source of the 1918 tsunami. Water depth is $1,270 \mathrm{~m}$.

thought (Figure 2). A steep vertical cliff, several hundred meters high, located approximately $20 \mathrm{~km}$ north of the landslide appeared to be fresh, probably caused by a large landslide or a series of smaller incremental ones (Figure 3). We could find no surficial evidence for the eastward continuation of the Septentrional Fault, the major strike-slip fault stretching from Mona Rift to Cuba. Thus, this fault likely presents a smaller seismic hazard to Puerto Rico than previously suggested (Clinton et al., 2006). We also found no evidence of a fresh fault surface running from Desecheo Island into western Puerto Rico. The previously proposed fault trace of the 1867 Virgin Islands earthquake (Barkan and ten Brink, 2010) was found to be associated with a $30 \mathrm{~m}$ high linear and somewhat fresh rock wall. Closer to St. Thomas, the ship's multibeam echosounder mapped another possible fault, cut in places by landslide scars that could be associated with past earthquakes in the area. Noroit Seamount, east of the Virgin Islands, was mapped in detail and verified as a fairly young but inactive volcano. If this seamount is part of the Lesser Antilles volcanic chain, then the chain extends almost to Barracuda Bank in the middle of Anegada Passage, where a steep landslide or fault trace was identified.

Exploration of this region also yielded new insights into the distribution, abundance, and community structure of deep-sea benthic communities, including corals, sponges, other invertebrates, and fishes. Coral abundance (> $500 \mathrm{~m}$ depth) appeared very low compared to canyons in the Northeast US Atlantic margin and the Bahamas region, although their patchy distribution may not be indicative of the broader area. Sponges were found at all sites. Additionally, holothurians (sea cucumbers) were found during all the dives, but were notably most abundant along the north wall of the Virgin Islands Basin, possibly

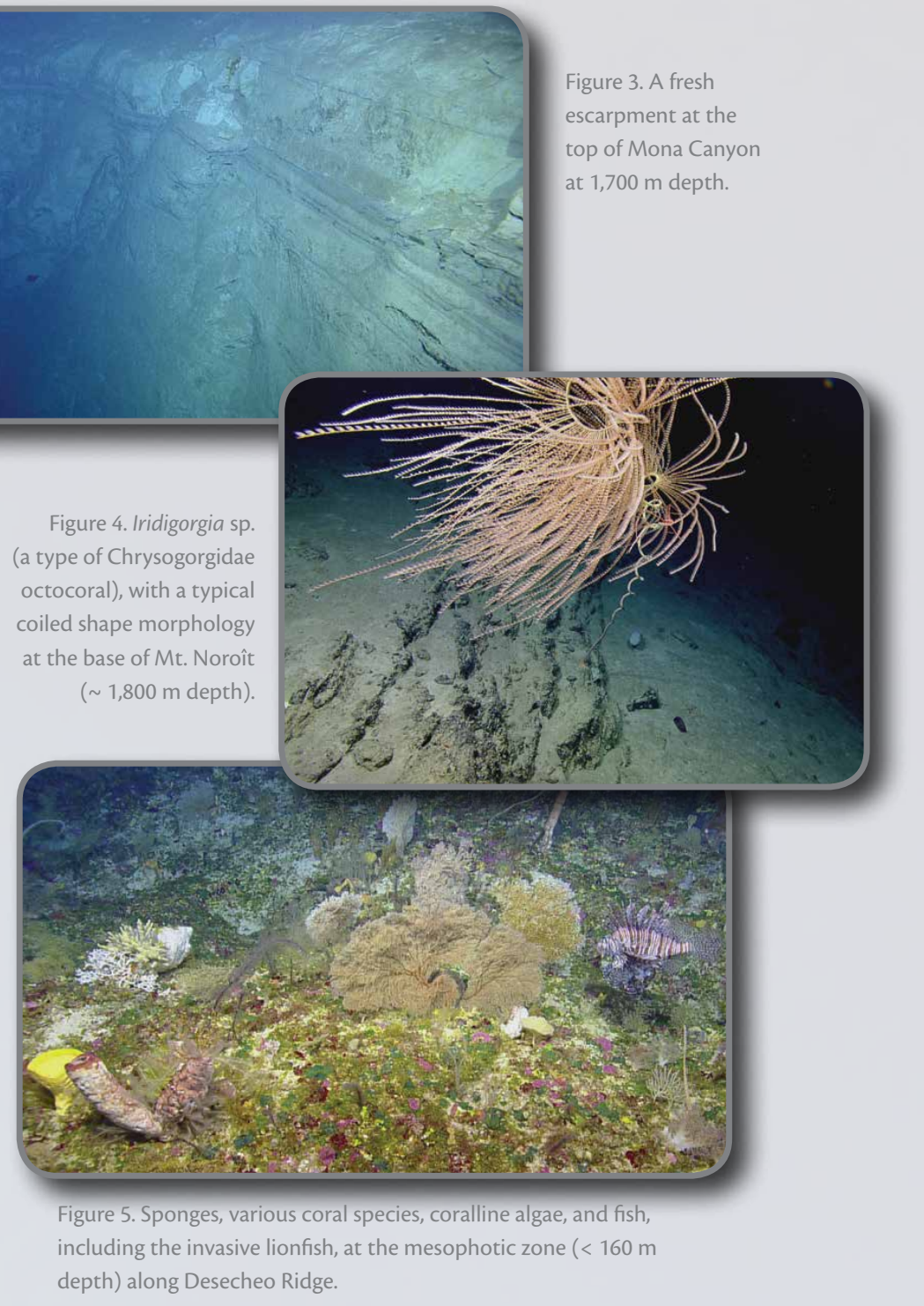

an indication of the highly productive environment in this region. There was no clear distinction between the benthic communities northwest of Puerto Rico (Atlantic Ocean) and the Virgin Islands (transition to the Caribbean). Noroit Seamount stood out in exhibiting complex and diverse communities of benthic organisms; however, given the limited area examined, it is too early to determine species endemism. Large gastropods (sea snails) and the largest primnoid octocorals (corals) were only encountered here (Figure 4). The fish observed during the dives were those known to live at these depths around Puerto Rico (Figure 5). The number of fish were generally low except near Noroit Seamount, where additional species not seen during the other dives were present.

This first deep systematic exploration of the Greater Antilles region has changed our understanding of the geology and geological hazards of the area surrounding Puerto Rico and the Virgin Islands, and provided a glimpse into hitherto unknown deep benthic ecology and fisheries. 


\author{
By Steven Carey, Katherine L.C. Bell, Stephen Sparks, Adam Stinton, Jesse Ausubel, Brennan T. Phillips, \\ Nicole A. Raineault, Nam Siu, Christina Fandel, Omari Graham, Hannah Ramsingh, Ruth Blake, \\ Steven Auscavitch, Amanda W.J. Demopoulos, and Katherine Rodrigue
}

Volcanic activity in the Lesser Antilles island arc

(West Indies) produces large quantities of ash, pumice, and rock that are delivered to the shallow and deep marine environments of the western Caribbean Sea and eastern Atlantic Ocean. On the island of Montserrat, in the northern part of the Lesser Antilles, Soufrière Hills volcano has erupted frequently since 1995 (Figure 1). About $1.1 \mathrm{~km}^{3}$ of andesitic magma (Wadge et al., 2010) has erupted, and much of this material has been transported into the ocean as pyroclastic flows - hot avalanches of rocks, ash, and gas that travel at speeds in excess of $160 \mathrm{~km}$ per hour (Wadge et al., in press). In addition, mud flows (lahars) carrying volcanic debris wash into the ocean during periods of intense rain.

High-resolution bathymetric mapping around Montserrat revealed the importance of volcanic collapses that generate large landslides, known as debris avalanches, as a critical mechanism for transporting large amounts of volcanic material into the marine environment (Deplus et al., 2001; Lebas et al., 2011). Debris avalanches can trigger significant tsunamis, and contribute to the geological

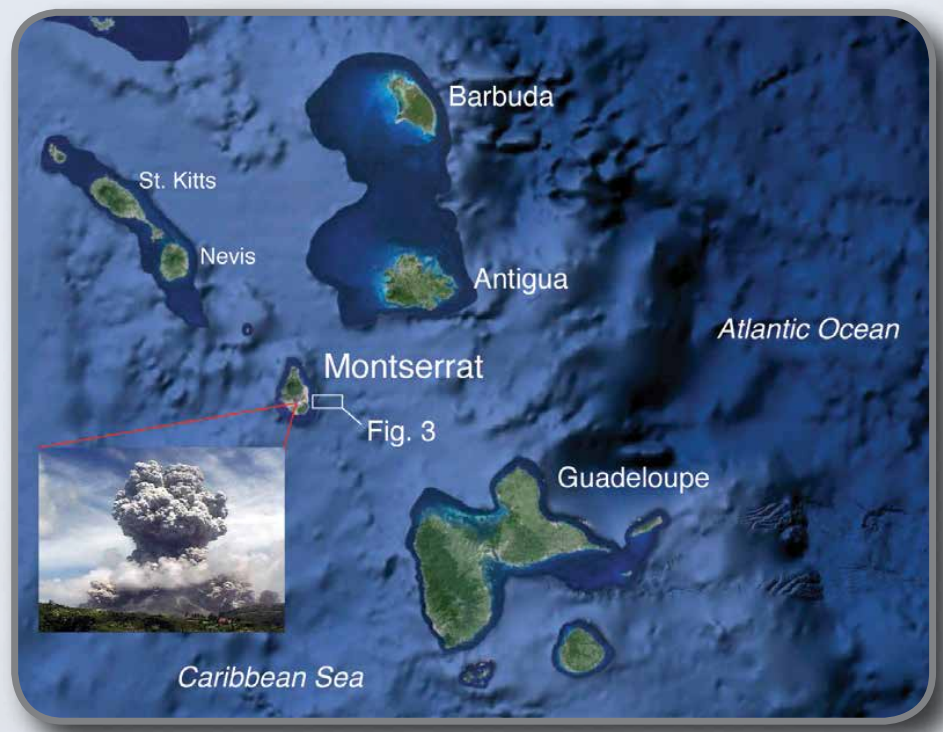

Figure 1. Map of the northern Lesser Antilles island arc showing the location of Montserrat island. Inset photo is an explosive eruption of Soufrière Hills volcano, located in the southern part of Montserrat. hazards associated with this dynamic boundary.

The current volcanic episode includes an eruption on December 26, 1997, that devastated the southwest flanks of Soufrière Hills volcano and razed two villages, sweeping the houses and their contents into the sea. E/V Nautilus investigated the effects of both the recent influx of volcanic material into the sea from the eruption and larger debris avalanche events that took place in the recent geologic past. Effects from discharge of volcanic flows into the sea were found to be localized and related to the flows' intensity/ concentration. A major dome collapse (the largest of any historical dome collapse worldwide) in July 2003 initiated a submarine pyroclastic flow (Trofimovs et al., 2006). Observations of carbonate shelf blocks on the surface of these deposits indicate that the shelf was also destabilized by this event.

In the area offshore of St. Patrick's village, which was destroyed by the 1997 eruption, few effects could be seen in shallow water (100-200 m). Dense colonies of whip corals (Stichopathes sp.) occupy the marine slopes, indicating that volcanic flows had little impact just offshore of the village despite the devastating effect on land (Figure 2a). It is likely that the energetic flows were too dilute to form high-concentration flows that continued downslope into the marine environment. In contrast, only a few hundred meters along the coast toward the capital city of Plymouth, the shallow seafloor has been swept clean of most marine organisms. They have been replaced by coarse deposits of volcanic ash and boulders (Figure $2 b$ ), and repeated lahar deposits over the last 18 years have formed a significant shallow-water deltaic fan. These observations may offer insight into rates of recovery of marine ecosystems as deep as $1,000 \mathrm{~m}$ following extreme geological disturbances.

Previous work identified at least five major debris avalanches around Montserrat, although the ages and sources are poorly constrained (Le Friant et al., 2004). ROV dives focused on sampling and observing individual blocks in the deposits to facilitate correlations with landbased sequences and estimation of the units' ages. East of 
Figure 2. (a) Abundant whip corals (Stichopathes sp.)

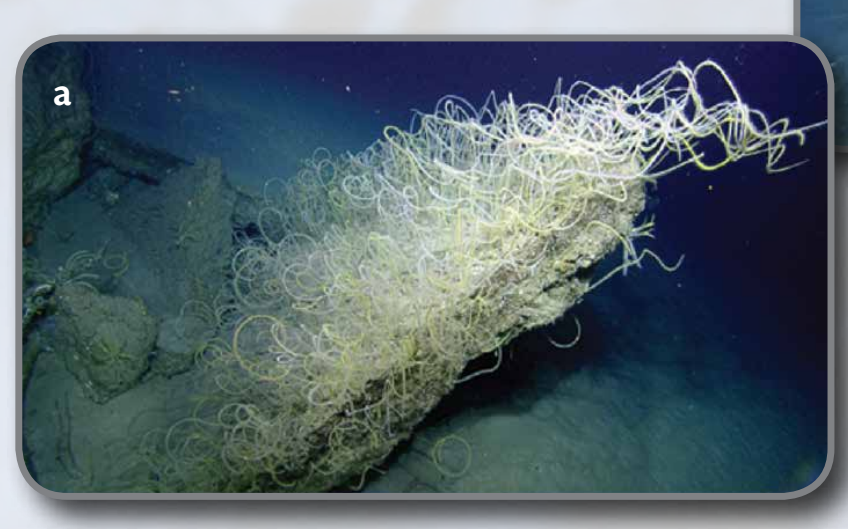

Montserrat, a major debris avalanche (Deposit 1) off the Tar River valley contains some of the largest blocks found on the seafloor (Figure 3). Samples collected from blocks in this area consisted of hornblende-bearing andesite lava typical of the Soufrière Hills volcanic center, hydrothermally altered volcanic rocks, and moderate numbers of carbonate blocks (Figure 4). Exposures on the steep megablock faces show characteristics typical of debris avalanches, with a chaotic mixture of different rock types and domains of intact stratigraphic sequences from the original volcano. The diversity of rock types in Deposit 1 blocks suggest that the collapse originated from a dominantly subaerial volcanic source, but also included parts of the shallow carbonate platform surrounding the island. A possible origin site of this deposit is English's Crater, a large collapse scar in the Soufrière Hills.

In contrast, exploration of blocks in debris avalanche Deposit 5, located to the southwest of Montserrat, revealed sources mainly on the shallow submarine shelf of the island. These blocks contain abundant indurated carbonate rocks displaying karst solution features typical of subaerial weathering and bedded units with highly rounded volcanic boulders and cobbles typical of deposits emplaced in the high-wave-energy coastal zone or derived from discharge of lahars into the sea. These observations support the interpretation of Deposit 5 by Cassidy et al. (2013) as related to large-scale collapse of the southwestern submarine flank of Montserrat 8,000 to 12,000 years ago. A significant discovery of the exploration was the pervasive development of carbonate hard grounds on the western flanks of the volcano at 150-400 $\mathrm{m}$ water depth (Figure 5).
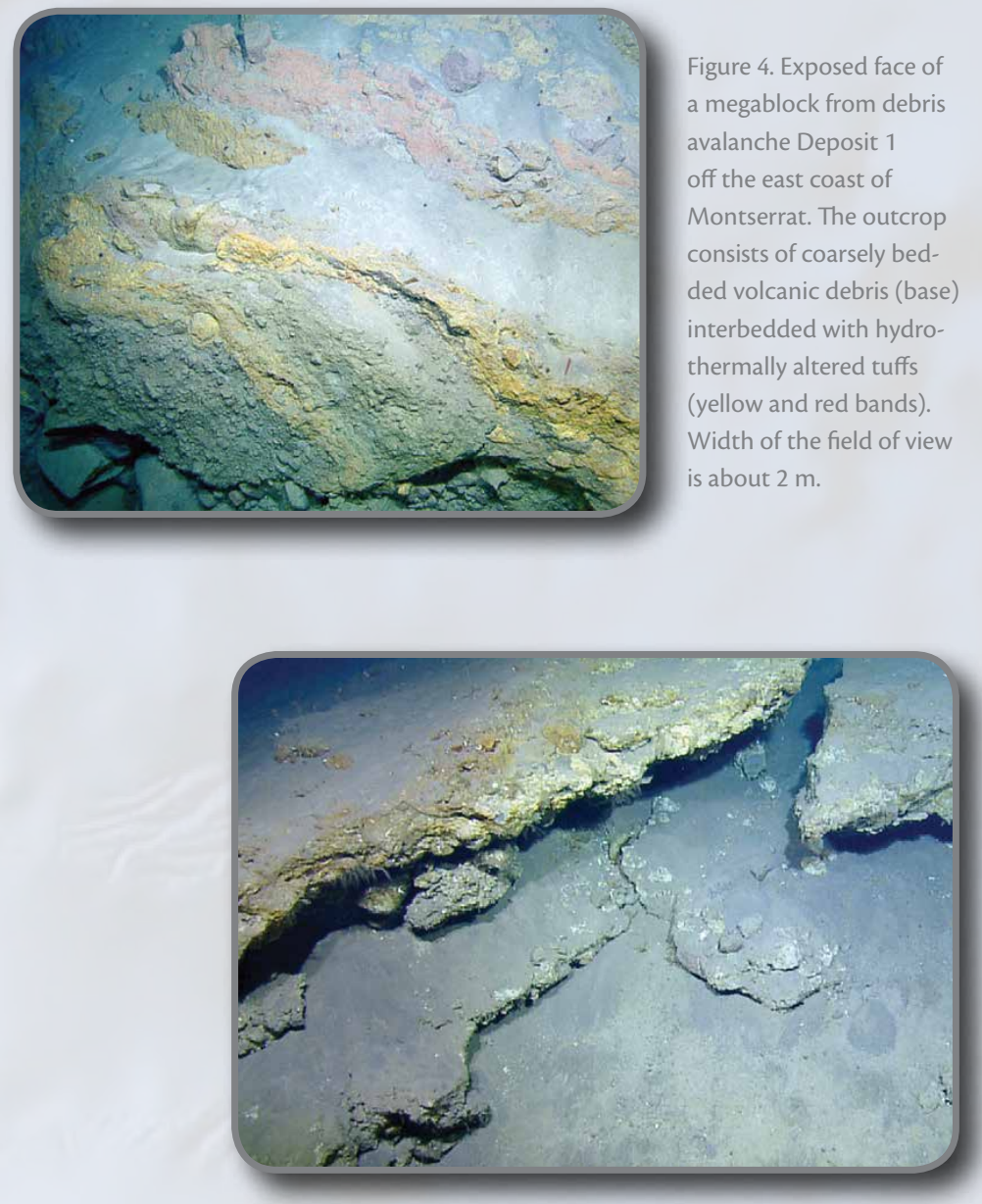

Figure 5. Indurated carbonate crust off the south coast of Montserrat. The crusts are typically several to tens of centimeters thick and consist of cemented biogenic and volcaniclastic material. Red laser dots to the right of center in the image are $10 \mathrm{~cm}$ apart. 


\author{
By Steven Carey, Katherine L.C. Bell, Robert D. Ballard, Christopher Roman, Frederic Dondin, \\ Patricia Miloslavich, Judith Gobin, Brad Seibel, Richard Bell, Clara Smart, Sarah A. Fuller, Nam Siu, \\ Patrick Connally, Ruth Blake, Karen Wishner, and Brennan T. Phillips
}

Kick'em Jenny is the only known active submarine volcano in the Caribbean Sea (Devine and Sigurdsson, 1995). It is located on the western flank of the Lesser Antilles arc just offshore of the island of Grenada (Figure 1). The volcano was discovered in 1939 when numerous earthquakes were felt and accompanying tsunamis affected Grenada, the Grenadines, and as far away as Barbados. There have been at least 11 eruptions since that time, with the last event occurring in 2001. Explosive eruptions can pose a hazard to local island populations (e.g., Dondin et al., 2012) when they breach the sea surface, and shallow-water explosions or edifice collapse can potentially generate tsunamis (Lindsay et al., 2005).

A 2003 detailed multibeam survey conducted from the NOAA Ship Ronald H. Brown revealed new details about the structure of the volcano and the surrounding region. The most striking feature is an arcuate, $3 \mathrm{~km}$ diameter west-facing horseshoe-shaped scarp that surrounds much of the volcanic cone to its south, west, and north. This feature resulted from the collapse of a pre-existing subaerial volcano that produced a large-scale debris avalanche that traveled $14 \mathrm{~km}$ into the Grenada Basin to the west of Kick'em Jenny (Figure 1). Bathymetric mapping during the 2003 Brown cruise also revealed the existence of five small previously unknown submarine volcanoes. Three are conical in shape with well-defined craters, and two have dome-like structures. One of the cones, provisionally named Kick'em Jack, is similar in size to Kick'em Jenny and exhibits a horseshoe-shaped crater with an interior dome.

ROV explorations of Kick'em Jenny's crater floor at $260 \mathrm{~m}$ water depth in 2003 detected high-temperature $\left(>250^{\circ} \mathrm{C}\right.$ ) fluid and gas venting, and discovered a new vent-specific spionid worm living within white bacterial mats and among dead mid-water shrimp (Graff et al., 2008). The venting was occurring predominately within a small depression nested within the volcano's main crater.

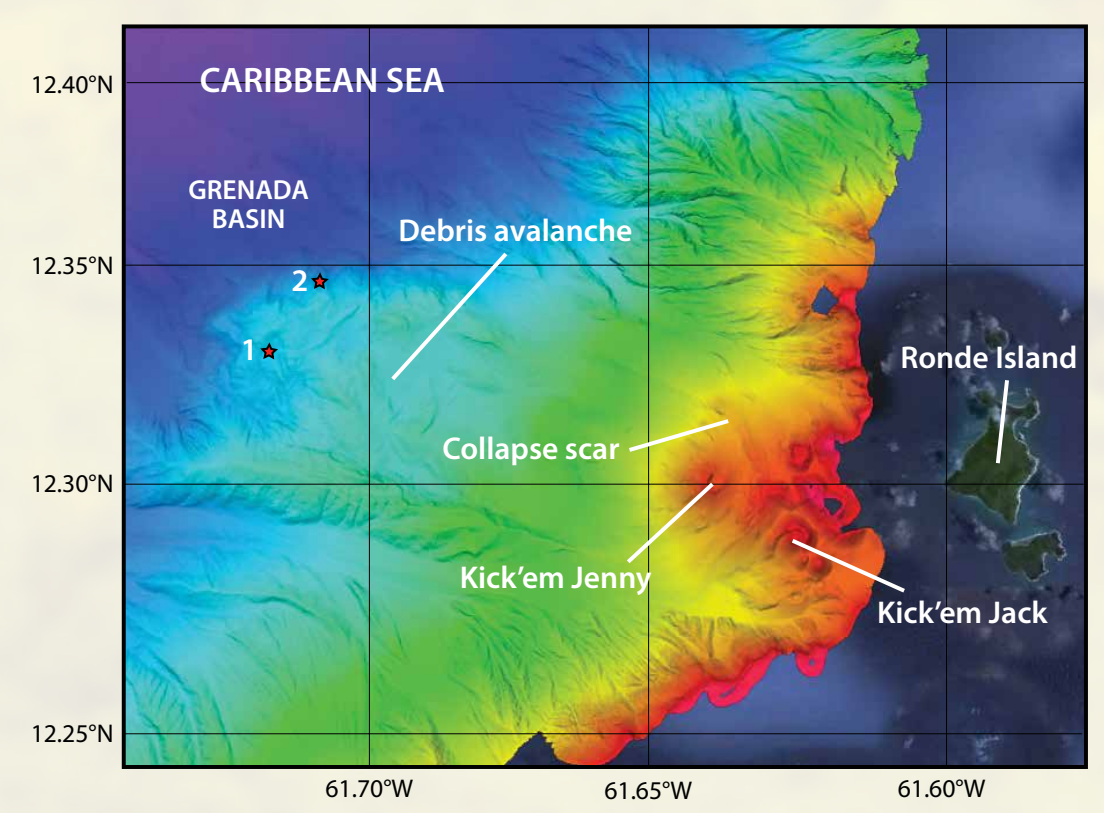

Figure 1. Map of the southern Lesser Antilles region showing the location of Kick'em Jenny submarine volcano. A horseshoe-shaped collapse scar that opens to the west toward the Grenada back-arc basin surrounds the volcanic cone. Stars indicate the locations of the two cold seep areas at the distal end of the Kick'em Jenny debris avalanche. The white line at Kick'em Jack volcano points to the location of a prominent lava spire. Bathymetry collected during a multibeam survey on cruise NA039.

\section{Kick'em Jenny Crater}

E/V Nautilus returned to Kick'em Jenny in 2013, 10 years after the last detailed exploration there. The objectives of the cruise were to assess the hydrothermal system in the volcano's crater and the biological communities associated with it; collect samples of gases, fluids, volcanic rocks, and some of the organisms; study the nature of the debris avalanche deposit in the Grenada Basin; and explore the other submarine volcanoes in the area.

New ROV explorations of the crater revealed several types of fluid and gas venting. Large areas of the crater were covered by reddish/ orange iron oxides, providing evidence of lowlevel diffuse flow. These iron oxides were produced by bacteria that formed mats and small mounds on the seafloor (Figure 2). White and whitish-gray microbial mats also occurred at the orifices of some vents. 
Zones of more focused flow often occurred along the margins of the inner crater where venting sites featured 1 to $2 \mathrm{~m}$ high iron-oxyhydroxide spires/chimneys (Figure 3). The extremely fragile spires had internal temperatures up to $55^{\circ} \mathrm{C}$. The highest temperature venting also occurred along the margins of the inner crater and at some small mounds on the crater floor where both shimmering water and gases were observed. The maximum temperature measured in a gas and fluid vent on the inner crater wall was $180^{\circ} \mathrm{C}$. At a vent nicknamed "Champagne" on the inner crater floor, two different types of gases were being discharged (Figure 4). At the vent's highest point, the bubbles appeared translucent and whitish, whereas gas discharged nearby on the same mound exhibited clear bubbles. Observations suggest that the whitish color may have resulted from condensation inside the bubbles due to rapid temperature change. Samples of each gas type collected using pressure-tight cylinders will be analyzed as part of post-cruise research. We suspect that the gases may be carbon dioxide, as observed at other shallow submarine volcanoes in subduction zone environments (e.g., Carey et al., 2013), or sulfur dioxide and perhaps methane. Flux of $\mathrm{CO}_{2}$ from hydrothermal vents can contribute to local seawater acidification, and $\mathrm{pH}$ measurements as low as 4.9 at the Champagne vent suggest that $\mathrm{CO}_{2}$ may be bubbling out of Kick'em Jenny crater.

In general, the diversity and abundance of macrofauna surrounding the vents within the crater was relatively low. Notable residents included echinoids and cerianthid anemones, as well as moray eels, snowy grouper, torpedo rays, and greater amberjacks. During the 2003 cruise, many dead and comatose shrimp were observed around the active venting areas. These shrimp (three species) were not vent-specific taxa, but rather were typical mid-water animals thought to have been trapped by toxic vent conditions during diel vertical migration (Wishner et al., 2005). In contrast, the 2013 dives found live shrimp, some with eggs, living in burrows within the upper few centimeters of sediment on active vent sites (Figure 5). Preliminary examination suggests that they might be the vent-specific shrimp, Alvinocaris sp. This vent also had a relatively abundant polychaete population of the Spionidae family along with sipinculid species living within the sediment. No dead diel vertical migrators were seen on the seafloor.

The high-resolution, multisensor mapping system on ROV Hercules includes a Blue View multibeam sonar,
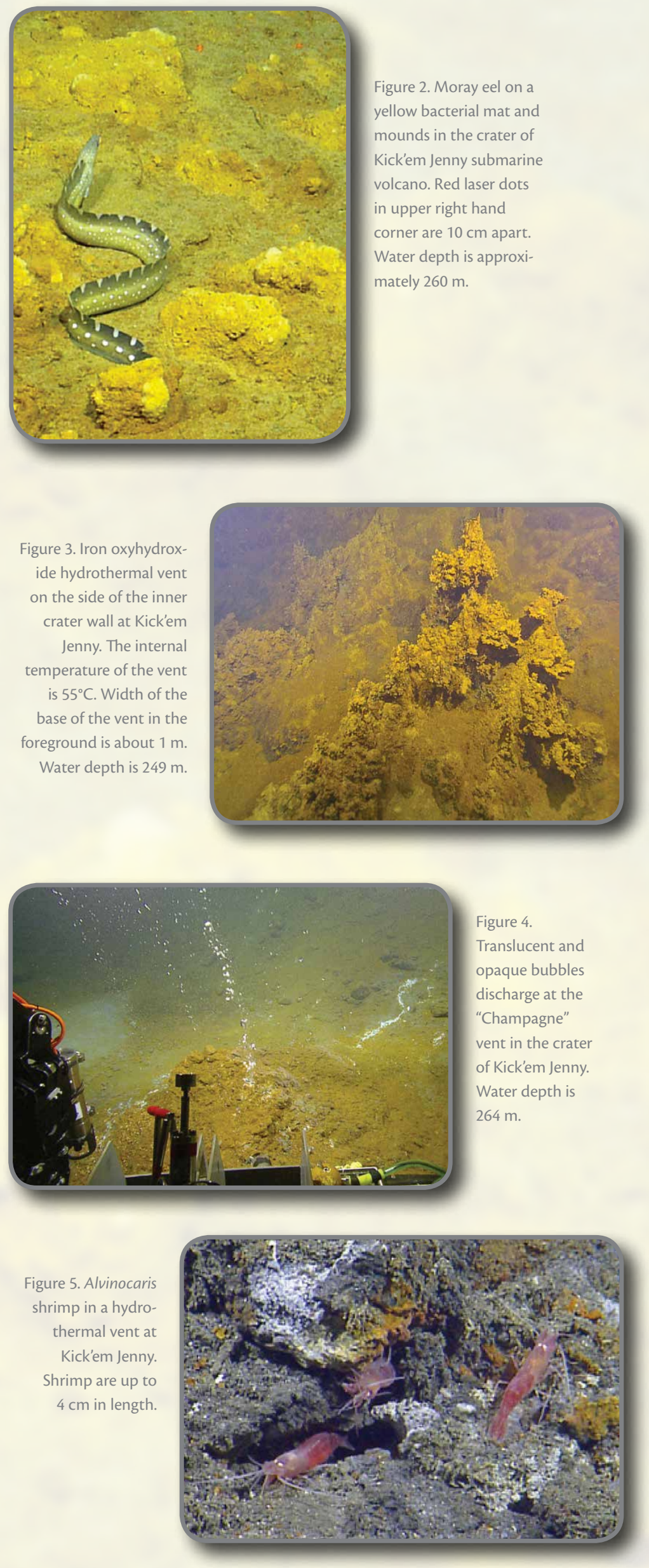


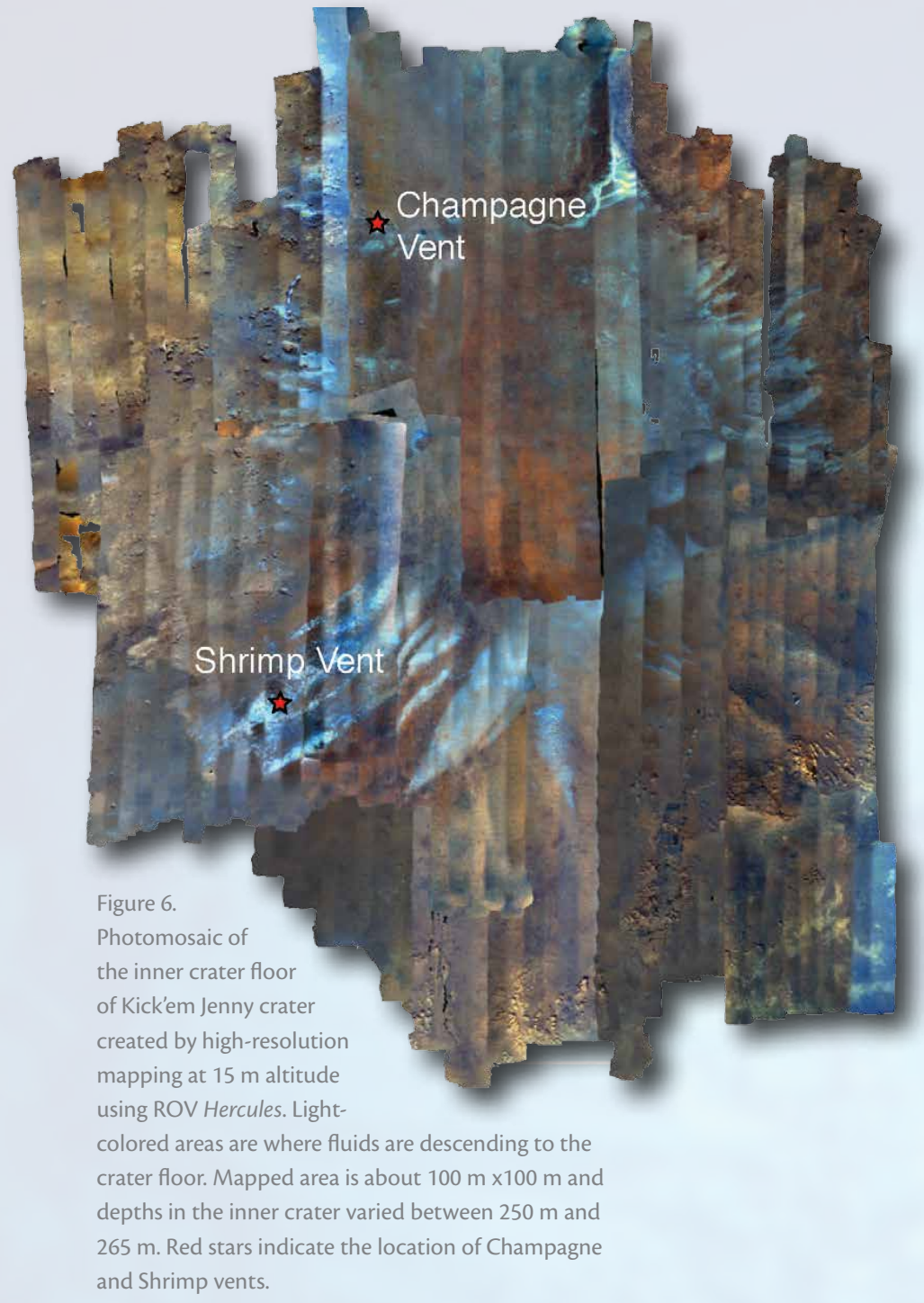

stereo cameras, and a structured light laser capable of digitally documenting the seafloor at centimeter-level resolution (Roman et al., 2013). It was used to map and image the inner crater region (100 m x $100 \mathrm{~m}$ ), allowing for effective visualization of the venting areas as defined by the occurrence of white and reddish/orange bacterial zones (Figure 6). The majority of venting appears to be focused along the steeper walls of the inner crater in areas that may provide more porous pathways for fluids to escape. In addition, post-cruise processing of the structured light laser images will be used to detect all areas of diffuse flow within the crater and quantify the total contribution of diffuse versus focused flow (e.g. Smart et al., 2013). The vertical range and regional extent of the hydrothermal fluid plume inside the crater was characterized using a pair of NOAA/PMEL "MAPR" instruments, which detected a strong redox potential and an optical backscatter gradient in the $200-250 \mathrm{~m}$ range that was pervasive inside the crater.

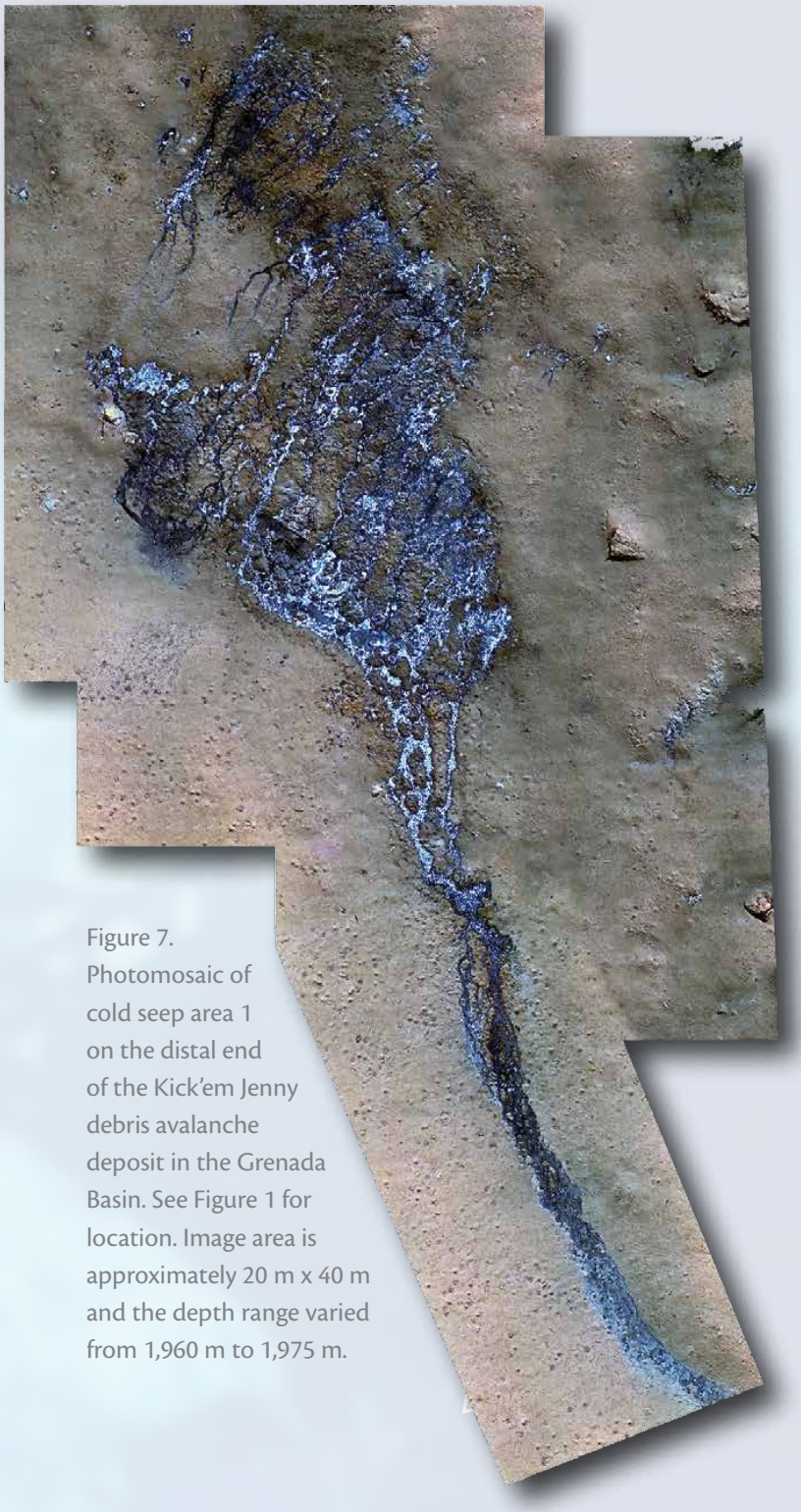

\section{Cold Seep Discovery}

One of the most significant discoveries of this field season was the occurrence of active cold seep vents at the distal margin of the Kick'em Jenny debris avalanche deposit in Grenada Basin. The distal surface area of the debris avalanche deposit is characterized by hummocky morphology and common steep exposures of well-bedded, soft, hemipelagic sediment. During ROV explorations, two areas of distinct fluid venting were observed on steep sediment outcrops. Both areas showed an anastomosing pattern of downslope flow defined by zones of sediment erosion and bacterial colonization (Figure 7). A localized, nonbuoyant redox potential plume was measured at both seeps with the NOAA/PMEL MAPR's. Chemosynthetic biological communities were found in both areas, although macrofauna covered only of a small proportion of the total seep areas.

At the first site (star labeled 1 in Figure 1), the principal sessile organisms were dead clams and polychaetes (including tubeworms). The second site (star labeled 2 in Figure 1) 
was more extensively colonized with sessile organisms, including mussels with commensal-scale worms, clams, gastropods, crinoids, anemones, shrimp, and polychaetes (including tubeworms). Mobile macrofauna, including octopods, holothurians, crabs, ophioroid seastars, and fishes were present at both locations; shrimp were also present at the second site. Of particular interest at the second site was the large number of live giant mussels with commensal-scale worms (Figure 8). Based on gross morphology and known species in the region, the mussels are most likely Bathymodiolus boomerang, B. heckerae, or a member of a newly discovered species in the Gulf of Mexico that has a similar morphology (Charles Fisher, Penn State, and Erik Cordes, Temple University, pers. comm., January 23, 2014). Bathymodiolins are the largest mussels ever found in the world and the maximum size of a specimen recovered on this cruise was $34 \mathrm{~cm}$ in length. Their large size may be attributed to their great longevity in a chemosynthetic environment spanning centuries or more (though the age of the Kick'em Jenny habitat is unknown), in combination with high growth rates when venting conditions are favorable.
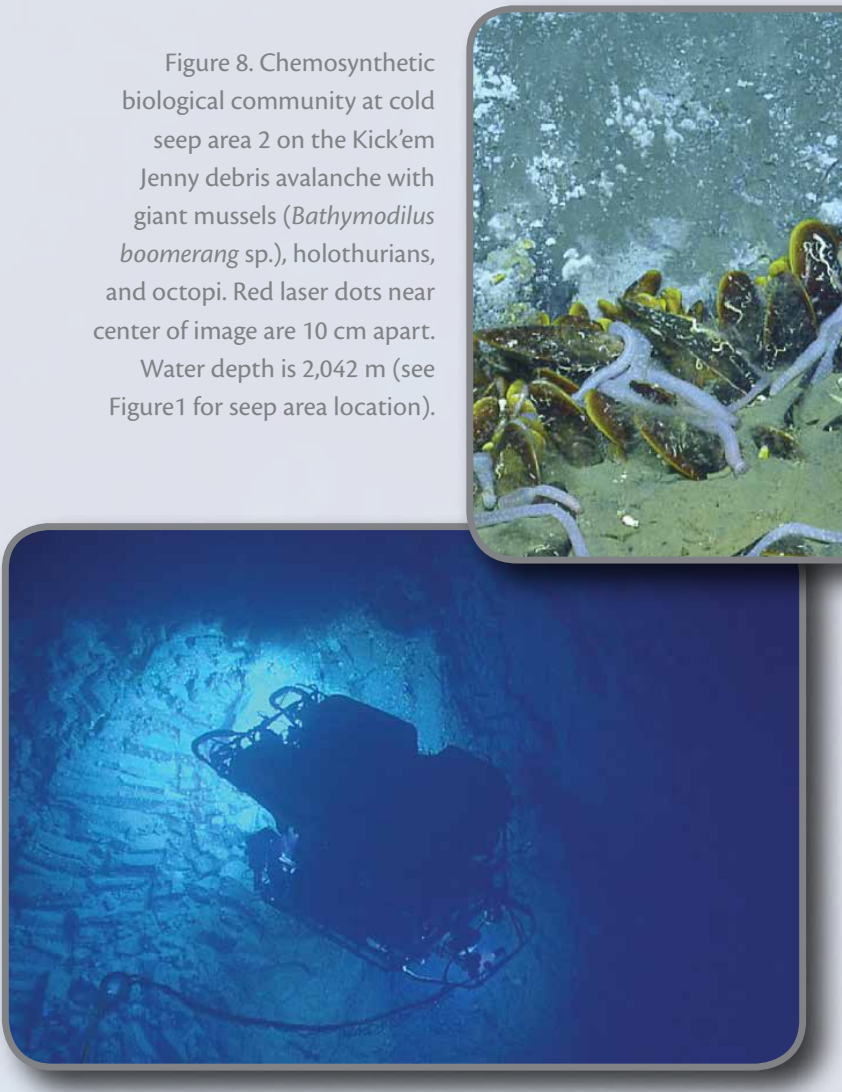

Figure 9. ROV Hercules ascending the vertical walls of a lava spire in the crater of Kick'em Jack submarine volcano. Horizontal cooling joints in the lava can be seen in the left side of the image. Water depth is approximately $180 \mathrm{~m}$.
The occurrence of cold seeps within a volcanic debris avalanche is unusual and not previously reported. Their formation at Kick'em Jenny may be related to soft sediment deformation at the front of the debris avalanche, analogous to processes in forearc accretionary prisms or to fluid overpressure generated in sediments that have been loaded as a result of debris avalanche deposition. Kick'em Jenny appears to be unique in that it is a single volcanic system that exhibits the spectrum of chemosynthetic environments, from hot vents to cold seeps.

\section{Extinct Volcanoes}

Exploration of the other submarine volcanoes adjacent to Kick'em Jenny revealed spectacular underwater lava flow formations resulting from eruption of highly viscous magma. These spires, or pitons, are known from subaerial eruptions in the Lesser Antilles, but this is the first time that they were explored underwater. One spire, located within the collapse crater of Kick'em Jack volcano, was over $100 \mathrm{~m}$ high with near vertical walls. The sides exhibited radial cooling fractures with distinct polygonal shapes (Figure 9). The top of the spire was adorned with a large collection of brightly colored deep-sea corals that were presumably taking advantage of the enhanced current flow supplying planktonic food (Figure 10). No recent activity was identified in the submarine cones around Kick'em Jenny, though there was some evidence of low-level diffuse hydrothermal flow in the area between Kick'em Jenny and Kick'em Jack.

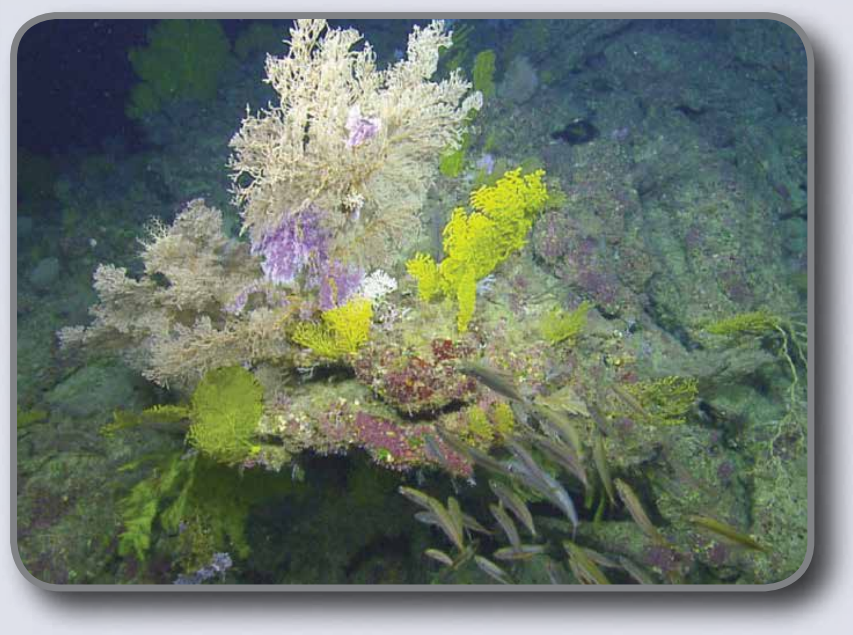

Figure 10. Mesophotic coral and encrusting red algae on the summit of the lava spire in the crater of Kick'em Jack submarine volcano. Water depth is $108 \mathrm{~m}$ (see Figure 1 for spire location). 


\title{
A Portable, Education-Focused Approach to Exploration in the Aegean Sea
}

\author{
By Michael L. Brennan, Arthur C. Trembanis, Dan Davis, Allison Fundis, Val Schmidt, Carter DuVal, \\ W. Benjamin Ballard, Kelsey Cornwell, Daniel Faas, Muhammet Duman, and Tufan Turanlı
}

We returned to the southern Aegean coast of Turkey off ancient Knidos, where Nautilus had worked for the past four years, because of our long legacy there and our interest in continuing archaeological research. The daily operating costs of large research vessels such as Nautilus are prohibitive to systematic, comprehensive, high-resolution acoustic surveys of large areas. This year, we operated off the sail training ship Bodrum (Figure 1) using the small modular autonomous underwater vehicle (AUV) Dora. Both the AUV and STS Bodrum were new exploration platforms for the Nautilus Exploration Program this season, and this pilot study allowed us to develop safe and effective methods for using these assets to conduct exploration and educational activities simultaneously.

The area off Knidos is relatively flat beyond the shelf break, with a shallow slope that permits safe operations for vehicles in water depths of 200-600 m. Outcrops of carbonate crusts from extinct cold seeps, numerous shipwrecks due to high seafaring activity in ancient times, and areas of heavy bottom trawl damage make this submarine landscape

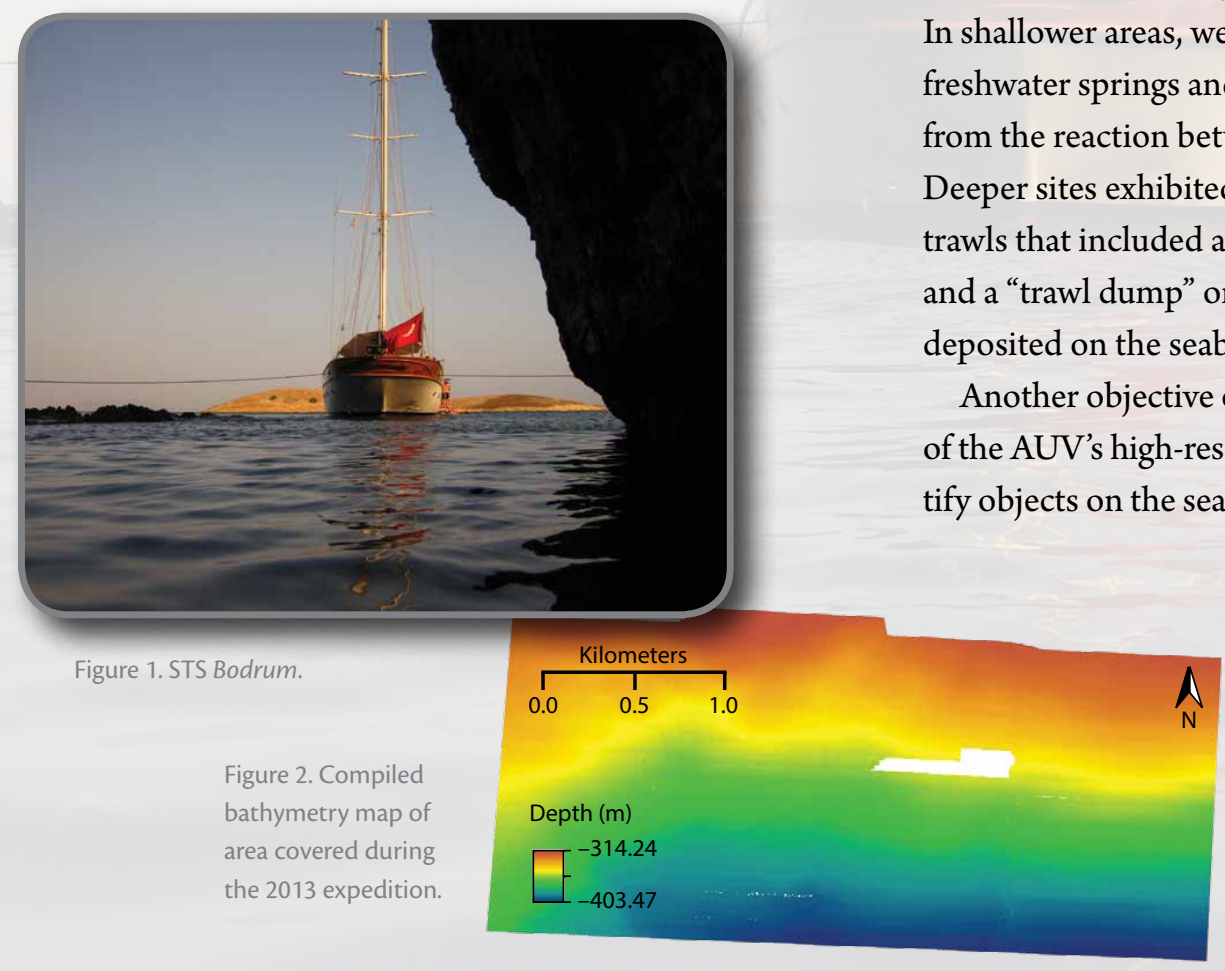

a complex and intriguing area to map and also a good field site for comparing the AUV's capabilities with data collected previously using side-scan sonars towed from Nautilus.

Dora is a $1,000 \mathrm{~m}$ depth rated Gavia AUV equipped with a $900 / 1,800 \mathrm{kHz}$ side-scan sonar, $500 \mathrm{kHz}$ phase measuring bathymetric sonar, and DVL-aided INS positioning system, allowing it to conduct textural mapping and bathymetric mapping simultaneously. We used Dora to map an area of seabed ranging from $200-400 \mathrm{~m}$ depth where there are a few known shipwreck sites. The single battery module endurance for Dora is about three hours, so we divided the survey area up into a grid of twelve $\sim 750 \mathrm{~m} \times 1,000 \mathrm{~m}$ boxes that could be mapped in a single battery pack mission. The AUV was launched in shallow water $(\sim 60-100 \mathrm{~m})$ and programmed to follow a path downslope, bottom tracking from an altitude of $10 \mathrm{~m}$ above the seabed. The combined acoustic coverage of the 10 missions conducted in these grids is nearly $8 \mathrm{~km}^{2}$ (Figure 2 ).

The map provides not only the acoustic texture and bathymetry for this region, but also a complete look at the features on the seabed, which to date had only been documented on a fragmentary basis with earlier surveys. In shallower areas, we found pockmarked sediment from freshwater springs and areas of carbonate crusts formed etween released methane and seawater. bited swaths of seabed scraped by bottom trawls that included a lost trawl door and chain (Figure 3a) or area where sediment and objects are seabed after a trawl is raised (Figure $3 b$ ).

of this project was to assess the ability -resolution sonars to locate and idenpreviousy previously known ancient wreck sites, we also found what may be two new shipwrecks, named Knidos AA and $A B$ (Figure 4a,b). Although we were unable to visually confirm the identity 


\section{a}

or dates of these wrecks, the resolution of the $1,800 \mathrm{kHz}$ side-scan sonar was high enough to show individual amphoras on the sites. The sonar data collected during this expedition will be used to assess the acoustic properties of the sediments in this area as well as to identify morphologic features that change the physical properties of the seabed, such as pockmarks and trawl scarring, building on the conceptual framework laid out by Brennan et al. (2012).

In addition to the science objectives of the expedition, we also used STS Bodrum as a teaching ship. We had four high school students, two educators, and four undergraduate and graduate students on board. Students and educators performed a variety of direct and mission-critical tasks during the expedition, including AUV mission planning, vehicle launch and recovery, and data analysis and interpretation. They also worked together before and during the expedition to conduct research related to the history of the region and to develop an algorithm that solved a mission planning challenge involving efficient surveying of multiple target sites.

For broadcasting the expedition off the ship, we did not have the kind of live ROV video streams that Nautilus and other ships of exploration do. Instead, we used a Twitter feed supplemented by field updated blogs and photo/video updates on the Exploration Now website, http://www.explorationnow.org. The entire science team contributed to a live presence on the expedition website and through social media platforms, including Twitter, Vine, Flickr, and

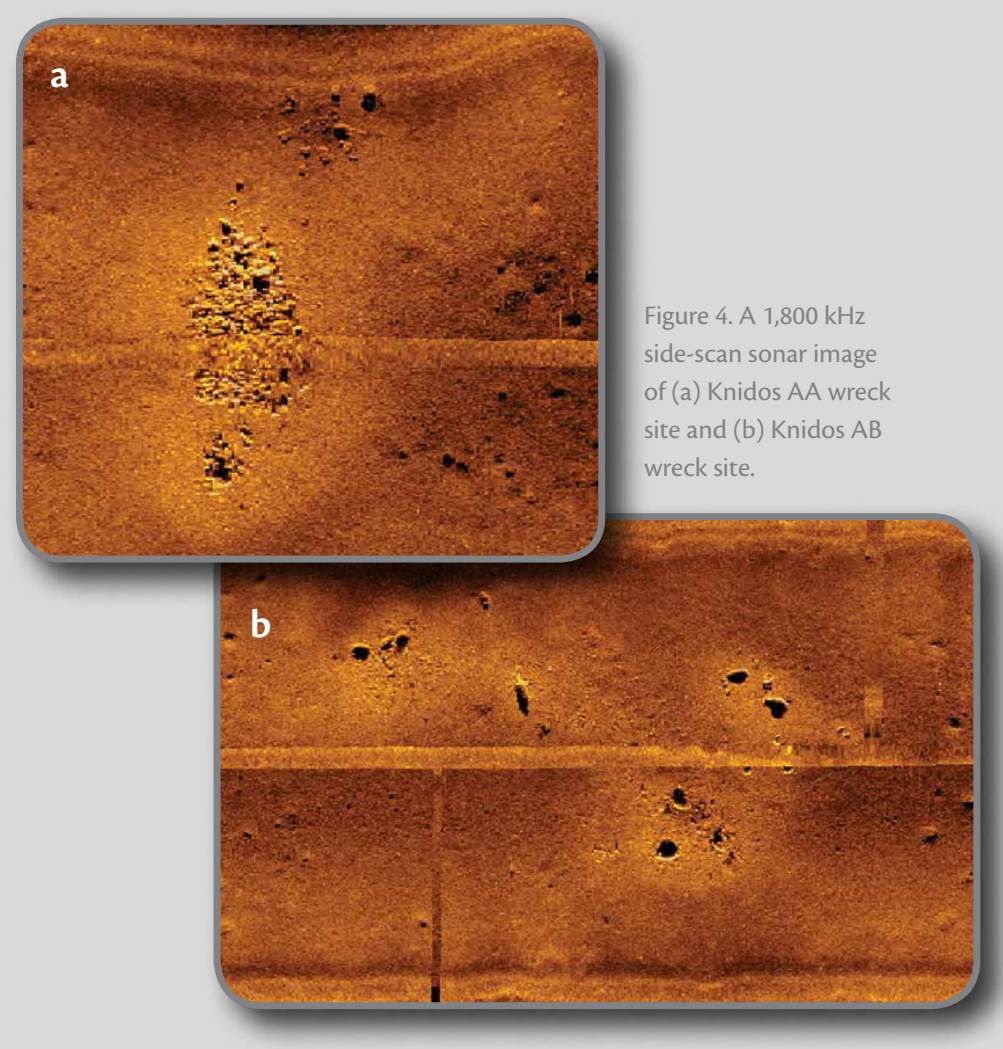

Instagram. Daily posting of edited videos, images, and blogs written by almost every member of the onboard team created a content-rich website that can be used as a model for other field projects that do not have access to high-bandwidth ship-to-shore connectivity. 


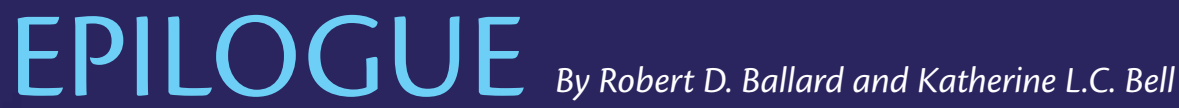

As this publication goes to press, E/V Nautilus is standing down at the University of South Florida's marine facility in St. Petersburg, undergoing its fifth round of improvements. Thanks to friends of the Ocean Exploration Trust, it will involve the complete renovation of the ship's Data Lab and Satellite Room to create a new 167-square-meter (1,800-square-foot) Data Processing \& Visualization Laboratory.

Following a successful series of 2013 expeditions, June 2014 will usher in a four-month field season as we continue to follow the recommendations of the 2012 Workshop on Telepresence-enabled Exploration of the
Caribbean Region. This year, we anticipate projects on the Mesoamerican Reef, in the Windward Passage, spanning several sites in the eastern Caribbean, and extending to the Barbados accretionary prism in the Atlantic Ocean. Keep a weather eye out for opportunities to participate in all of those cruises as we continue to grow our Scientist Ashore program through the OET website, http://www.oceanexplorationtrust.org.

In order to continue improving our scientific telepresence capabilities and to enable more scientists to participate in expeditions as they happen, we have recently been awarded a grant through the Integrated NSF Support 

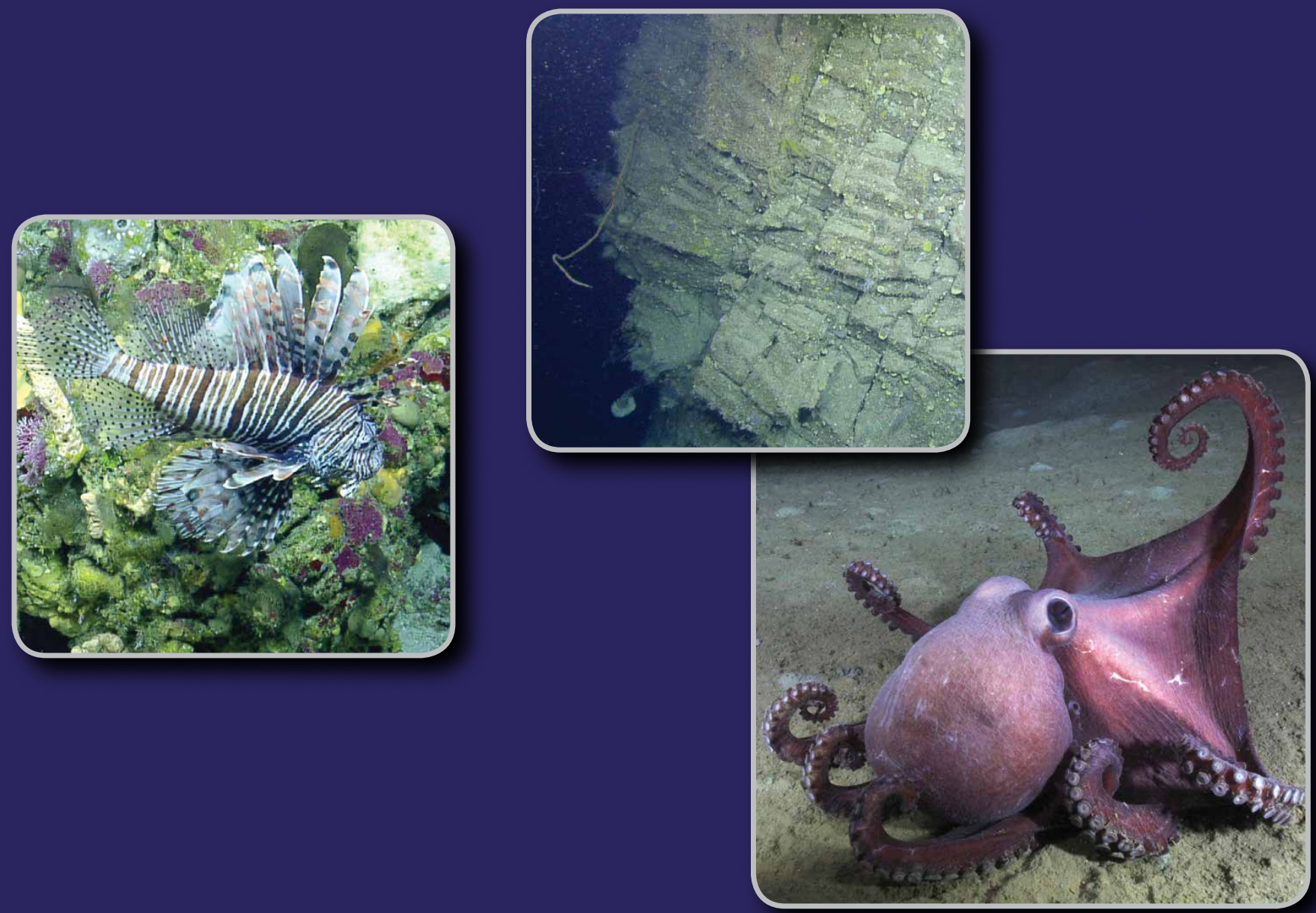

Promoting Interdisciplinary Research and Education (INSPIRE) initiative, in collaboration with co-principal investigators Chris German of the Woods Hole Oceanographic Institution, Zara Mirmalek of Harvard University, Amy Pallant of the Concord Consortium, and Kanna Rajan of the Monterey Bay Aquarium Research Institute. This project seeks to make important inroads into the mechanisms by which remote human-robotic interactions can be used to transform the future of research and how they can be leveraged to advance research experiences for early career scientists and students. We look forward to reporting on the results of this study in next year's Oceanography supplement.

We have also recently been awarded a grant from the Richard Lounsbery Foundation to hold another workshop on telepresence-enabled exploration, this time focusing on the eastern Pacific Ocean. This workshop will be held in December 2014, immediately preceding the Deep Submergence Science Committee and American Geophysical Union annual meetings in San Francisco. In
March 2014, we will issue a call for white papers in order to select participants for this workshop. Information on the workshop will also be posted on the OET website.

This workshop will be designed to prepare for the first Nautilus work in the Pacific Ocean in 2015, as well as to support exploration by NOAA Ship Okeanos Explorer, which is exploring the Exclusive Economic Zone and Extended Continental Shelf offshore the contiguous United States. It may also be useful to the operators of $\mathrm{R} / \mathrm{V}$ Sikuliaq, who have expressed interest in installing telepresence systems on one of the newest Pacific-based UNOLS vessels.

In 2015, Nautilus will continue its long circumnavigation of the globe. Thus far, the journey has taken us from the Mediterranean Sea, across the Atlantic Ocean, and into the Gulf of Mexico and Caribbean Sea. By the end of 2015, we will transit the Panama Canal and begin to work in the Pacific Ocean, with the long-term goal of exploring the US Territorial Trust Islands of the western Pacific Ocean. 


\section{AUTHORS}

DIVA AMON is a graduate student at the National Oceanography

Centre, University of Southampton, Southampton, UK

BRIAN ANDREWS is Marine Geographer, Woods Hole Science Center,

US Geological Survey, Woods Hole, MA

ROY ARMSTRONG is Professor, Department of Marine Sciences,

University of Puerto Rico at Mayagüez, Mayagüez, Puerto Rico

JEAN-MARIE AUGUSTIN is an engineer, Département Infrastructures

Marines et Numériques, IFREMER, Plouzané, France

STEVEN AUSCAVITCH is a graduate student in the School of Marine

Sciences, University of Maine, Orono, ME

JESSE AUSUBEL is Senior Research Associate and Director, Program

for the Human Environment, The Rockefeller University,

New York, NY

BERNARD BALL is Associate in Research, Duke University, Durham, NC

ROBERT D. BALLARD is President, Ocean Exploration Trust; Director,

Center for Ocean Exploration, Graduate School of Oceanography,

University of Rhode Island; and President, Ocean Exploration

Center, Mystic Aquarium

W. BENJAMIN BALLARD is an undergraduate at Connecticut College,

New London, CT

JONATHAN BEAUDOIN was Research Assistant Professor, Center

for Coastal \& Ocean Mapping, University of New Hampshire,

Durham, $\mathrm{NH}$

KATHERINE L.C. BELL is Vice President and Chief Scientist, Ocean Exploration Trust, Lyme, CT

RICHARD BELL is Postdoctoral Fellow, National Research Council,

Northeast Fisheries Science Center, National Oceanic and

Atmospheric Administration, Narragansett, RI

SAMANTHA P. BERLET is a graduate student at Pennsylvania State University, State College, PA

RUTH BLAKE is Professor, Department of Geology and Geophysics,

Yale University, New Haven, CT

AMY BORGENS is State Marine Archaeologist, Texas Historical

Commission, Austin, TX

MICHAEL L. BRENNAN is Postdoctoral Researcher, Graduate School of Oceanography, University of Rhode Island, Narragansett, RI

STEPHEN BURKE is Associate Producer, Ocean Exploration Trust, Lyme, CT

FRANK CANTELAS is Archaeologist, Office of Ocean Exploration and Research, National Oceanic and Atmospheric Administration, Silver Spring, MD

KATHLEEN CANTNER is Science Illustrator, American Geosciences Institute, Alexandria, VA

ALICIA CAPORASO is Archaeologist, Bureau of Ocean Energy

Management, New Orleans, LA

ZENA CARDMAN is a graduate student at the University of North Carolina, Chapel Hill, NC

STEVEN CAREY is Professor, Graduate School of Oceanography, University of Rhode Island, Narragansett, RI

ROGER CHASTAIN is Staff Research Associate, Scripps Institution of Oceanography, San Diego, CA

JASON CHAYTOR is Research Geologist, Woods Hole Science Center, US Geological Survey, Woods Hole, MA
MICHAEL CHEADLE is Associate Professor, University of Wyoming, Laramie, WY

DWIGHT F. COLEMAN is Director, Inner Space Center, University of Rhode Island, Narragansett, RI

PATRICK CONNALLY is a graduate student in the School of the Environment, Florida A\&M University, Tallahassee, $\mathrm{FL}$

SHARON KATZ COOPER is Assistant Director, Deep Earth Academy, Consortium for Ocean Leadership, Washington, DC

JON COPLEY is Lecturer, National Oceanography Centre, University of Southampton, Southampton, UK

ERIK E. CORDES is Assistant Professor, Temple University, Philadelphia, PA

KELSEY CORNWELL is a graduate student at University College London, London UK

KATRINA CUBINA is Senior Vice President, Educational Programs, JASON Learning, Mystic, CT

RICHARD DANNENBERG is a graduate student at Pennsylvania State University, State College, PA

DAN DAVIS is Assistant Professor, Classical Archaeology, Luther College, Decorah, IA

JAMES DELGADO is Director, Maritime Heritage Program, Office of National Marine Sanctuaries, National Oceanic and Atmospheric Administration, Silver Spring, MD

AMANDA W.J. DEMOPOULOS is Research Benthic Ecologist, Southeast Ecological Science Center, US Geological Survey, Gainesville, FL

FREDERIC DONDIN is Research Fellow Volcanologist, Seismic Research Centre, University of the West Indies, St. Augustine, Trinidad \& Tobago

SARAH DUDUYER is an engineer in the Département Infrastructures Marines et Numériques, IFREMER, Plouzané, France

MUHAMMET DUMAN is Associate Professor, Institute of Marine Science and Technology, Dokuz Eylül University, Turkey

CARTER DUVAL is a graduate student at the University of Delaware, Newark, DE

DANIEL FAAS is an undergraduate at Luther College, Decorah, IA

CHRISTINA FANDEL is a recent graduate of the Center for Coastal \& Ocean Mapping, University of New Hampshire, Durham, NH

ANDREW T. FISHER is Professor, Earth and Planetary Sciences Department, University of California, Santa Cruz, CA

HENRI FLOC'H is an engineer in the Département Infrastructures Marines et Numériques, IFREMER, Plouzané, France

SARAH A. FULLER is a graduate student at the Graduate School of Oceanography, University of Rhode Island, Narragansett, RI

ALLISON FUNDIS is Director of Education, Ocean Exploration Trust, Lyme, CT

GRACIELA GARCIA-MOLINER is Habitat Specialist, Caribbean Fishery Management Council, National Oceanic and Atmospheric Administration, San Juan, Puerto Rico

SAMUEL GARSON is Education Programs Manager, Ocean Exploration Trust, Lyme, CT

TIMOTHY GATES is President, Gates Acoustic Services, Gaithersburg, MD 
SAMUEL E. GEORGIAN is a graduate student at Temple University, Philadelphia, PA

CHRIS GERMAN is Senior Scientist, Woods Hole Oceanographic Institution, Woods Hole, MA

STEVE GITTINGS is Science Coordinator, Office of National Marine Sanctuaries, National Oceanic and Atmospheric Administration, Silver Spring, MD

JUDITH GOBIN is Lecturer, Department of Life Sciences, University of the West Indies, St. Augustine, Trinidad \& Tobago

ETHAN GOLD is Director of Software \& Data Engineering, Ocean Exploration Trust, Lyme, CT

OMARI GRAHAM is a graduate student at Seismic Research Centre, University of the West Indies, St. Augustine, Trinidad \& Tobago

FREDERICK HANSELMANN is Research Faculty, Meadows Center for Water and the Environment, Texas State University, San Marcos, TX CHRISTOPHER HORRELL is Senior Archaeologist, Bureau of Safety and Environmental Enforcement, New Orleans, LA

JACK IRION is Supervisory Archaeologist, Bureau of Ocean Energy Management, New Orleans, LA

BARBARA JOHN is Professor, University of Wyoming, Laramie, WY PAUL JOHNSON is Data Manager, Center for Coastal \& Ocean

Mapping, University of New Hampshire, Durham, NH

WILLIAM KIENE is Associate Science Coordinator, Southeast Atlantic, Gulf of Mexico, and Caribbean Region, Office of National Marine Sanctuaries, National Oceanic and Atmospheric Administration, Silver Spring, MD

D. CALEB KING is a graduate student at the University of North Carolina, Chapel Hill, NC

ROBERT KNOTT is Senior Video Broadcast Engineer, Ocean Exploration Trust, Lyme, CT

YVES LE GALL is an engineer in the Département Infrastructures Marines et Numériques, IFREMER, Plouzané, France

DEAN LIVELYBROOKS is Senior Instructor, Department of Physics, University of Oregon, Eugene, OR

XAVIER LURTON is an engineer in the Département Infrastructures Marines et Numériques, IFREMER, Plouzané, France

LEIGH MARSH is a recent $\mathrm{PhD}$ recipient at National Oceanography Centre, University of Southampton, Southampton, UK

CATHERINE MARZIN is National Partnership Coordinator, Office of National Marine Sanctuaries, National Oceanic and Atmospheric Administration, Silver Spring, MD

DANIELLE L. McKEAN is an undergraduate at The Pennsylvania State University, State College, PA

MATHIEU MERCIER-GINGRAS is a graduate student at the University of Montreal, Montreal, Quebec, Canada

REUBEN MILLS is Director of ROV Operations, Ocean Exploration Trust, Lyme, CT

PATRICIA MILOSLAVICH is Associate Professor, Department of Environmental Studies, Universidad Simón Bolívar, Caracas, Venezuela

GREGORY MULDER is Professor, Department of Physical Sciences, Linn-Benton Community College, Albany, OR

SCOTT MUNRO is Executive Producer, Ocean Exploration Trust, Lyme, CT

ANNE PACAULT is an engineer in the Département Infrastructures Marines et Numériques, IFREMER, Plouzané, France
BRENNAN T. PHILLIPS is a graduate student at the Graduate School of Oceanography, University of Rhode Island, Narragansett, RI

SUSAN POULTON is Digital Media Consultant, Ocean Exploration Trust, Lyme, CT

NICOLE A. RAINEAULT is Postdoctoral Researcher, Graduate School of Oceanography, University of Rhode Island, Narragansett, RI

HANNAH RAMSINGH is a seismic/research technician at the Seismic Research Centre, University of the West Indies, St. Augustine, Trinidad \& Tobago

KATHERINE RODRIGUE is a research assistant at Graduate School of Oceanography, University of Rhode Island, Narragansett, RI

CHRISTOPHER ROMAN is Associate Professor, Graduate School of Oceanography, University of Rhode Island, Narragansett, RI

DANNISE RUIZ RAMOS is a graduate student at The Pennsylvania

State University, State College, PA

VAL SCHMIDT is Research Project Engineer, Center for Coastal \& Ocean Mapping, University of New Hampshire, Durham, NH

BRAD SEIBEL is Professor, Department of Biological Sciences, University of Rhode Island, Kingstown, RI

NAM SIU is a recent graduate of Western Washington University, Bellingham, WA

CLARA SMART is a graduate student in the Department of Ocean Engineering, University of Rhode Island, Kingstown, RI

ELIZABETH SMITH was Director of Communications, Ocean Exploration Trust, Lyme, CT

STEPHEN SPARKS is Professor, School of Earth Sciences, Bristol University, Bristol, UK

ADAM STINTON is Volcanologist, Montserrat Volcano Observatory, Flemmings, Montserrat, West Indies

URI TEN BRINK is Research Geophysicist and Senior Scientist, Woods Hole Science Center, US Geological Survey, Woods Hole, MA

DOUGLAS R. TOOMEY is Professor, Department of Geological Sciences, University of Oregon, Eugene, OR

ANNE M. TRÉHU is Professor, College of Earth, Ocean, and Atmospheric Science, Oregon State University, Corvallis, OR ARTHUR C. TREMBANIS is Associate Professor, College of Earth, Ocean, and Environment, University of Delaware, Newark, DE

TUFAN TURANLI is Project Manager, Ocean Exploration Trust, Bodrum, Turkey

CINDY VAN DOVER is Professor and Director, Duke University Marine Lab, Duke University, Durham, NC

MIKE VECCHIONE is Adjunct Scientist, National Systematics Lab, Northeast Fisheries Science Center, National Marine Fisheries Service, Washington, DC

TODD VIOLA is Nautilus Live Website Producer, Sea Research Foundation, Mystic, CT

CHRISTOPHE VRIGNAUD is an engineer at the Service Hydrographique et Océanographique de la Marine, Brest, France

JAMIE WAGNER is a graduate student a the Duke Marine Lab, Duke University, Durham, NC

KAREN WISHNER is Professor, Graduate School of Oceanography, University of Rhode Island, Narragansett, RI

MARISA YEARTA is an acoustic engineer at Gates Acoustic Services, Gaithersburg, MD

DANIELLE M. YOUNG is a graduate student at Temple University, Philadelphia, PA 


\section{ACKNOWLEDGEMENTS}

NAUTILUS EXPLORATION PROGRAM STAFF

- Robert D. Ballard ${ }^{82,38,94}$, OET President, GSO Professor, OEC President

- Katherine L.C. Bell ${ }^{82}$, Executive Vice President \& Chief Scientist

- Laurie Bradt ${ }^{82}$, Vice President, Business Affairs

- Michael L. Brennan ${ }^{38}$, Postdoctoral Researcher

- Stephen Burke ${ }^{82}$, Assistant Producer

- Dwight F. Coleman ${ }^{38}$, Director, Inner Space Center

- Allison Fundis ${ }^{82}$, Director, Education

- Samuel Garson ${ }^{82}$, Coordinator, Education Programs

- Ethan Gold ${ }^{82}$, Director, Software \& Data Engineering

- Ian Kulin ${ }^{82}$, Port Engineer

- Robert Knott ${ }^{82,94}$, Senior Video Engineer

- Janice Meagher ${ }^{82}$, Executive Assistant

- Reuben Mills ${ }^{82}$, Director, ROV Operations

- Scott Munro ${ }^{82}$, Executive Producer

- Angela Murphy ${ }^{83}$, Coordinator, Travel \& Logistics

- Nicole A. Raineault ${ }^{38}$, Postdoctoral Researcher

- Christopher Roman ${ }^{38}$, Director, Mapping \& Imaging Program

- Alexandra Witten ${ }^{82}$, Executive Director, Development \&

Special Programs

\section{NAUTILUS ADVISORY BOARD}

- James A. Austin Jr. ${ }^{130}$ • Jesse Ausubel ${ }^{109}$ • Ruth Blake ${ }^{138}$ • Steven Carey ${ }^{38}$

- Chris German ${ }^{136}$ • Stephen Hammond ${ }^{87}$ • Jeffrey Karson ${ }^{103}$

- Deborah Kelley ${ }^{132}$ • Larry Mayer ${ }^{22}$ • Michael Mottl ${ }^{121}$

- Timothy Shank ${ }^{136}$ • Cindy Van Dover ${ }^{31}$

\section{AT-SEA TEAM}

- Sulaiman Al-Sibani ${ }^{102}$ • Brian Andrews ${ }^{137}$ - Roy Armstrong ${ }^{128}$

- Jean-Mari Augustin ${ }^{44}$ • Jesse Ausubel ${ }^{109}$ • W. Benjamin Ballard ${ }^{25}$

- Robert D. Ballard ${ }^{82,38,94}$ • Emily Ballard ${ }^{110}$ • Laura Batt ${ }^{49}$

- Jonathan Beaudoin ${ }^{22}$ • Richard Bell ${ }^{77}$ • Katherine L.C. Bell ${ }^{82}$

- Giovani Benitez ${ }^{5}$ • Samantha Berlet ${ }^{89}$ • Andrew Billings ${ }^{136}$

- Amy Borgens ${ }^{106}$ • Michael L. Brennan ${ }^{38}$ - Stephen Burke ${ }^{82}$

- Richard Camilli ${ }^{136}$ - Frank Cantelas ${ }^{84}$ - Kathleen Cantner ${ }^{6}$

- Rabindranath Cantu-Fuguemann ${ }^{51}$ - Alicia Caporaso ${ }^{16}$

- Michael Cappetta ${ }^{5}$ Alexis Cardenas ${ }^{51}$ - Zena Cardman ${ }^{125}$

- Steven Carey ${ }^{38}$ • Roger Chastain ${ }^{93} \cdot$ Jason Chaytor ${ }^{137} \cdot$ Josh Chernov $^{82}$

- Dwight F. Coleman ${ }^{45}$ • Erik E. Cordes ${ }^{105}$ • Kelsey Cornwell ${ }^{115}$

- Margaret Craig ${ }^{129}$ - Katrina Cubina ${ }^{49}$ - Richard Dannenberg ${ }^{89}$

- Donald Dansereau ${ }^{8}$ - Dan Davis ${ }^{59}$ - Alex DeCiccio ${ }^{45}$

- James Delgado ${ }^{83}$ - Amanda Demopoulos ${ }^{99}$ - Mark DeRoche ${ }^{82}$

- Frederic Dondin ${ }^{95}$ - Sarah Duduyer ${ }^{44}$ • Alan Duester ${ }^{136}$

- Muhammet Duman ${ }^{46}$ - Michael Durbin ${ }^{82}$ • Carter DuVal ${ }^{19}$

- Christopher Englert ${ }^{22}$ • Daniel Faas ${ }^{59}$ - Christina Fandel ${ }^{22}$

- Michael Filimon ${ }^{129}$ • Henri Floc'h ${ }^{44}$ • Philip Forte ${ }^{136}$ • Justin Fujii ${ }^{136}$

- Sarah Fuller ${ }^{38}$ - Allison Fundis ${ }^{82} \cdot$ Rachel Gaines ${ }^{68}$

- Graciela Garcia-Moliner ${ }^{19}$ - Samuel Garson ${ }^{82}$ - Timothy Gates ${ }^{36}$

- Samuel Georgian ${ }^{105}$ • Judith Gobin ${ }^{131}$ • Ethan Gold ${ }^{82}$

- Stefani Gordon ${ }^{74}$ - Omari Graham ${ }^{95}$ - Todd Gregory ${ }^{82}$

- Frederick Hanselmann ${ }^{107}$ • Jared Harris ${ }^{52}$ • Charles Hohing ${ }^{52}$

- Christopher Horrell ${ }^{17}$ • Jonathan Howland ${ }^{136}$ • Jack Irion ${ }^{16}$

- Kevin Jerram ${ }^{22}$ - Arianna Johns ${ }^{134,60}$ • Paul Johnson ${ }^{22}$

- Kimberly Johnson ${ }^{28}$ • Frank Johnson ${ }^{28}$ • Carl Kaiser ${ }^{136}$ - Kathy Kasic ${ }^{74}$

- Alex Kavanaugh ${ }^{129}$ • Sean Kelley ${ }^{136} \cdot$ D. Caleb King ${ }^{125}$
- Robert Knott ${ }^{82,94}$ • Ian Kulin ${ }^{82}$ - Greg Kurras ${ }^{136} \cdot$ Zachary Lash $^{82}$ - Yves Le Gall ${ }^{44}$ - Stephen Licht ${ }^{129}$ - Nicholas Love ${ }^{35}$ - Xavier Lurton ${ }^{44}$

- Roderick MacLeod ${ }^{82} \cdot$ Leigh Marsh $^{76}$ • Eric Martin ${ }^{67}$

- Danielle McKean ${ }^{89}$ - Karl McLetchie ${ }^{82}$ • Janice Meagher ${ }^{94,82}$

- Reuben Mills ${ }^{82}$ - Zara Mirmalek ${ }^{40} \cdot$ Mary Nichols $^{64}$ • Matt Norenberg ${ }^{93}$

- Elizabeth Orcutt ${ }^{12}$ • Anne Pacault ${ }^{44} \cdot$ Mark Paton $^{90}$ • Emil Petruncio ${ }^{113}$

- Brennan Phillips ${ }^{38}$ • Oscar Pizarro ${ }^{8}$ Susan Poulton ${ }^{82}$

- Nicole A. Raineault ${ }^{38}$ • Hannah Ramsingh ${ }^{95}$ • Dushyant Rao

- Brian Raynes ${ }^{82}$ - Kathleen Ridgway ${ }^{82}$ • David Robillard ${ }^{113}$

- Kendolyn Roe ${ }^{104}$ - Deepti Rohatgi ${ }^{82}$ Christopher Roman ${ }^{38}$

- Dannise Ruiz Ramos ${ }^{89}$ • Allan Santos ${ }^{82} \cdot$ Val Schmidt $^{22} \cdot$ Brad Seibel $^{129}$

- Jamie Sherwood ${ }^{82} \cdot$ Jennifer Shoemaker $^{74}$ • Clara Smart ${ }^{129}$

- Elizabeth Smith ${ }^{82}$ - William Snyder ${ }^{129}$ - Steven Sparks ${ }^{14}$

- Scott Stamps ${ }^{82}$ • Adam Stinton ${ }^{69}$ • Uri ten Brink ${ }^{137}$

- Arthur Trembanis ${ }^{119}$ - Tufan Turanls ${ }^{82}$. Suna Tuzun ${ }^{82}$

- David Valentine ${ }^{117}$ - Cindy Van Dover ${ }^{31}$ - Shelby Van Hart ${ }^{104}$

- James Ian Vaughn ${ }^{129}$ • Christophe Vrignaud ${ }^{96}$ - Robert Waters ${ }^{136}$

- Shannon Weiss ${ }^{29} \cdot$ Kerry Whalen $^{82} \cdot$ Gabriel Whitston $^{61}$

- Tara Willis ${ }^{58}$ • Alexandra Witten ${ }^{82,129} \cdot$ Mary Woo $^{116} \cdot$ Marisa Yearta $^{36}$

- Dana Yoerger ${ }^{136}$ • Danielle Young ${ }^{105}$

\section{EXPLORATION NOW PRODUCTION TEAM \&} INNER SPACE CENTER STAFF

- Erin Bilbo ${ }^{45,129}$ • Tyler Blanpied ${ }^{45,129}$ - Chris Boylston ${ }^{82}$

- Kelsey Brown ${ }^{45,129}$ - Tim Burbank ${ }^{82}$ • Stephen Burke ${ }^{82} \cdot$ Kyle Calise $^{82,129}$

- Dwight F. Coleman ${ }^{45}$. Patrick Connally ${ }^{33}$ - Alex DeCiccio ${ }^{45}$

- James Duffy ${ }^{45,82,129}$ • Erick Geiger ${ }^{45}$ - Arianna Johns ${ }^{134,60}$

- Robert Knott ${ }^{82,94}$ • Chris Knowlton ${ }^{45} \cdot$ Daniel Larsh $^{82} \cdot$ David LePage $^{82}$

- Liz Miller ${ }^{82}$ - Kelly Moran ${ }^{82}$ • Holly Morin ${ }^{45}$ • Scott Munro ${ }^{82}$

- Ali Sandler ${ }^{82}$. Eileen Slavin ${ }^{82}$ • Clara Smart ${ }^{129} \cdot$ Derek Sutcliffe $^{45}$

- Tim Tierney ${ }^{82} \cdot$ Hunter Trowbridge ${ }^{45} \cdot$ Christian Williams $^{82}$

- Michelle Zitzmann ${ }^{45,129}$

\section{SCIENTISTS AND ARTISTS ASHORE}

- Runa $\mathrm{A}^{31}$ • Diva Amon ${ }^{76,79}$. Steven Auscavitch ${ }^{123}$ • Jesse Ausubel ${ }^{109}$

- Amy Baco-Taylor ${ }^{34} \cdot$ Bernard Ball $^{31}$ • Douglas Bartlett ${ }^{93} \cdot$ Richard Bell $^{77}$

- Katherine L.C. Bell ${ }^{82}$ • Amanda Berg ${ }^{31}$ • Ruth Blake ${ }^{138}$ • Jeff Book ${ }^{80}$

- Kathleen Cantner ${ }^{6}$. Jason Chaytor ${ }^{137} \cdot$ Michael Cheadle ${ }^{133}$

- Jon Copley ${ }^{76}$. Erik E. Cordes ${ }^{105}$ - Marie-Helene Cormier ${ }^{38}$

- Thaddeus Crist ${ }^{133}$ - Amanda Demopoulos ${ }^{99}$ - Matthew Dunlop III ${ }^{133}$

- Scott France ${ }^{122} \cdot$ Chris German $^{136} \cdot$ Steve Gittings ${ }^{83}$ • Austin Heller ${ }^{133}$

- Santiago Herrera ${ }^{136} \cdot$ Keith Ingledew $^{133} \cdot$ Barbara John $^{133}$

- Mandy Joye ${ }^{120}$ - Joshua Kelly ${ }^{72}$ William Kiene ${ }^{83} \cdot$ Justin LaForge $^{133}$

- Lisa Levin ${ }^{93}$ - Connor Marr ${ }^{133}$ • Catherine Marzin ${ }^{83}$

- Martha Nizinski ${ }^{78}$ - Rose Pettiette ${ }^{133}$. Brennan T. Phillips ${ }^{38}$

- Andrea Polanco ${ }^{47}$ - Shirley Pomponi ${ }^{39}$ - Nancy Prouty ${ }^{88}$

- Andrea Quattrini ${ }^{105}$ • Nicole A. Raineault ${ }^{38}$ • Timothy Shank ${ }^{136}$

- Roderick Stewart ${ }^{69}$ - Masako Tominaga ${ }^{66}$ - Cindy Van Dover ${ }^{31}$

- Mike Vecchione ${ }^{78} \cdot$ Les Watling $^{121} \cdot$ Karen Wishner $^{38} \cdot$ John Zupanic ${ }^{133}$

\section{EDUCATION, OUTREACH, \& COMMUNICATIONS TEAM}

- Laura Batt ${ }^{49}$ - Laurie Bradt ${ }^{82}$ - Stephen Burke ${ }^{83}$ - Katrina Cubina ${ }^{49}$

- Kelsey Flora ${ }^{74}$ - Allison Fundis ${ }^{82}$ - Samuel Garson ${ }^{82}$ - Frederic Gorell ${ }^{84}$

- Brian Kennedy ${ }^{84}$ - Todd McLeish ${ }^{129}$ • Barbara Moffet ${ }^{74}$ • Scott Munro ${ }^{82}$

- Amy Ochs ${ }^{11}$ - Susan Poulton ${ }^{82}$ • Patrick Shea ${ }^{49}$ • Eleanor Smalley ${ }^{49}$

- Elizabeth Smith ${ }^{82}$ • Alejandra Villarreal ${ }^{11}$ • Todd Viola ${ }^{94,82}$

- Shannon Weiss ${ }^{29}$ - Alexandra Witten ${ }^{82,129}$ • Andy Wood ${ }^{94}$ - Jim Zebora ${ }^{94}$ 


\section{HONORS RESEARCH PROGRAM STUDENTS}

- Ryan Baldwin ${ }^{108}$ • Consuelo Barton ${ }^{56}$ - Daniel Cryan ${ }^{54}$

- Shannon Emrich ${ }^{81} \cdot$ D. Nakoa Farrant ${ }^{50} \cdot$ Nathanael Lane $e^{30}$

- Sebastian Martinez ${ }^{70}$ • Shannon O’Connor ${ }^{53}$. Russell Parker ${ }^{110}$

- Katelyn Schneider ${ }^{18}$ • Catherine Valery ${ }^{111}$ • Elizabeth Vanderwall ${ }^{62}$

\section{SCIENCE AND ENGINEERING INTERNS}

- Steven Auscavitch ${ }^{123}$ • Adele Bennett ${ }^{127}$ • Aaron Chesler ${ }^{101}$

- Patrick Connally ${ }^{33}$ - Stephen Estrin ${ }^{58}$ • Alan Franks ${ }^{66}$ - Hilary Hudson ${ }^{66}$

- Renato Kane ${ }^{119}$ - Michael Marin ${ }^{58,60}$ • C. Alex Martin ${ }^{92}$

- Catherine McCaughey ${ }^{129}$ - Mathieu Mercier-Gingras ${ }^{124}$

- Katherine Rodrigue ${ }^{38} \cdot \mathrm{Nam} \mathrm{Siu}^{135} \cdot$ Michael Smith $^{129} \cdot$ Jamie Wagner $^{31}$

\section{STEM COMMUNICATION FELLOWS}

- Gillian Ashenfelter ${ }^{56}$ - Stella Barth ${ }^{110}$ • Lauren Bello ${ }^{55}$ Megan Cook $^{65}$

- Cindy Duguay $^{91} \cdot$ Brian Facemire $^{18} \cdot$ Stacy Gale ${ }^{88}$ • Burnham Hall ${ }^{11}$

- Susan Heaney ${ }^{112}$ • Steven Hosking ${ }^{110}$ • Alejandra Martinez ${ }^{32,37}$

- Patricia Miloslavich ${ }^{114}$ • Martin Momsen ${ }^{43}$ • Jason Pittman ${ }^{41}$

- Hannah Prior ${ }^{97}$ Tiffany Risch ${ }^{27}$ - Michael Romano ${ }^{1}$ - Aundrea Rue $e^{20}$

- Bethany Smith ${ }^{23} \cdot$ Noelle Turner ${ }^{10} \cdot$ Lisa Wu ${ }^{111}$

\section{JASON ARGONAUTS}

- Erica Fonetenot ${ }^{9}$ - Catherine Ann Gale ${ }^{42}$ Samuel Gonsoulin ${ }^{100}$

- Ankush Joshi ${ }^{24}$ • Jacques Jougla ${ }^{27}$ • Paloma June ${ }^{100}$ • Dejon King ${ }^{3}$

- Excel Luna ${ }^{4}$ Austin Sanderson ${ }^{98}$ • Laura Smith ${ }^{2}$ • Ryan Sweat ${ }^{3}$

- Christopher Taylor ${ }^{13} \cdot$ R. Seaborn Wren ${ }^{7,73}$

\section{NAUTILUS CREW AND MARITIME MANAGEMENT}

- Peter Barry ${ }^{75}$ - Stephen Barry ${ }^{75}$ • Mykhailo Bespechnyi ${ }^{61}$

- Anatoliy Chamata ${ }^{61}$ - Fedir Chepoy ${ }^{61}$ - Volodymyr Chubar ${ }^{61}$

- Pavel Chubar ${ }^{61}$ • Phoebe Gilday ${ }^{15}$ • Viktor Khmelnychenko ${ }^{61}$

- Oleksiy Kokorin ${ }^{61}$ • Yuriy Malchenko ${ }^{61}$ - Sergiy Mazur ${ }^{61}$

- Dmytro Polovoy ${ }^{61}$ - Stefanie Schehrer ${ }^{61}$ Sergiy Semenov ${ }^{61}$

- Dmytro Serbin ${ }^{61}$ • Igor Sergiienko ${ }^{61} \cdot$ Sergiy Sheremet $^{61}$

- Maksym Shybistyi ${ }^{61}$ - Sergiy Simchenko ${ }^{61}$ • Bohdan Sklyar ${ }^{61}$

- Kelly Stoerman ${ }^{61} \cdot$ Niall Toner $^{48} \cdot$ John Toner $^{61} \cdot$ Sergii Tsyganenko ${ }^{61}$

- Fedir Uzun ${ }^{61}$ • Vitalii Verbyts'kyi ${ }^{61}$

\section{EXPLORATION NOW PARTNERS}

- Aquarium of the Pacific, Long Beach, CA

- Exploratorium, San Francisco, CA

- Houston Museum of Nature \& Science, Houston, TX

- Mystic Aquarium, Mystic, CT

- Texas State Aquarium, Corpus Christi, TX

- Titanic Belfast Museum, Belfast, Northern Ireland

\section{MAJOR PARTNERS \& SPONSORS}

- Bechtel

- CSA Ocean Sciences

- ECOGIG Consortium

- ExxonMobil Foundation

- Graduate School of Oceanography, University of Rhode Island

- Jason Learning

- Meadows Center for the Environment, Texas State University

- National Geographic Society

- Ocean Exploration Trust Directors \& Sponsors

- Office of Naval Research

- Office of Ocean Exploration \& Research,

National Oceanic and Atmospheric Administration

- Sea Research Foundation

\section{AFFILIATIONS}

1 Acton-Boxborough Regional High School, Acton, MA

2 Albright Middle School, Alief Independent School District, Houston, TX

3 Aldine Independent School District, Houston, TX

4 Alief Independent School District, Houston, TX

5 American Broadcasting Company, New York, NY

6 American Geosciences Institute, Alexandria, VA

7 Augusta Preparatory Day School, Martinez, GA

8 Australian Centre for Field Robotics, University of Sydney, Sydney, Australia

9 Bayou Chico Elementary School, Evangeline Parish, Ville Platte, LA

10 Bearden High School, Knoxville, TN

11 Bechtel, San Francisco, CA

12 Bigelow Laboratory for Ocean Sciences, Boothbay, ME

13 Boise School District, Boise, ID

14 Bristol University, Bristol, UK

15 British Columbia Institute of Technology, Burnaby, Canada

16 Bureau of Ocean Energy Management, New Orleans, LA

17 Bureau of Safety and Environmental Enforcement, New Orleans, LA

18 Cape Henry Collegiate School, Virginia Beach, VA

19 Caribbean Fishery Management Council, National Oceanic and Atmospheric Administration, San Juan, Puerto Rico

20 Carolina Forest High School, Myrtle Beach, SC

21 Carpinteria High School, Carpinteria, CA

22 Center for Coastal \& Ocean Mapping, University of New Hampshire, Durham, NH

23 Chesapeake Bay Governor's School for Marine \& Environmental Science, Warsaw, VA

24 Congressional Schools of Virginia, Falls Church, VA

25 Connecticut College, New London, CT

26 Consortium for Ocean Leadership, Washington, DC

27 Coventry High School, Coventry, RI

28 CSA Ocean Sciences, Houston, TX

29 David Heil \& Associates, Inc., Portland, OR

30 Deerfield Academy, Deerfield, MA

31 Duke University, Durham, NC

32 Eagle Pass Independent School District, Eagle Pass, TX

33 Florida A\&M University, Tallahassee, FL

34 Florida State University, Tallahassee, FL

35 G.S.E Rentals Ltd, Aberdeen, Scotland, UK

36 Gates Acoustic Services, Gaithersburg, MD

37 GeoFORCE, Jackson School of Geosciences, University of Texas at Austin, Austin, TX

38 Graduate School of Oceanography, University of Rhode Island, Narragansett, RI

39 Harbor Branch Oceanographic Institute, Florida Atlantic University, Fort Pierce, FL

40 Harvard University, Cambridge, MA

41 Hollin Meadows Science and Math Focus School, Alexandria, VA

42 Holy Trinity Catholic School, Grapevine, TX

43 Houston High School, Houston, MN

44 IFREMER, Plouzané, France

45 Inner Space Center, University of Rhode Island, Narragansett, RI

46 Institute of Marine Science and Technology, Dokuz Eylül University, Turkey

47 INVEMAR Marine and Coastal Research Institute, Santa Marta, Colombia

48 Ireland Institute of Art, Design, and Technology, Dublin, Ireland

49 JASON Learning, Mystic, CT 
50 Kapalama High School, Honolulu, HI

51 Kongsberg Maritime, Kongsberg, Norway

52 Kongsberg Underwater Technology, Inc., Lynnwood, WA

53 L \& N STEM Academy, Knoxville, TN

54 La Salle Academy, Providence, RI

55 Liberty Middle School, Fairfax, VA

56 Lick-Wilmerding High School, San Francisco, CA

57 Linn-Benton Community College, Albany, Oregon

58 Long Beach City College, Long Beach, CA

59 Luther College, Decorah, IA

60 Marine Advanced Technology Education Center, Monterey, CA

61 Maritime Management, Wicklow, Ireland

62 Mercer Island High School, Mercer Island, WA

63 Michigan State University, East Lansing, MI

64 Middle Tennessee State University, Murfreesboro, TN

65 Mission Blue, San Francisco, CA

66 Montana State University, Bozeman, MT

67 Monterey Bay Aquarium Research Institute, Monterey, CA

68 Monterey Peninsula College, Monterey, CA

69 Montserrat Volcano Observatory, Flemmings, Montserrat, West Indies

70 Mount Rainier High School, Des Moines, WA

71 Mystic Aquarium, Mystic, CT

72 National Aeronautics and Space Administration, Washington, DC

73 National Eagle Scout Association, Boy Scouts of America, Irving, TX

74 National Geographic Society, Washington, DC

75 National Maritime College of Ireland, Ringaskiddy, Cork, Ireland

76 National Oceanography Centre, University of Southampton, Southampton, UK

77 National Research Council, Northeast Fisheries Science Center, National Oceanic and Atmospheric Administration, Narragansett, RI

78 National Systematics Lab, Northeast Fisheries Science Center, National Marine Fisheries Service, Washington, DC

79 Natural History Museum, London, UK

80 Naval Research Laboratory, Washington, DC

81 North Kingstown High School, N. Kingstown, RI

82 Ocean Exploration Trust, Lyme, CT

83 Office of National Marine Sanctuaries, National Oceanic and Atmospheric Administration, Silver Spring, MD

84 Office of Ocean Exploration and Research, National Oceanic and Atmospheric Administration, Silver Spring, MD

85 Oregon State University, Corvallis, OR

86 Pacific Coastal and Marine Science Center, U.S. Geological Survey, Santa Cruz, CA

87 Pacific Marine Environmental Laboratory, National Oceanic and Atmospheric Administration, Newport, OR

88 Paul Cuffee School, Providence, RI

89 Pennsylvania State University, State College, PA

90 QPS Canada Inc., Fredericton, New Brunswick, Canada

91 Regional School Unit \#52, Turner, ME

92 Rochester Institute of Technology, Rochester, NY

93 Scripps Institution of Oceanography, University of California, San Diego, San Diego, CA

94 Sea Research Foundation, Mystic, CT

95 Seismic Research Centre, University of the West Indies, St. Augustine, Trinidad \& Tobago
96 Service Hydrographique et Océanographique de la Marine, Brest, France

97 Sir Peter Blake Trust, Auckland, NZ

98 Smithfield School District, Smithfield, RI

99 Southeast Ecological Science Center, US Geological Survey, Gainesville, FL

100 Spring Branch Independent School District, Houston, TX

101 St Lawrence University, Canton, NY

102 Sultanate of Oman

103 Syracuse University, Syracuse, NY

104 Tabor Academy, Marion, MA

105 Temple University, Philadelphia, PA

106 Texas Historical Commission, Austin, TX

107 Texas State University, San Marcos, TX

108 The Kinkaid School, Houston, TX

109 The Rockefeller University, New York, NY

110 The Williams School, New London, CT

111 Thomas Jefferson High School for Science \& Technology, Alexandria, VA

112 Titanic Belfast Museum, Belfast, N. Ireland

113 US Naval Academy, Annapolis, MD

114 Universidad Simón Bolívar, Caracas, Venezuela

115 University College London, London, UK

116 University of California Irvine, Irvine, CA

117 University of California Santa Barbara, Santa Barbara, CA

118 University of California Santa Cruz, Santa Cruz, CA

119 University of Delaware, Newark, DE

120 University of Georgia, Athens, GA

121 University of Hawaii at Manoa, Honolulu, HI

122 University of Louisiana at Lafayette, Lafayette, LA

123 University of Maine, Orono, ME

124 University of Montreal, Montreal, Quebec, Canada

125 University of North Carolina, Chapel Hill, NC

126 University of Oregon, Eugene, OR

127 University of Otago, North Dunedin, NZ

128 University of Puerto Rico at Mayagüez, Mayagüez, Puerto Rico

129 University of Rhode Island, Kingstown, RI

130 University of Texas at Austin, Austin, TX

131 University of the West Indies, St. Augustine, Trinidad \& Tobago

132 University of Washington, Seattle, WA

133 University of Wyoming, Laramie, WY

134 University-National Oceanographic Laboratory System, Narragansett, RI

135 Western Washington University, Bellingham, WA

136 Woods Hole Oceanographic Institution, Woods Hole, MA

137 Woods Hole Science Center, US Geological Survey, Woods Hole, MA

138 Yale University, New Haven, CT

The authors would like to thank the governments of the Cayman Islands British Overseas Territory, Commonwealth of Puerto Rico, Montserrat British Overseas Territory, Commonwealth of Dominica, French Republic, Grenada, Republic of Turkey, and United States of America. 


\section{REFERENCES}

Barkan, R., and U. ten Brink. 2010. Tsunami simulations of the 1867 Virgin Islands earthquake: Constraints on epicenter location and fault parameters. Bulletin of the Seismological Society of America 100:995-1,009, http:// dx.doi.org/10.1785/0120090211.

Bouysse, P., J. Baubron, M. Richard, R. Maur, and P. Andreieff. 1985. Evolution de la terminaison nord de l'arc interne des Petites Antilles au PlioQuaternaire. Bulletin de la Société Géologique de France 1:181-188.

Brennan, M.L., R.D. Ballard, C. Roman, K.L. Croff Bell, B. Buxton, D.F. Coleman, G. Inglis, O. Koyagasioglu, and T. Turanlı. 2012. Evaluation of the modern submarine landscape off southwestern Turkey through the documentation of ancient shipwreck sites. Continental Shelf Research 43:55-70, http://dx.doi.org/10.1016/j.csr.2012.04.017.

Carey, S., P. Nomikou, K. Croff Bell, M. Lilley, J. Lupton, C. Roman, E. Stathopoulou, K. Bejelou, and R. Ballard. 2013. $\mathrm{CO}_{2}$ degassing from hydrothermal vents at Kolumbo submarine volcano, Greece, and the accumulation of acidic crater water. Geology 41:1,035-1,038, http://dx.doi.org/10.1130/G34286.1.

Cassidy, M., J. Trofimovs, M.J. Palmer, P.J. Talling, S.F.L. Watt, S.G. Moreton, and R.A. Taylor. 2013. Timing and emplacement dynamics of newly recognised mass flow deposits at $\sim 8-12$ ka offshore Soufrière Hills volcano, Montserrat: How submarine stratigraphy can complement subaerial eruption histories. Journal of Volcanology and Geothermal Research 253:1-14, http://dx.doi.org/10.1016/j.jvolgeores.2012.12.002.

Clinton, J.F., G. Cua, V. Huérfano, C.G. von Hillebrandt-Andrade, and J.M. Cruzado. 2006. The current state of seismic monitoring in Puerto Rico. Seismological Research Letters 77:532-543, http://dx.doi.org/10.1785/gssrl.77.5.532.

Cordes, E.E., D.C. Bergquist, and C.R. Fisher. 2009. Macro-ecology of Gulf of Mexico cold seeps. Annual Review of Marine Science 1:143-168, http://dx.doi.org/10.1146/annurev.marine.010908.163912.

Deplus, C., A. Le Friant, G. Boudon, J.C. Komorowski, B. Villemant, C. Harfod, J. Segoufin, and J.L. Cheminee. 2001. Submarine evidence for large-scale debris avalanches in the Lesser Antilles arc. Earth and Planetary Science Letters 192:145-157, http://dx.doi.org/10.1016/ S0012-821X(01)00444-7.

Devine, J., and H. Sigurdsson. 1995. Petrology and eruption styles of Kick'em Jenny submarine volcano, Lesser Antilles island arc. Journal of Volcanology and Geothermal Research 69:35-58, http://dx.doi.org/10.1016/0377-0273(95)00025-9.

Dondin F., J.-F. Lebrun, K. Kelfoun, N. Fournier, and A. Randrianasolo. 2012. Sector collapse at Kick'em Jenny submarine volcano (Lesser Antilles): Numerical simulation and landslide behavior. Bulletin of Volcanology 74:595-607, http://dx.doi.org/10.1007/s00445-011-0554-0.

Fisher, A.T., J. Cowen, C.G. Wheat, and J.F. Clark. 2011a. Preparation and injection of fluid tracers during IODP Expedition 327, eastern flank of Juan de Fuca Ridge. In Proceedings, IODP, 327. A.T. Fisher, T. Tsuji, and K. Petronotis, eds, Integrated Ocean Drilling Program Management International, Tokyo, Japan, http://dx.doi.org/10.2204/iodp.proc. 327.108.2011.

Fisher, A.T., T. Tsuki, K. Petronotis, C.G. Wheat, K. Becker, J.F. Clark, J. Cowen, K. Edwards, H. Jannasch, and the IODP Expedition 327 and Atlantis Expedition AT18-07 Shipboard Parties. 2012. IODP Expedition 327 and Atlantis Expedition AT18-07: Observatories and experiments on the eastern flank of the Juan de Fuca Ridge. Scientific Drilling 13:4-11, http://dx.doi.org/10.2204/iodp.sd.13.01.2011.
Fisher, A.T., C.G. Wheat, K. Becker, J. Cowen, B. Orcutt, S. Hulme, K. Inderbitzen, A. Turner, T. Pettigrew, E.E. Davis, and others. $2011 \mathrm{~b}$. Design, deployment, and status of borehole observatory systems used for single-hole and cross-hole experiments, IODP Expedition 327, eastern flank of the Juan de Fuca Ridge. In Proceedings, IODP, 327. A.T. Fisher, T. Tsuji, and K. Petronotis, eds, Integrated Ocean Drilling Program Management International, Tokyo, Japan, http://dx.doi.org/10.2204/ iodp.proc.327.107.2011.

German, C.R., A. Bowen, M.L. Coleman, D.L. Honig, J.A. Huber, M.V. Jakuba, J.C. Kinsey, M.D. Kurz, S. Leroy, J.M. McDermott, and others. 2010. Diverse styles of submarine venting on the ultraslow spreading Mid-Cayman Rise. Proceedings of the National Academy of Sciences of the United States of America 107:14,020-14,025, http://dx.doi.org/10.1073/ pnas.1009205107.

German, C.R., P.A. Tyler, C. McIntyre, D. Amon, M. Cheadle, J. Clarke, B. John, J. McDermott, S. Bennett, J. Huber, and others. 2012. Exploration of the Mid-Cayman Rise. Oceanography 25(1)suppl:52-53, http://tos.org/oceanography/archive/25-1_supplement.pdf.

Graff, J.R., J.A. Blake, and K.F. Wishner. 2008. A new species of Malacoceros (Polychaeta: Spionidae) from the hydrothermally active crater of Kick'em Jenny, a submarine volcano in the Lesser Antilles Arc (Caribbean Sea). Journal of the Marine Biological Association of the UK. 88:925-930, http://dx.doi.org/10.1017/S0025315408001884.

Hsing, P.-Y., B. Fu, E.A. Larcom, S.P. Berlet, T.M. Shank, A.F. Govindarajan, A.J. Lukasiewicz, P.M. Dixon, and C.R. Fisher. 2013. Evidence of lasting impact of the Deepwater Horizon oil spill on a deep Gulf of Mexico coral community. Elementa, http://dx.doi.org/10.12952/journal. elementa.000012.

Lebas, E., A. Le Friant, G. Boudon, S.F.L. Watt, P.J. Talling, N. Feuillet, C. Deplus, C. Berndt, and M.E. Vardy. 2011. Multiple widespread landslides during the long-term evolution of a volcanic island: Insights from high-resolution seismic data, Montserrat, Lesser Antilles. Geochemistry, Geophysics, Geosystems 12, Q05006, http://dx.doi.org/ 10.1029/2010GC003451.

Le Friant, A., C.L. Harford, C. Deplus, G. Boudon, R.S.J. Sparks, R.A. Herd, and J.C. Komorowski. 2004. Geomorphological evolution of Montserrat (West Indies): Importance of flank collapse and erosional processes. Journal of the Geological Society 161:147-160, http://dx.doi.org/10.1144/0016-764903-017.

Lindsay, J.M., J.B. Shepherd, and D. Wilson. 2005. Volcanic and scientific activity at Kick 'em Jenny submarine volcano 2001-2002: Implications for volcanic hazards in the Southern Grenadines, Lesser Antilles. Natural Hazards 34:1-24, http://dx.doi.org/10.1007/s11069-004-1566-2.

Lopez-Venegas, A.M., U.S. ten Brink, and E.L. Geist. 2008. Submarine landslide as the source for the October 11, 1918 Mona Passage tsunami: Observations and modeling. Marine Geology 254:35-46, http://dx.doi.org/10.1016/j.margeo.2008.05.001.

MacDonald, I.R., J.F. Reilly, S.E. Best, R. Venkataramaiah, R. Sassen, N.L. Guinasso, and J. Amos. 1993. Remote sensing inventory of active oil seeps and chemosynthetic communities in the northern Gulf of Mexico. Pp. 27-37 in Hydrocarbon Migration and Its Near-Surface Expression. D. Schumacher and M.A. Abrams, eds, AAPG Memoir 66.

Mercado, A., and W. McCann. 1998. Numerical simulation of the 1918 Puerto Rico tsunami. Natural Hazards 18:57-76, http://dx.doi.org/ 10.1023/A:1008091910209. 
Montagna, P.A., J.G. Baguley, C. Cooksey, I. Hartwell, L.J. Hyde, J.L. Hyland, R.D. Kalke, L.M. Kracker, M. Reuscher, and A.C.E. Rhodes. 2013. Deep-sea benthic footprint of the Deepwater Horizon blowout. PLoS ONE 8:e70540, http://dx.doi.org/10.1371/journal.pone.0070540.

National Research Council (NRC). 2003. Oil in the Sea III: Inputs, Fates, and Effects. The National Academies Press, Washington, DC, 280 pp.

Quattrini, A.M., P.J. Etnoyer, C.L. Doughty, L. English, R. Falco, N. Remon, M. Rittinghouse, and E.E. Cordes. 2013. A phylogenetic approach to octocoral community structure in the deep Gulf of Mexico. Deep Sea Research Part II, http://dx.doi.org/10.1016/j.dsr2.2013.05.027.

Roman, C., G. Inglis, I. Vaughn, C. Smart, D. Dansereau, D. Bongiorno, M. Johnson-Roberson, and M. Bryson. 2013. New tools and methods for precision seafloor mapping. Oceanography 26(1)suppl:10-15, http://tos.org/oceanography/archive/26-1_nautilus.pdf.

Roman, C., G. Inglis, J.I. Vaughn, C. Smart, B. Douillard, and S. Williams. 2012. The development of high-resolution sea-floor mapping techniques. Oceanography 25(1)suppl:42-45, http://tos.org/oceanography/ archive/25-1_supplement.pdf.

Smart, C., C. Roman, and S. Carey. 2013. Detection of diffuse seafloor venting using structured light imaging. Geochemistry, Geophysics, Geosystems 14:4,742-4,757, http://dx.doi.org/10.1002/ggge.20280.

Southwell, M.W., J.B. Weisz, C.S. Martens, and N. Lindquist. 2008. In situ fluxes of dissolved inorganic nitrogen from the sponge community on Conch Reef, Key Largo, Florida. Limnology and Oceanography 53:986-996, http://dx.doi.org/10.4319/lo.2008.53.3.0986. ten Brink, U.S., W.H. Bakun, and C.H. Flores. 2011. Historical perspective on seismic hazard to Hispaniola and the northeast Caribbean region. Journal of Geophysical Research 116, B12318, http://dx.doi.org/ 10.1029/2011JB008497.

Trofimovs, J., L. Amy, G. Boudon, C. Deplus, E. Doyle, N. Fournier, M.B. Hart, J.C. Komorowski, A. Le Friant, E.J. Lock, and others. 2006. Submarine pyroclastic deposits formed at the Soufrière Hills Volcano, Montserrat (1995-2003): What happens when pyroclastic flows enter the ocean? Geology 34:549-552, http://dx.doi.org/10.1130/G22424.1.

Wadge, G., R. Herd, G. Ryan, E.S. Calder, and J.-C. Komorowski. 2010. Lava production at Soufrière Hills Volcano, Montserrat: 19952009. Geophysical Research Letters 37, L00E03, http://dx.doi.org/ 10.1029/2009GL041466.

Wadge, G., R.E.A. Robertson, and B. Voight, eds. In press. The Eruption of Soufrière Hills Volcano, Montserrat from 2000 to 2010. Geological Society of London Memoir.

White, H.K., P.Y. Hsing, W. Cho, T.M. Shank, E.E. Cordes, A.M. Quattrini, R.K. Nelson, R. Camilli, A. Demopoulos, C.R. German, and others. 2012. Impact of the Deepwater Horizon oil spill on a deep-water coral community in the Gulf of Mexico. Proceedings of the National Academy of Sciences of the United States of America 109:20,303-20,308, http://dx.doi. org/10.1073/pnas.1118029109.

Wishner, K., J. Graff, J. Martin, S. Carey, H. Sigurdsson, and B. Seibel. 2005. Are midwater shrimp trapped in the craters of submarine volcanoes by hydrothermal venting? Deep Sea Research Part I 52:1,528-1,535, http://dx.doi.org/10.1016/j.dsr.2005.03.012. 


\section{Credits}

Support for this publication is provided by the Ocean Exploration Trust. All images are copyright " .

Ocean Exploration Trust unless otherwise noted.

○ 2014 The Oceanography Society

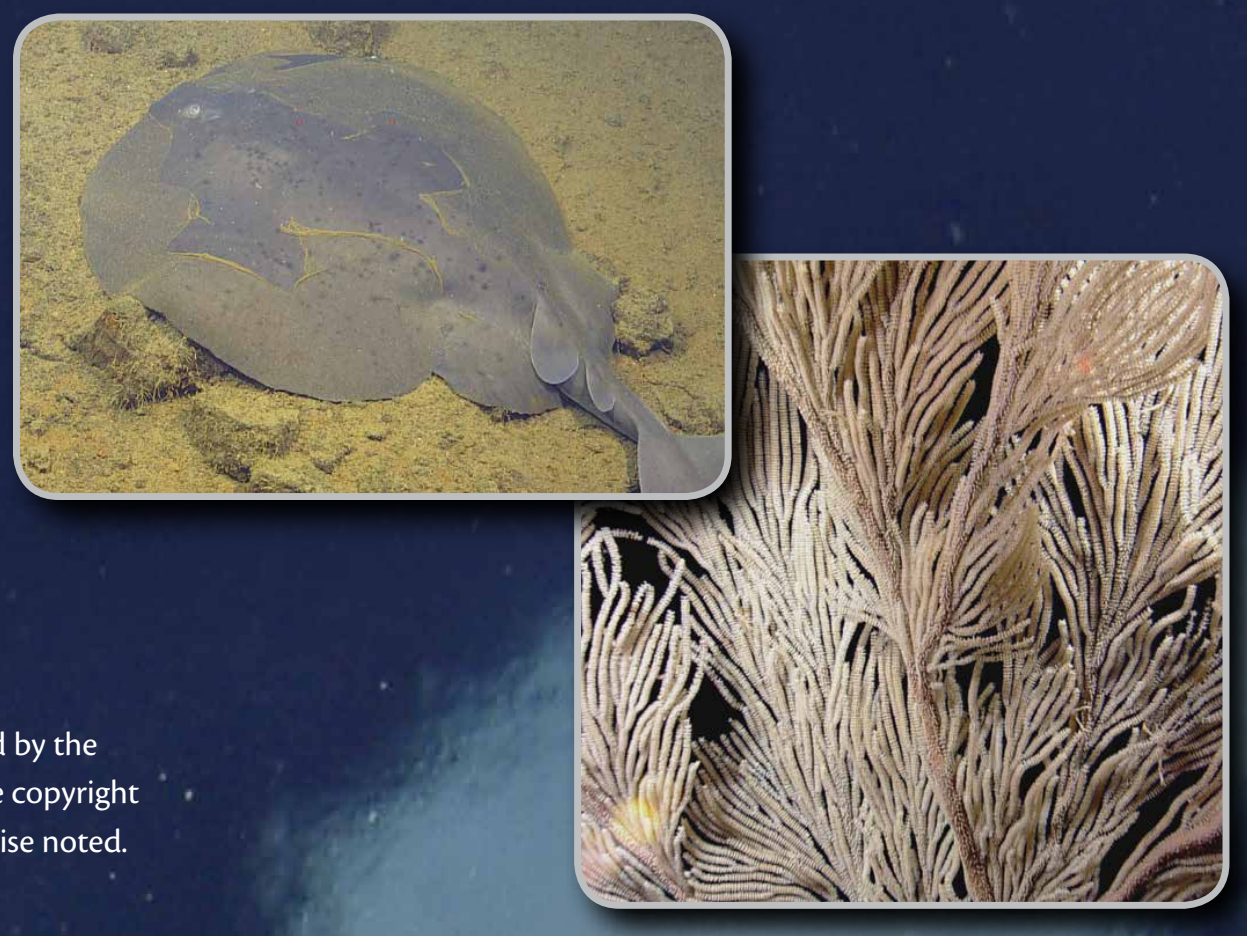

Editor: Ellen Kappel

Assistant Editor: Vicky Cullen

Layout and Design: Johanna Adams

Permission is granted to reprint in whole or in part for any noncommercial, educational uses. The Oceanography Society requests that the original source be credited.

Single printed copies are available upon request from info@tos.org. 
